\title{
Transposição didática e social: depoimentos e fotografias $^{1}$
}

\author{
Didactic and social transposition: reports and pics \\ Transposition didactique et sociale: témoignages et \\ photografies
}

Nilce da SILVA

\begin{abstract}
RESUMO
O presente material é fruto da coordenação de dois "espaços de criação", que funcionaram durante o primeiro semestre de 2008 pelo período de 60 horas cada um. Nestes "espaços", professores da rede pública e particular da cidade de São Paulo e alunos da Faculdade de Educação/ Universidade de São Paulo estudaram as principais características do mundo lusófono e, depois deste estudo, por meio de transposição didática, "eles ensinaram o que aprenderam a alunos da educação infantil e básica". Tal processo é agora apresentado por meio de uma série de depoimentos escritos, bem como, por um álbum fotográfico que contem material acerca dos usos da Língua Portuguesa na cidade de São Paulo e das relações sociais e raciais existentes na referida localidade, ambos produzidos por nossos colaboradores.
\end{abstract}

Palavras-chave: Espaço de Criação, Relações Sociais e Raciais, Transposição Didática, Mundo Lusófono, São Paulo.

\section{ABSTRACT}

This material is the result of the coordination of two "spaces of creation" that had functioned during the first semester of 2008, for the period of 60 hours each one. In these "spaces", teachers of public and private schools from Sao Paulo City and students of Faculty of Education/

\footnotetext{
${ }^{1}$ Este material não pode ser enquadrado em nenhum dos gêneros textuais que temos publicado neste periódico eletrônico. Mesmo assim, pedimos a compreensão de nossos leitores e colaboradores, tendo em vista a importância que o mesmo tem para que possamos atender aos objetivos propostos pelos seguintes projetos, apoiados pelo CNPq: Resgate da memória social e o papel da Revista Acolhendo a Alfabetização nos Países de Língua Portuguesa como suporte prático-teórico em favor da Lei 10639/03 (Edital PróAfrica) e Espaço de Criação: Uma Alternativa Educacional para Alunos em Situação de Exclusão Social e Escolar na Cidade de São Paulo (Edital Universal ).

${ }^{2}$ Para maiores informações acerca do conceito de "espaço de criação", procurar obras de D. W. Winnicott, Jean Biarnès, Nilce da Silva.
} 
University of Sao Paulo had studied the main characteristics of the Lusophone World and, after this study, by means of didactic transposition, they had taught what they had learned to students in kindergarten and in basic school. Such process now is presented in a series of reports, as well as, by a photographic album that were constructed by our collaborators. Both material are about the uses of the Portuguese Language in Sao Paulo City and social and racial relations in the related locality.

Index terms: "Space of Creation", Social and Racial Relations, Didactic Transposition, Lusophone World, Sao Paulo.

\section{RÉSUMÉ}

Ce matériel est le fruit de la coordination de deux « espaces de création » qui ont été mis en place au cours du premier semestre de 2008 avec une période de 60 heures/chaque. Dans ces « espaces », les enseignants des écoles publiques et privées de la ville de São Paulo et les élèves de la Faculté d'Éducation de l'Université de São Paulo ont étudié les caractéristiques principales du monde lusophone et, après cette étude, au moyen de transposition didactique, "ils ont enseigné ce qu'ils avaient appris aux élèves de l'éducation maternelle et élémentaire ». Ce processus est maintenant présenté au moyen d'une série d'articles, ainsi qu'un album photographique contenant le matériel explicatif de l'utilisation de la Langue Portugaise dans la ville de São Paulo et des relations sociales et ethniques existantes dans cette ville, les deux travaux ont été faits par nos collaborateurs.

Mots-clés: "Espace de Création", Relations Sociales et Ethniques, Transposition Didactique, Monde Lusophone, São Paulo.

\section{Introdução}

Este álbum fotográfico, assim como os depoimentos que fazem parte do n. 6 desta Revista, retratam aspectos importantes da cidade de São Pauloé resultado do Projeto: Resgate da memória social e o papel da Revista Acolhendo a Alfabetização nos Países de Língua Portuguesa como suporte prático-teórico em favor da Lei 10639/03 e do Projeto Espaço de Criação: Uma Alternativa Educacional para Alunos em Situação de Exclusão Social e Escolar na Cidade de São Paulo. 
Sendo assim, é fruto do trabalho de formação de dois "espaços de criação" utilizados por professores da rede pública e particular da cidade de São Paulo e de alunos de graduação da Universidade de São Paulo. Os mesmos foram desenvolvidos e coordenados pela professora doutora Nilce da Silva.

Tais "espaços" pretenderam oferecer subsídios prático-teóricos para a viabilidade de da lei A Lei 10639/03 que altera Lei 9394/96 de Diretrizes e Bases da Educação Nacional e estabelece obrigatoriedade do Ensino de História e Cultura Afro-Brasileira e Africana na Educação Básica e o Parecer $\mathrm{N}^{\circ}$ 1/04 do CNE que estabelece as Diretrizes Curriculares das Relações Étnico-Raciais.

Os "espaços de criação", cujo funcionamento foi de, em torno de 60 horas de fevereiro de 2008 a junho do mesmo ano, cada um, aqui designados como A e B, eram formados, em março de 2008, da seguinte maneira:

\section{ESPAÇOA}

32 mulheres e dois homens

28 pessoas abaixo de 30 anos; seis pessoas acima de 30 anos

Oito pessoas com renda média familiar abaixo de cinco salários mínimos, e os demais, acima desta faixa.

\section{ESPAÇO B}

22 mulheres e três homens

19 pessoas abaixo de 30 anos; seis pessoas acima desta idade. 
Cinco pessoas com renda familiar mensal até cinco salários mínimos, e os demais, acima desta faixa

Nestes espaços, desenvolvemos os seguintes temas: a) Aspectos gerais da colonização portuguesa; um panorama acerca dos processos de libertação dos países com Língua oficial Portuguesa. b) A relação entre língua materna e Língua Portuguesa no âmbito da alfabetização em Língua Portuguesa. c) O "mundo oficial lusófono" e as parecerias de colaboração bi(multi)latral. d) Bilinguismo/ multilinguismo / policulturalismo/ multiculturalismo: o ensino e a aprendizagem da Língua Portuguesa, à resistência à Língua Oficial. e) A relação entre linguagem e identidade; f) Literatura dos países com língua oficial portuguesa. d) Alfabetização bi(multi)lingue. e) A Lei 10.639 de 2003 e a formação de alfabetizadores. Deste modo, as relações estabelecidas entre "língua materna" e "língua oficial" no âmbito do ensino e da aprendizagem da alfabetização em Língua Portuguesa em países que a tem como oficial, na medida em que são antigas colônias portuguesas, dirigindo especial atenção a Moçambique.

Os conceitos de colonização, lusofonia, cultura, etnia, língua materna, língua oficial, língua veicular, identidade, fracasso escolar, resistência à aprendizagem da língua, entre outros, foram importantes neste contexto de formação.

Tivemos com objetivos- ao construir este álbum, assim como ao promover a escrita destes depoimentos acerca da transposição didática feita por nossos colaborabores- analisar como as fronteiras raciais e étnicas dialogam em termos da formação em serviço oferecida aos professores no âmbito desta pesquisa e a prática dos mesmos em sala de aula e discutir o mito da igualdade racial difundido na sociedade brasileira já que os usuários dos referidos "espaços de criação" colaboraram conosco na realização deste projeto ao levarem para muitas salas de aulas, da educação infantil e do 
ensino básico, os temas estudados no âmbito dos referidos espaços de formação. Assim, tanto a possibilidade de transposição didática para a implementação da Lei 10.639 de 2003 na ação pedagógica em sala de aula pode ser percebido por meio da leitura dos depoimentos que aqui apresentaremos, como a transposição de saberes- para além da sala de aulaestá registrado por meio da realização de fotografias que indicam um "novo" olhar sobre as relações sociais e raciais existentes na cidade de São Paulo. Acerca desta experiência, cabe destacar ainda que:

- Os usuários dos respectivos "espaços de criação" atingiram, em torno de 800 crianças que passaram a conhecer, ainda que minimamente, aspectos do mundo lusófono.

- Destas 800 crianças, $99 \%$ se mostraram satisfeitas durante o ensino de aspectos das culturas afro-brasileira e africanas dos países que têm a língua portuguesa como oficial.

- $\quad 80 \%$ das crianças atendidas são alunos de escolas públicas da cidade de São Paulo.

- Em torno de $85 \%$ das crianças atendidas mostraram não conhecer o assunto tratado em sala de aula por nossos colaboradores.

- Ainda que uma pequena porcentagem, em torno de 5\% das escolas participantes, não permitiu que assuntos referentes ao continente africano fossem abordados em suas instituições.

- $85 \%$ dos nossos colaboradores entendem que as "transposições didáticas" - que duravam, em média, de duas a três horas em sala de aula- realizadas poderiam se transformar em um curso- com mais tempo de estudo- acerca das culturas afro-brasileiras e africanas para as crianças atendidas. 
- Do conteúdo estudado nos "espaços de criação", as seguintes palavras-chave $^{3}$ foram utilizadas tanto nos planejamentos de aula como nas transposições didáticas em si, sendo que as apresentamos abaixo das usadas mais frequentemente, para as menos usadas ${ }^{4}$ :

“África"- "Brasil”- "Portugal”- "Colonização", "Escravo", "Língua Portuguesa", "Lusofonia"- "Negro"- "Pobreza"- "Cultura", "Identidade", "Etnia”, “Grupos Etnolinguísticos"- "Preconceito", "Racismo"- "Alfabetização", "Literatura"- "Moçambique", "Multuculturalismo", "Policulturalismo"- "Preto", "Pardo", "Mulato", "Selvagem"- "Língua Materna"- "Angola"- "Guiné-Bissau”- "TimorLeste"- "Cabo Verde"- "Macau", "Goa", "São Tomé e Príncipe""Latino", "Cucaracha"- "Diversidade", "Respeito", "Igualdade""Criolo", "Negão", "Neguinha", "Cor de Pele", "Pele cor-de-rosa", "Região Norte e Nordeste do Brasil", "Animais", "Divisões Políticas"- "Analfabetismo", "Guerra Civil", "Moreno", "Branquela", "Macaco" (gente), "Outras".

Feitas estas considerações, passemos ao material construído.

Sendo assim, passemos ao material:

Parte I: Álbum fotográfico divididos em:

A: Fotos das transposições didáticas desenvolvidas.

B: Fotos acerca das relações raciais e sociais na cidade de São Paulo.

C: Fotos acerca do uso da Língua Portuguesa na cidade de São Paulo.

${ }^{3}$ As palavras que apresentamos são consideradas "chave", pois a partir delas parte do conteúdo estudado nos "espaços de criação" poderiam ser trabalhados nas classes de educação infantil ou ensino básico.

${ }^{4}$ As palavras separadas por vírgulas foram usadas na mesma freqüência. 
Parte II: Depoimentos dos participantes dos "espaços de criação" em que relatam desde o momento da escola em que iriam apresentar seus conhecimentos adquiridos, o planejamento da transposição didática, este processo em si, a receptividade de professores e alunos das escolas públicas e privadas em que atuaram e, finalmente, suas considerações finais.

\section{PARTE I: ÁLBUM FOTOGRÁFICO 5}

\section{A: Fotos das transposições didáticas desenvolvidas}

\section{FOTOS- BLOCO 1}

Créditos: Carolline Ribeiro Lacerda, Manoela Ribeiro Paixão e Mirna Colazingari Barboza

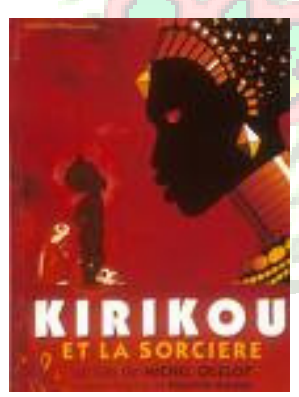

Capa do filme utilizado em atividade didática sobre culturas africanas.

- Direção: Michel Ocelot,

- $\quad$ Ano: 1998.

- $\quad$ Produção européia (Franca, Bélgica e Luxemburgo);

- Colorida,

\footnotetext{
${ }^{5}$ Não apresentaremos aqui, nem nas demais partes deste álbum, todo o material fotográfico coletado, já que boa parte dele continha fotos de pessoas e preferimos preservar o anonimato dos envolvidos no processo.
} 
- $\quad 71$ minutos.

- $\quad$ Edição: Dominique Lefèvre;

- $\quad$ Fotografia: Alain Levent.

- $\quad$ Música: Youssou N’Dour

Desenhos de aldeias africanas feitos por alunos do Ensino Fundamental

Créditos: Carolline Ribeiro Lacerda, Manoela Ribeiiro Paixão e Mirna Colazingari Barboa.
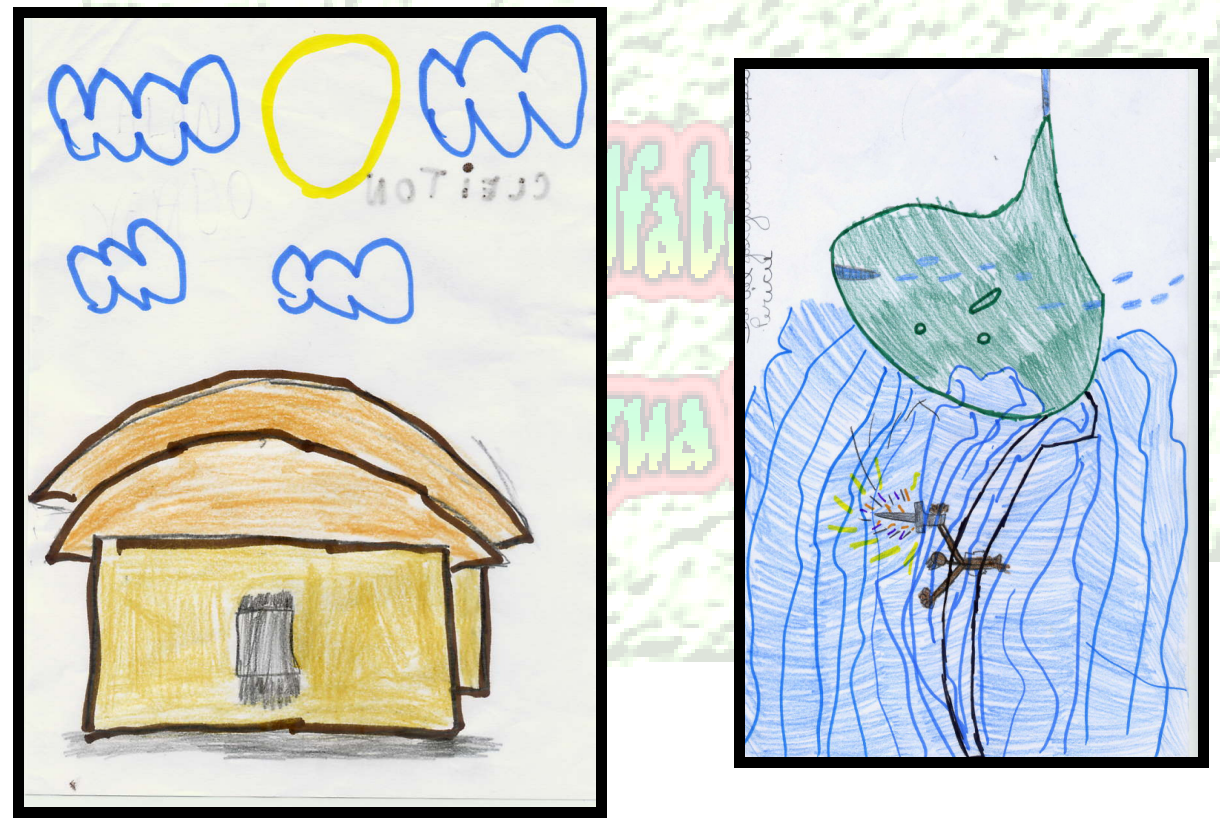


\section{FOTOS- BLOCO 2}

Créditos: Raíssa Chapaz

\section{Timor Leste}

Frutos do cafeeiro numa moeda de 50 centavos

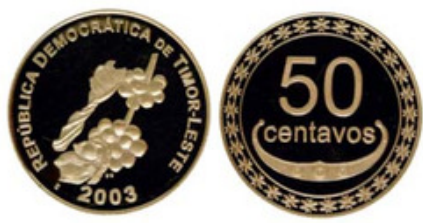

de 2003

Fonte: http://pt.wikipedia.org/wiki/Timor-

Leste. Acessado em: 16 de março
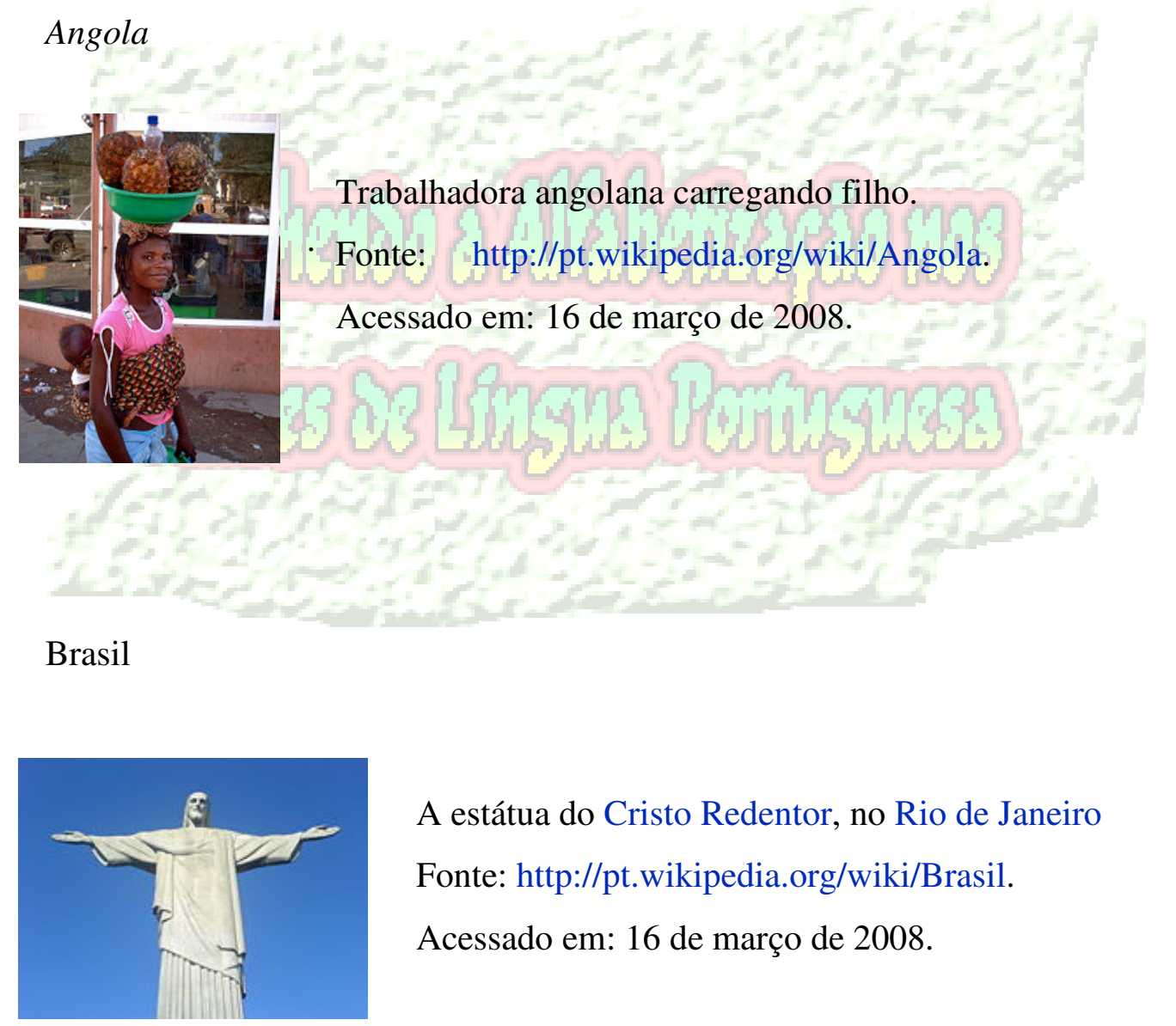

A estátua do Cristo Redentor, no Rio de Janeiro

Fonte: http://pt.wikipedia.org/wiki/Brasil.

Acessado em: 16 de março de 2008. 


\section{Moçanbique}

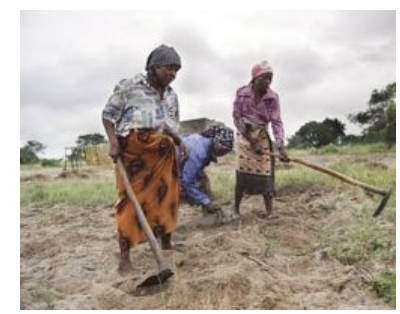

Mulheres moçambicanas a trabalhar na agricultura.

Fonte: http://pt.wikipedia.org/wiki/Mo\%C3\%A7ambique.

Acessado em: 16 de março de 2008

\section{Macau}

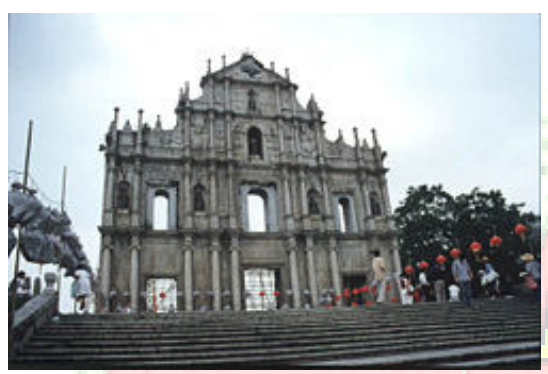

Ruínas de São Paulo, um dos monumentos mais famosos do Centro Histórico de Macau.

Fontes: http://pt.wikipedia.org/wiki/Macau.

Acessado em: 16 de março de 2008

Goa

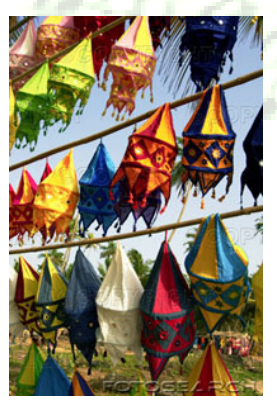

Artesanato

Fonte:

http://www.fotosearch.com.br/DGV041/200403262-

001/. Acessado em 16 de março de 2008 
São Tomé e Príncipe

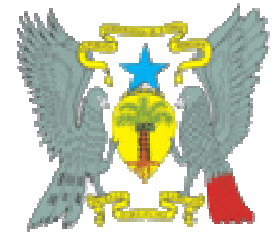

Brasão de São Tomé e Príncipe

Fonte:

http://pt.wikipedia.org/wiki/S\%C3\%A3o_Tom\%C3\%A 9_e_Pr\%C3\%ADncipe. Acessado em: 16 de março de 2008.

\section{Guiné-Bissau}

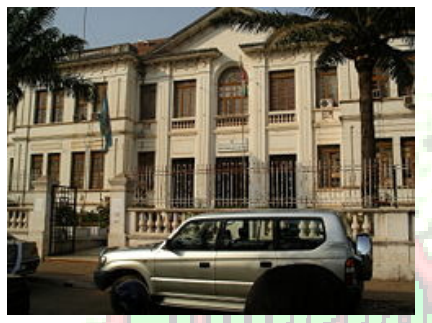

Ministério da Justiça

Fonte: http://pt.wikipedia.org/wiki/Guin\%C3\%A9-

Bissau. Acessado em: 16 de março de 2008

\section{Cabo Verde}

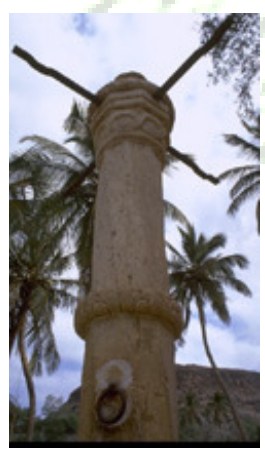

Pelourinho da Cidade Velha,

próxima a Praia, na Ilha de Santiago

Fonte: http://pt.wikipedia.org/wiki/Cabo_Verde.

Acessado em: 16 de março de 2008 


\section{FOTOS: BLOCO 3}

Créditos: Patrícia Vincenzi e Thatiane Kaufman
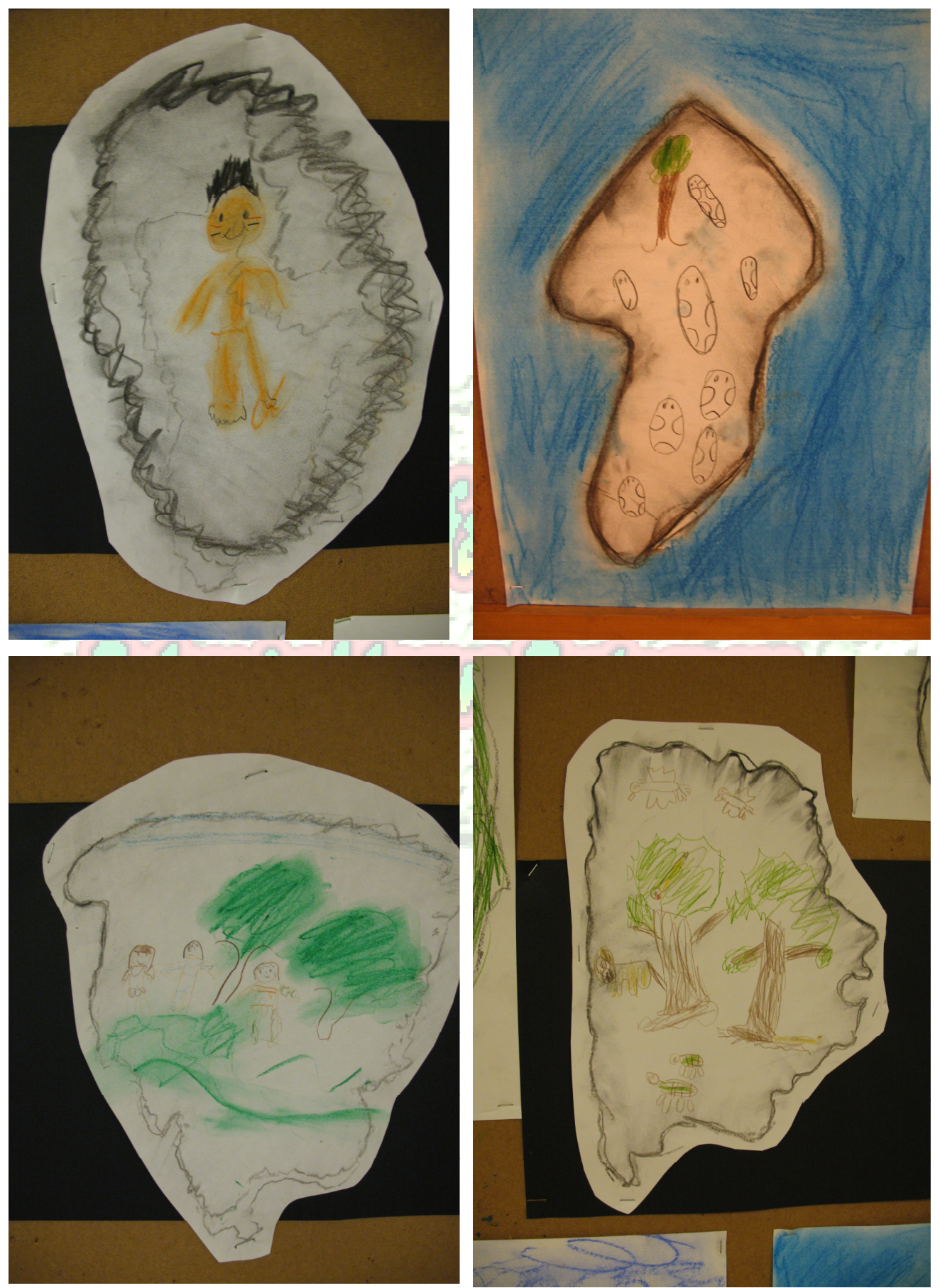
Expressão artística de alunos de educação infantil sobre conhecimento prévio acerca do continente africano

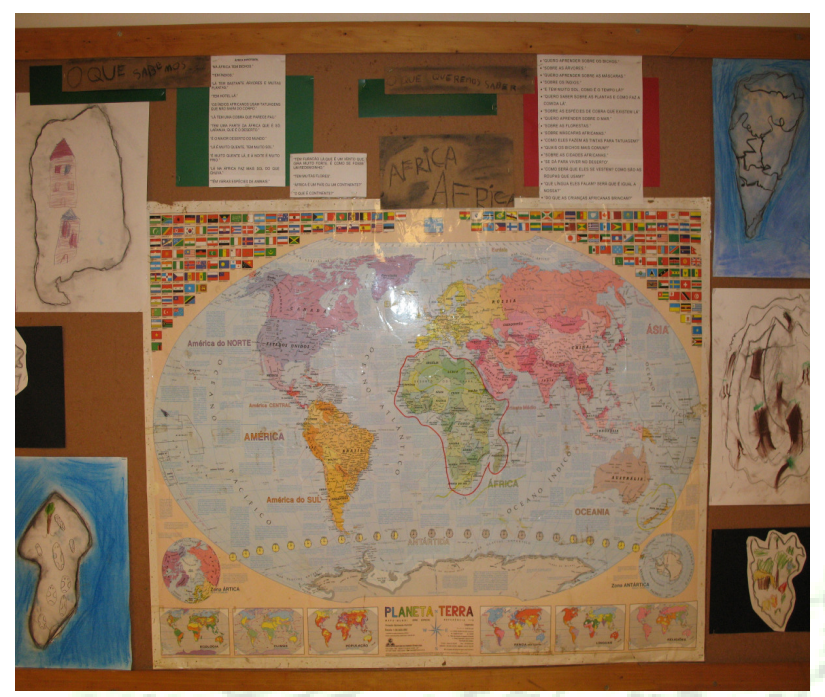

Planisfério usado em sala de aula. Continente africano em destaque.
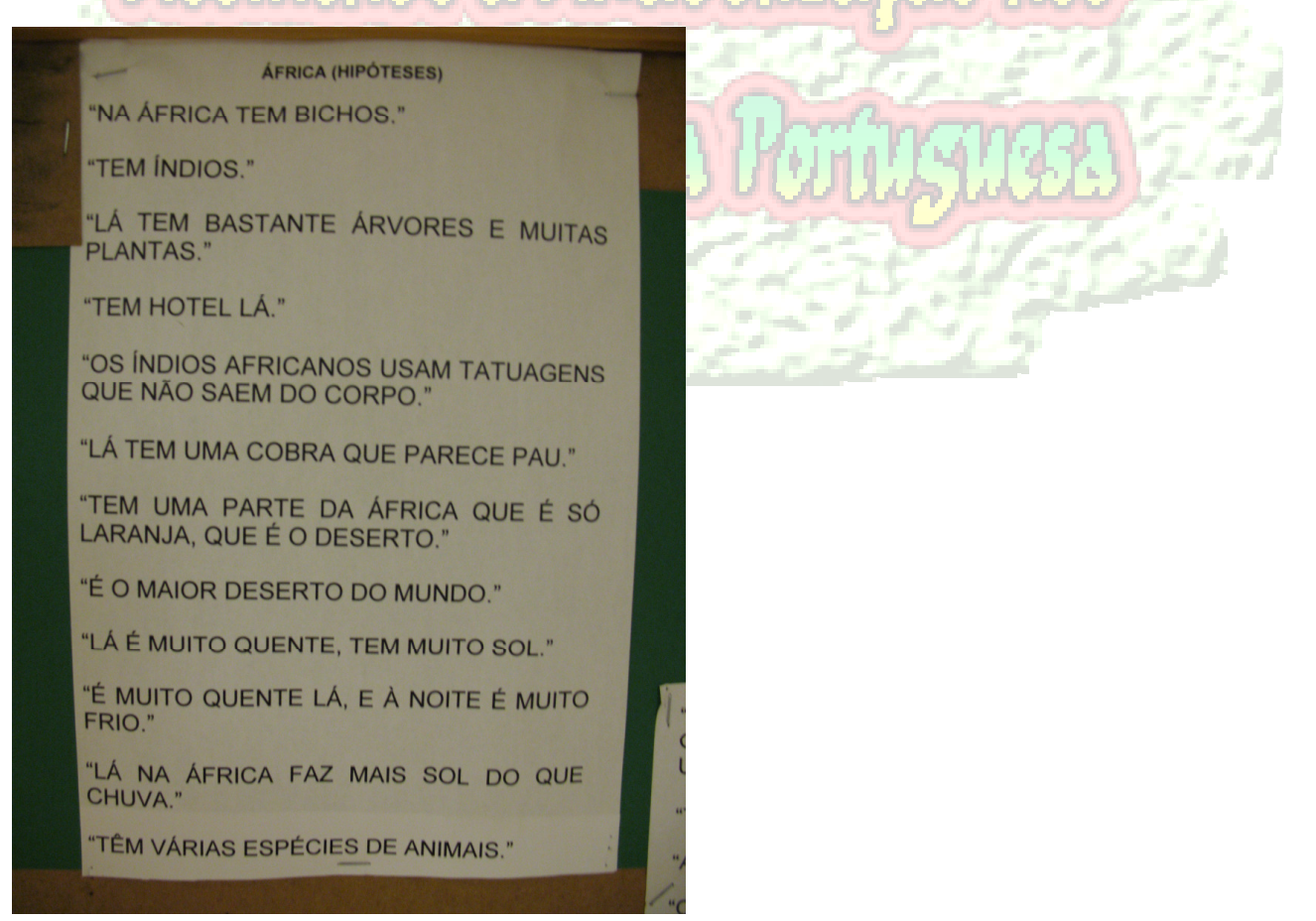

Hipóteses levantadas pelas crianças sobre África 


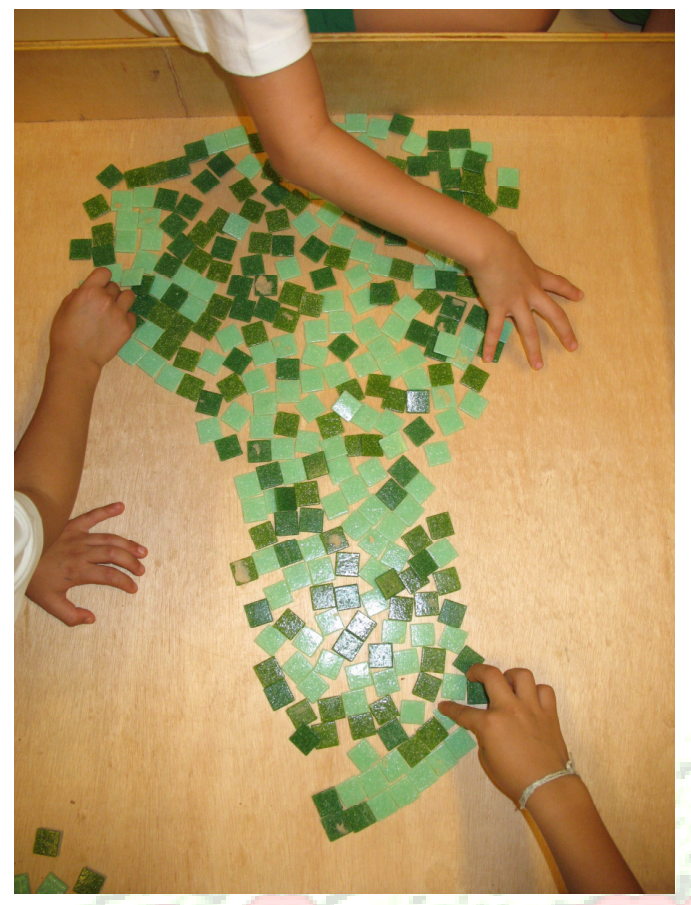

Construção de tabuleiro de jogo, forma: continente africano.
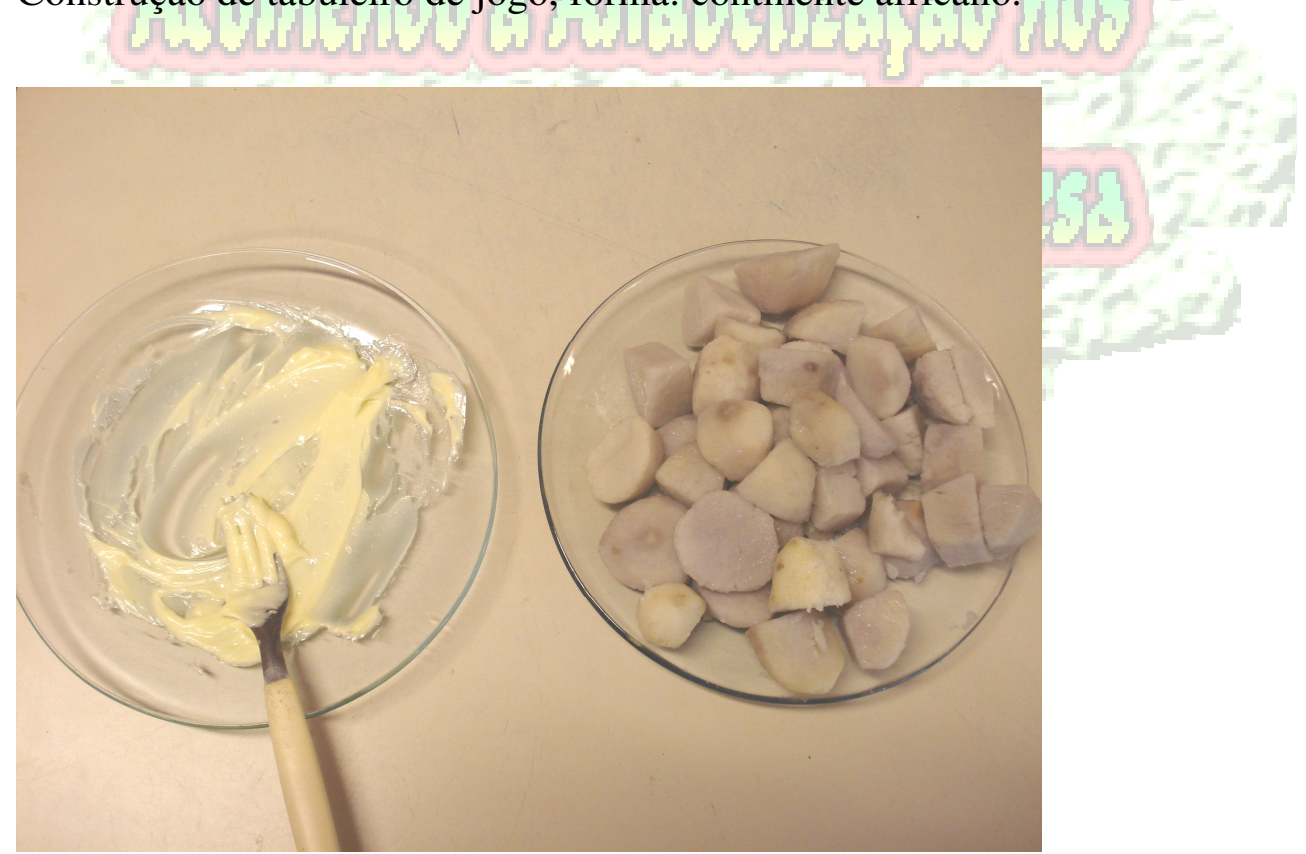

Inhame com manteiga feito em sala de aula com os alunos de Educação Infantil 


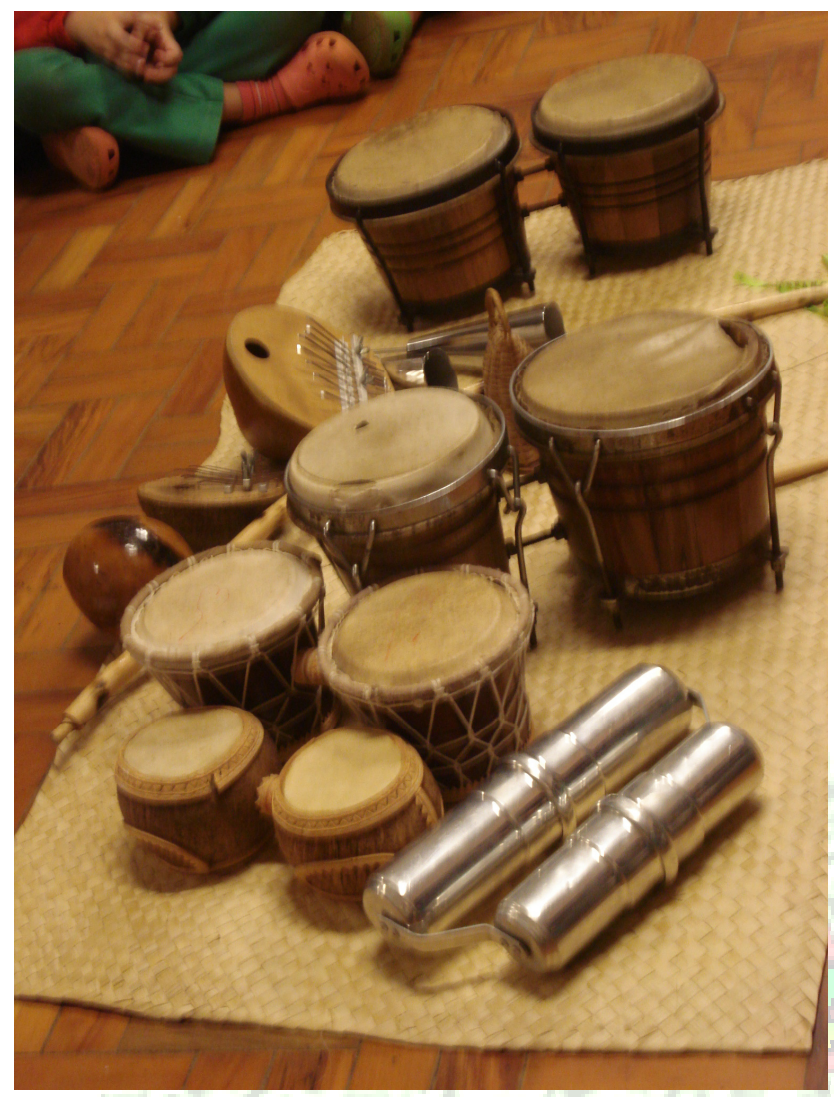

Instrumentos africanos usados em sala de aula

\section{FOTOS: BLOCO 5}

Créditos: Débora Thais Sales dos Santos

Fernanda Moretti Ferrari

Mônica Cassiano da Silva

Taize Alves Santana

Leitura e escrita numa perspectiva educativa: animais do Pantanal 

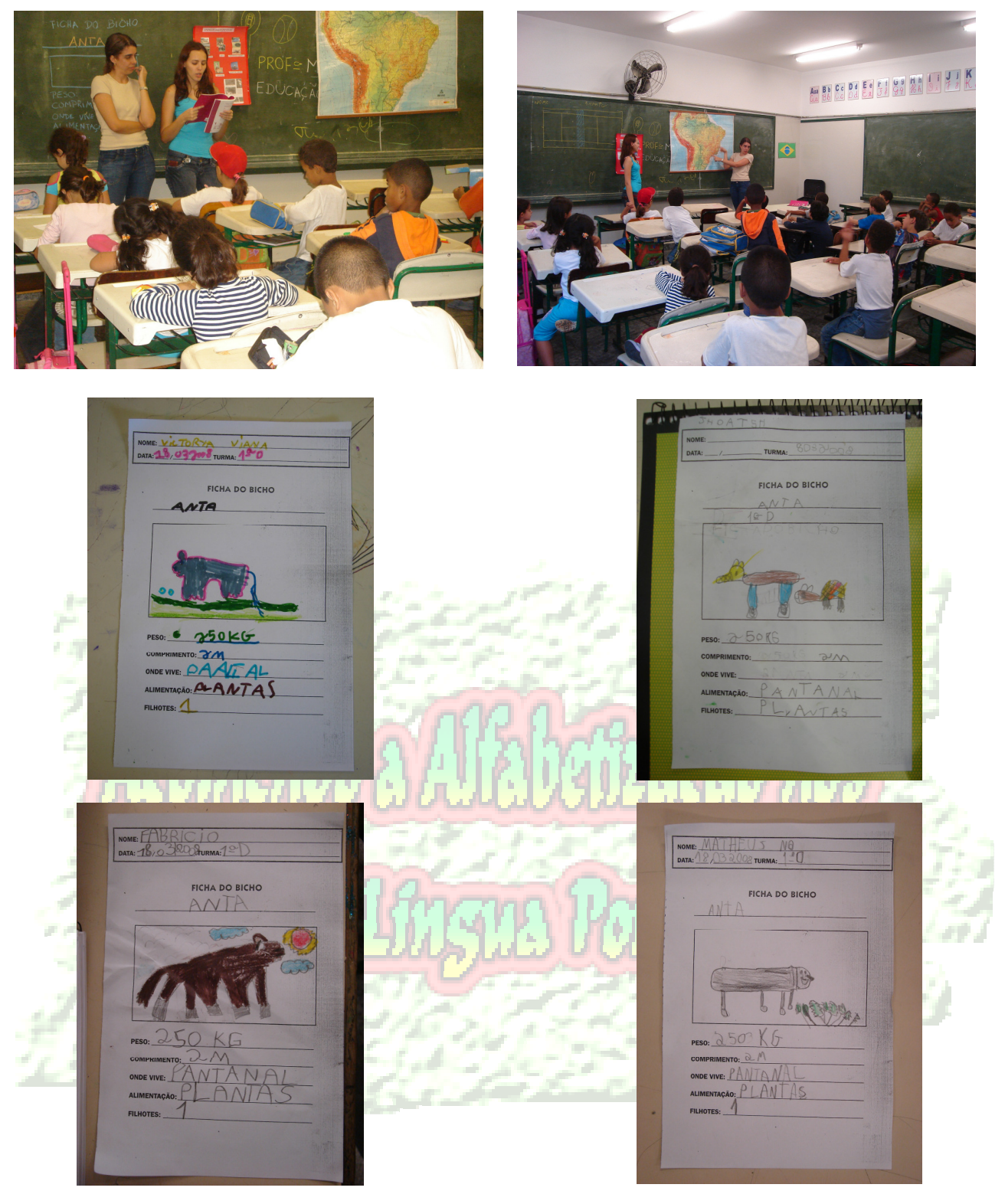


\section{FOTOS- BLOCO 6}

Créditos: Anita Cohn e Júlia Cravo

Fotos da sala de aula em que foi realizada a transposição didática.

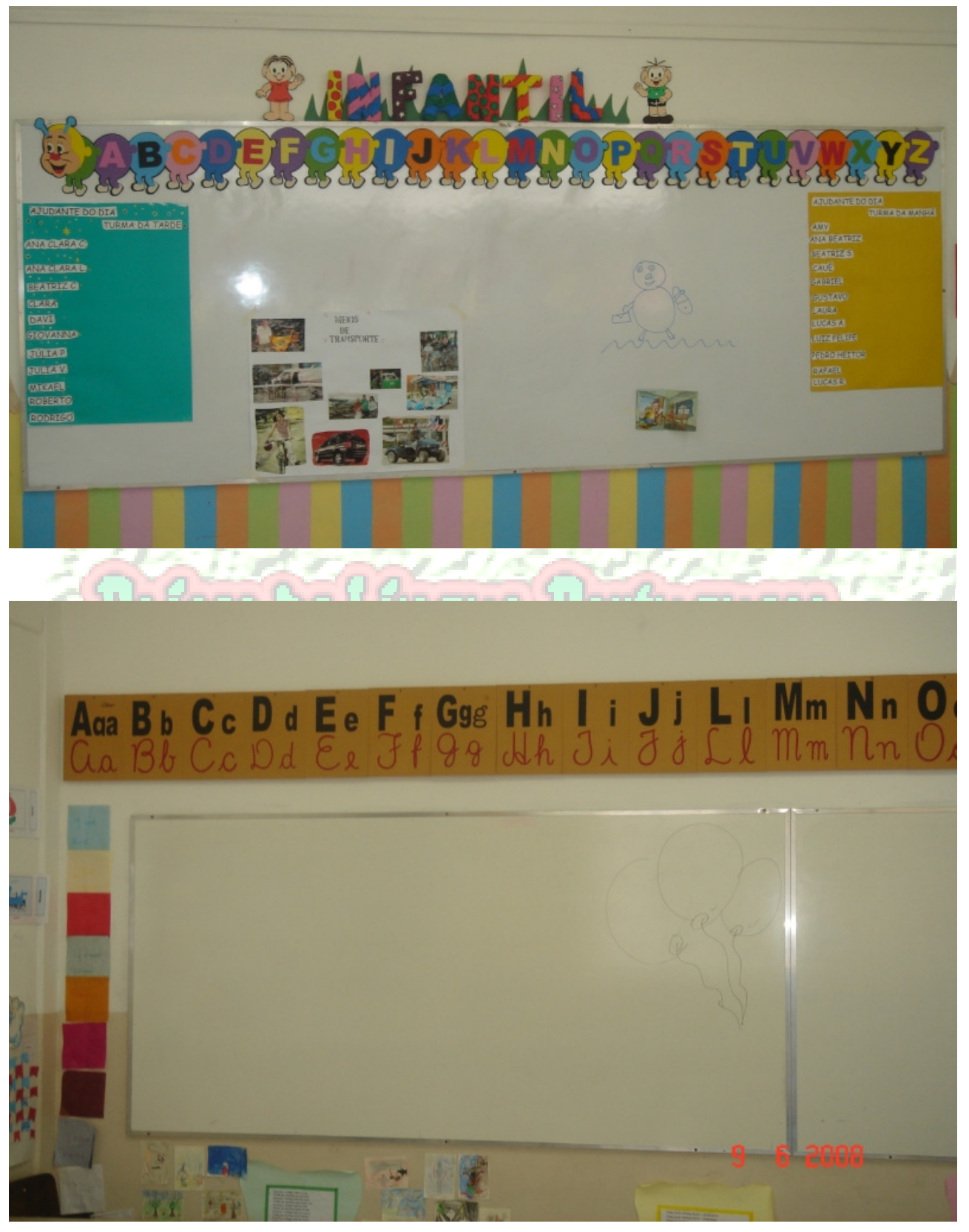

Foto da sala de primeiro ano (alfabetização) 


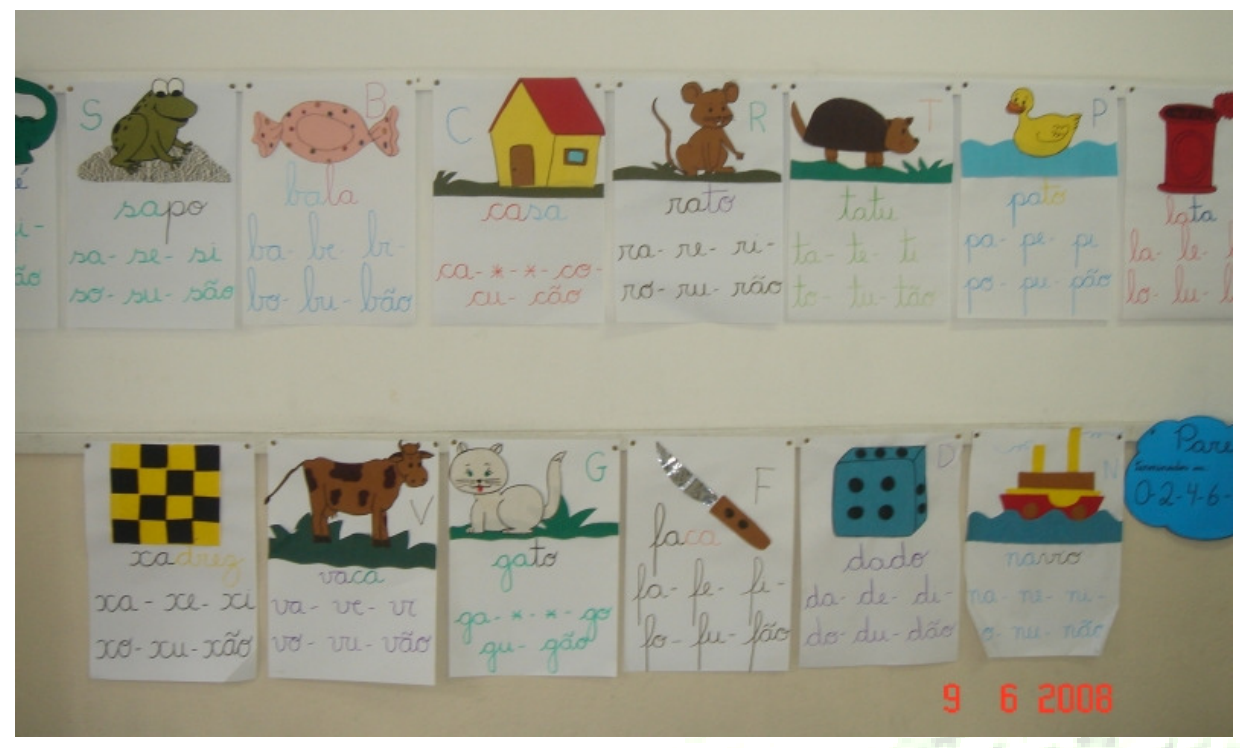

Foto da sala de primeiro ano (alfabetização)

\section{FOTOS- BLOCO 7}

Créditos: Letícia Arakaki

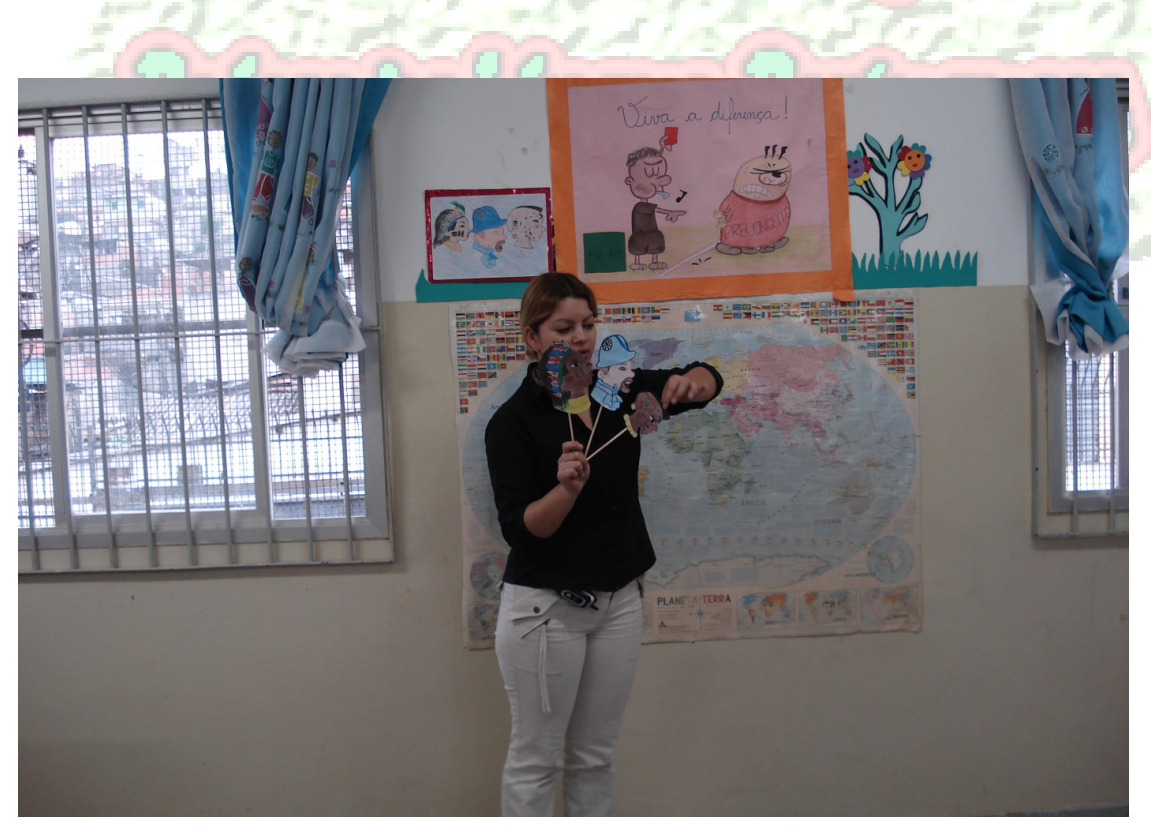




\section{Parte II: Relações raciais e sociais na cidade de São Paulo.}

\section{FOTOS- BLOCO 1}

Créditos: Carolline Ribeiro Lacerda, Manoela Ribeiro Paixão e Mirna Colazingari Barbosa

Fachadas e interior de escolas públicas em que apenas pessoas brancas são retratadas.

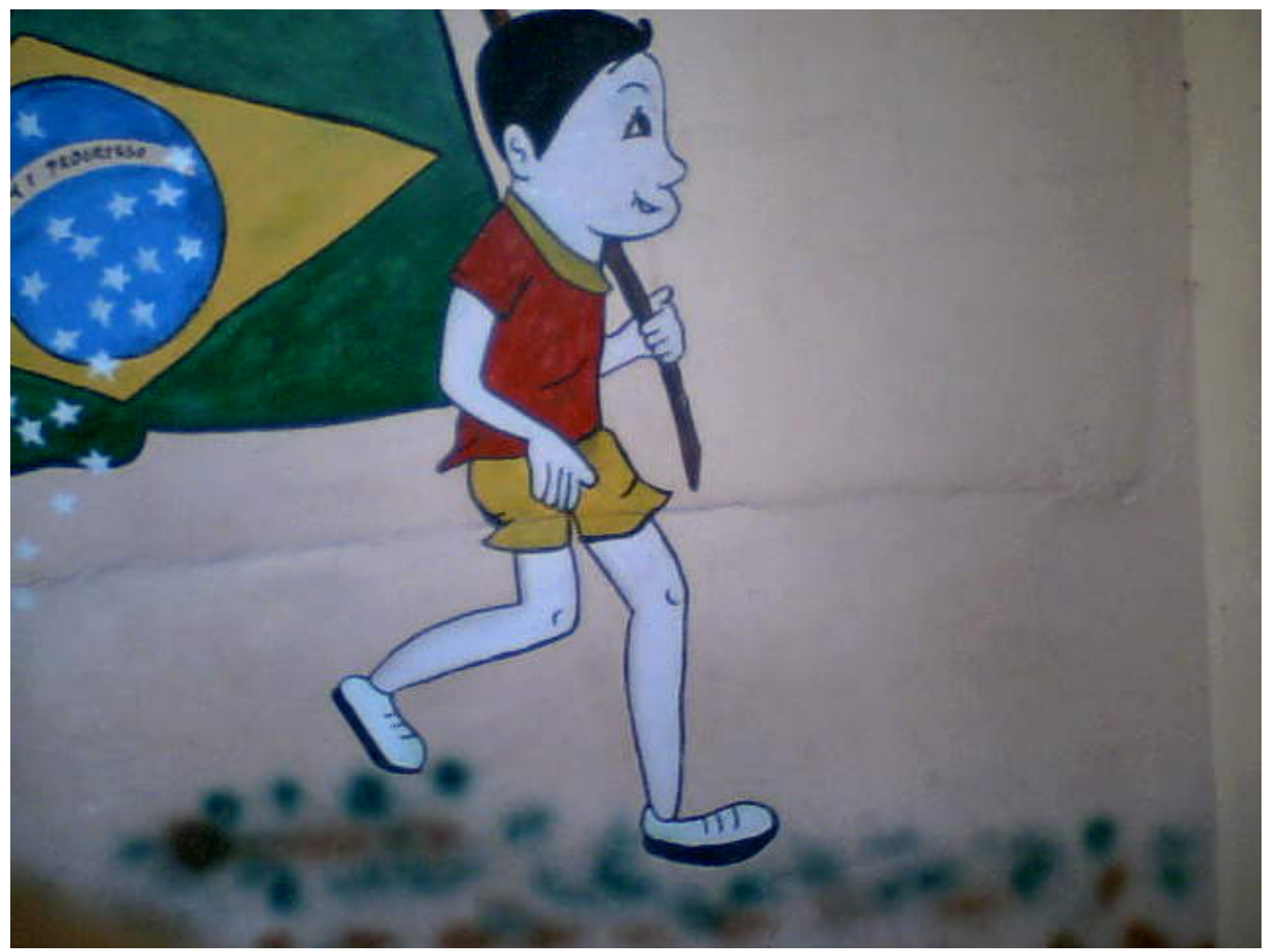



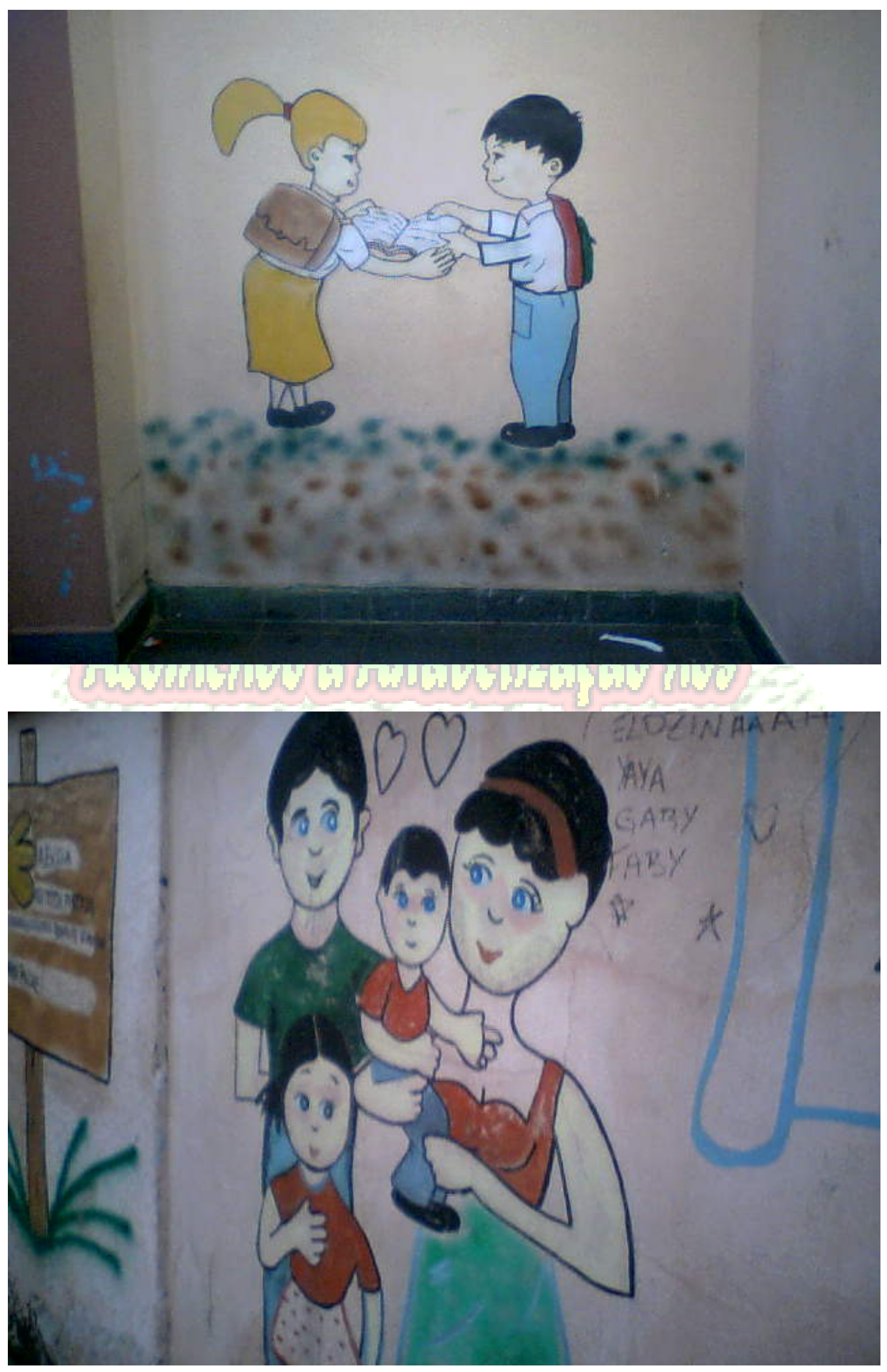


\section{FOTOS- BLOCO 2}

Relações familiares e sociais feitas por alunos do ensino fundamental

Créditos: Carolline Ribeiro Lacerda, Manoela Ribeiro Paixão e Mirna Colazingari Barboza

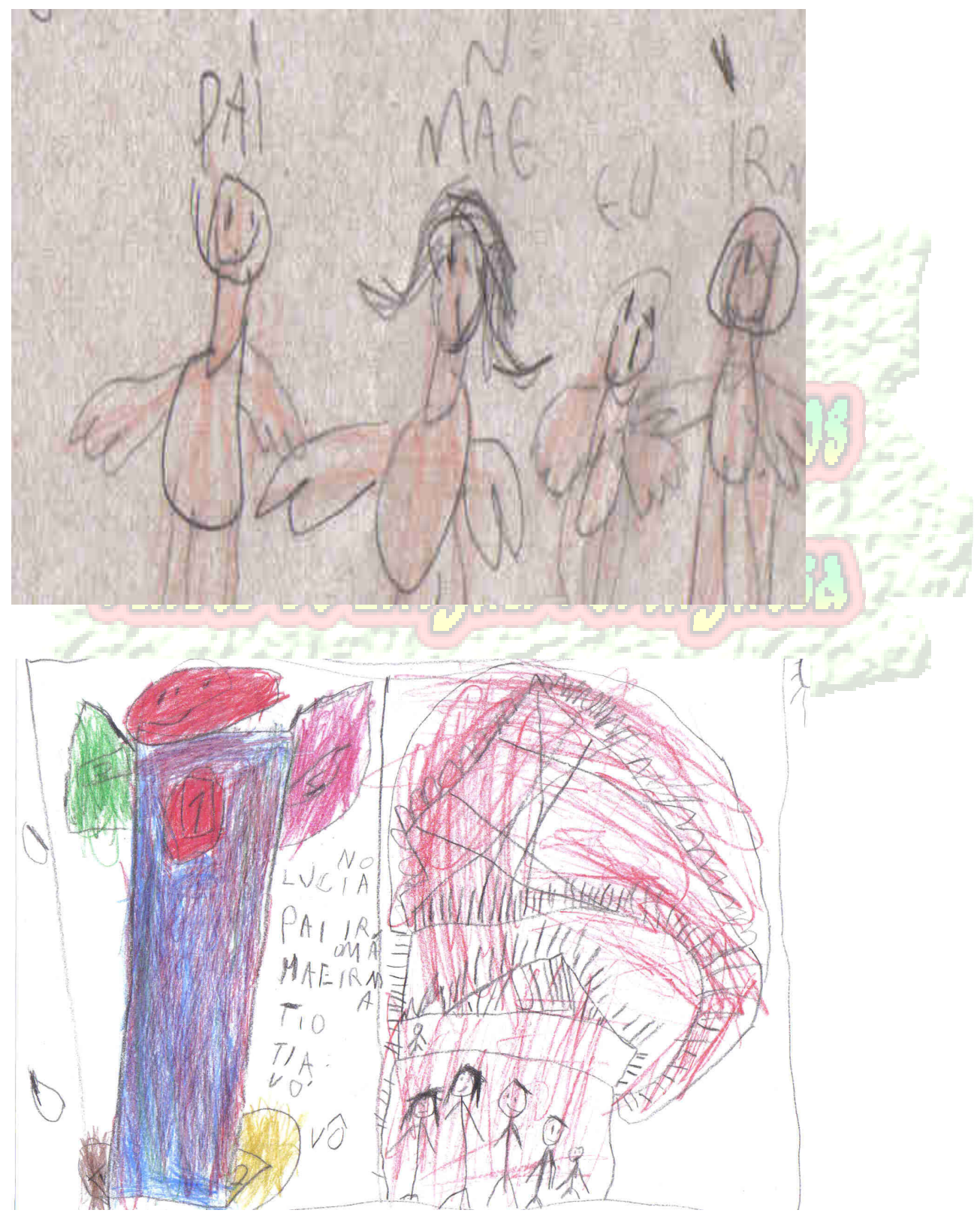



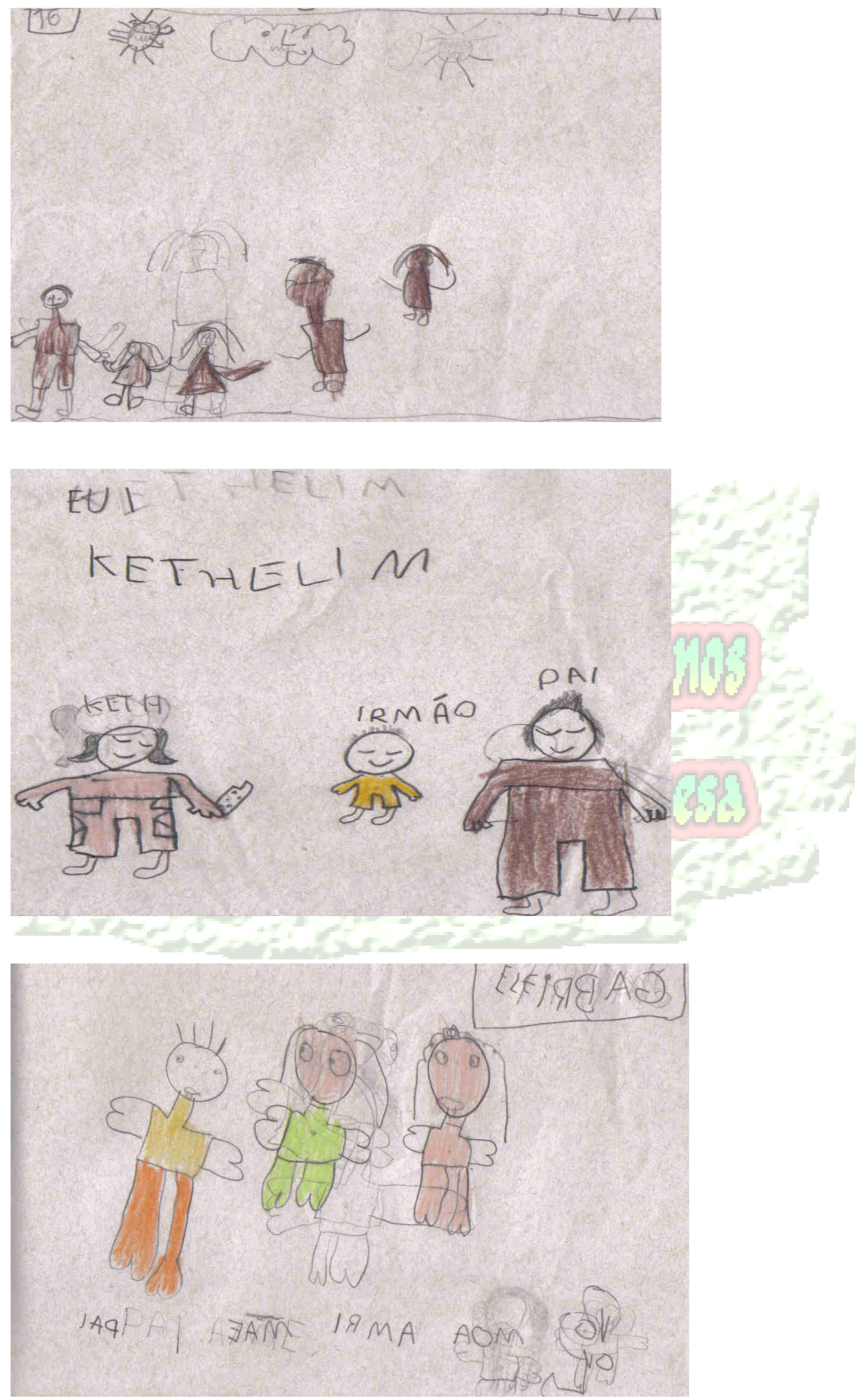


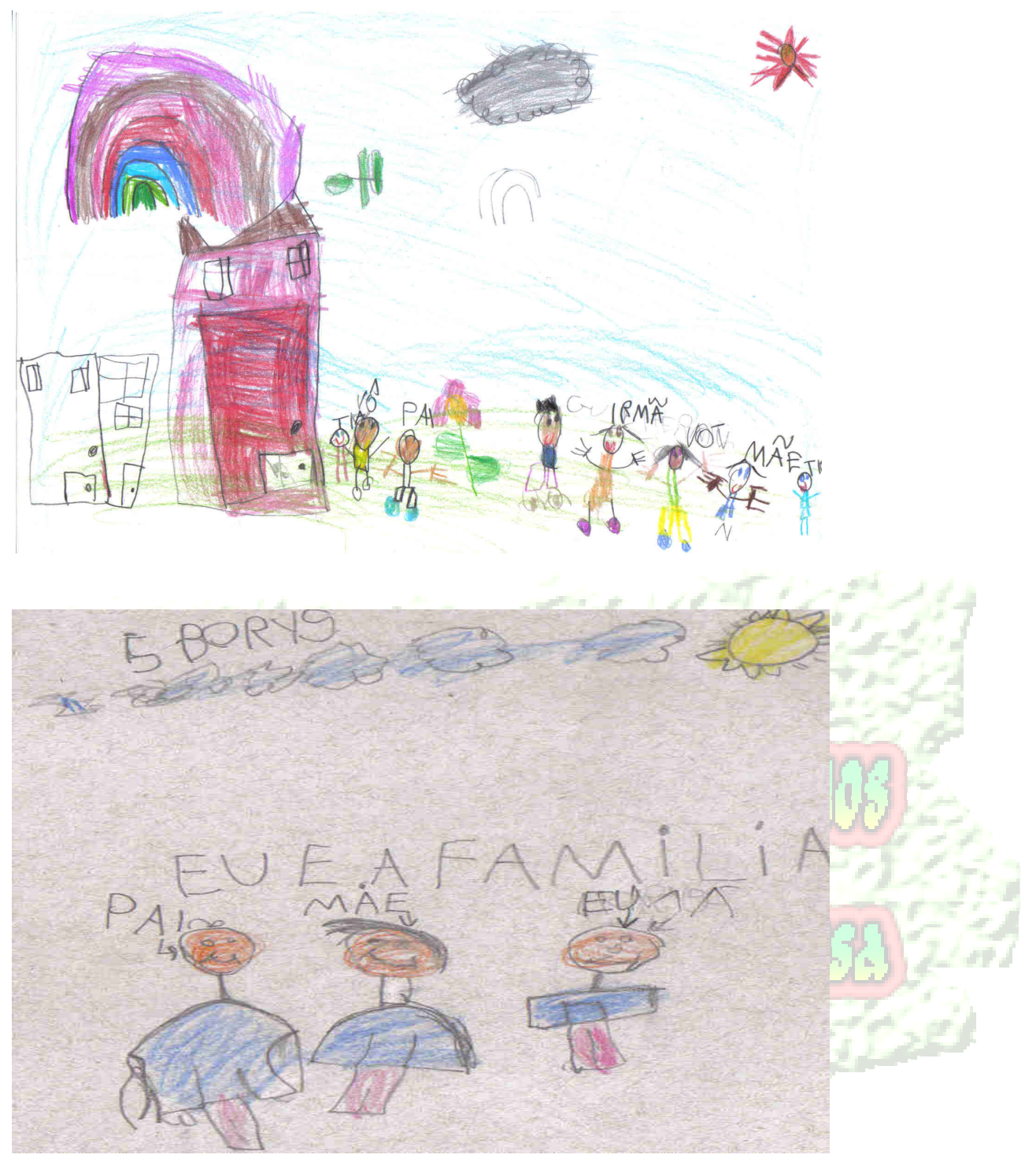

\section{FOTOS- BLOCO 3}

Créditos: Andréa Mesquita Rampone e Andréa Rigazzo Maiolino

Bonecas de uma escola de classe média alta 


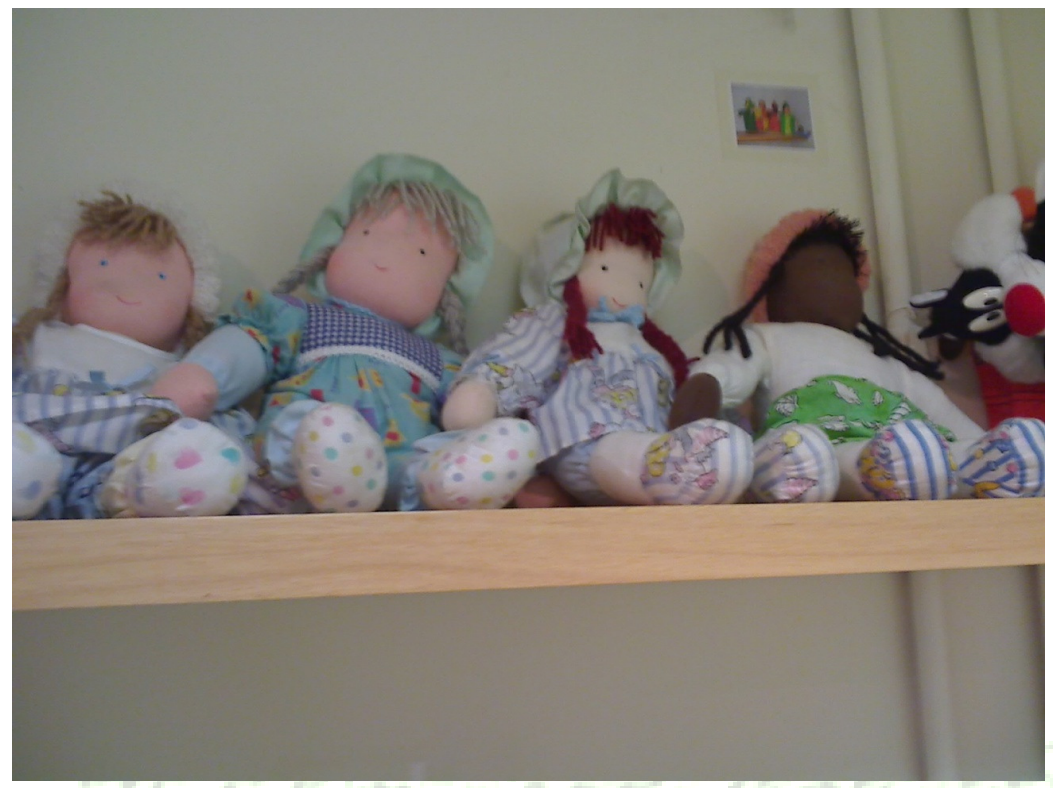

\section{FOTOS- BLOCO 4}

Créditos: Fernanda Morales

Vitrine de uma loja de Shopping de luxo na cidade de São Paulo

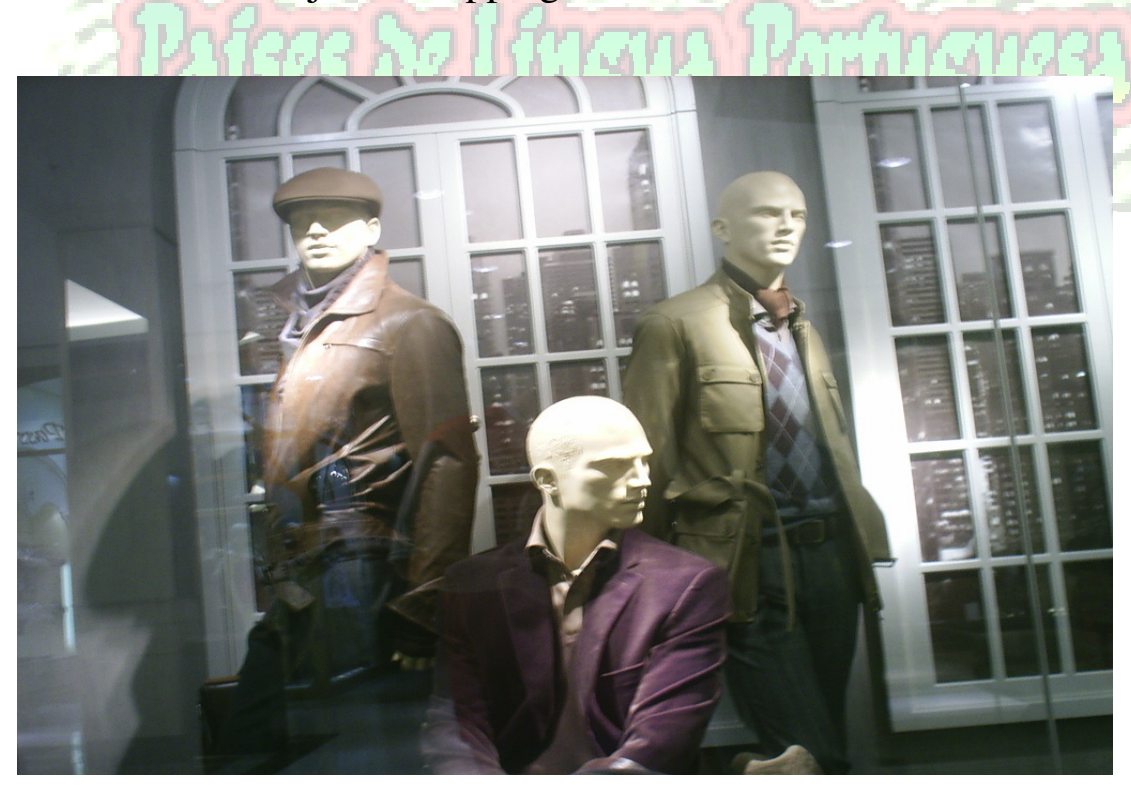




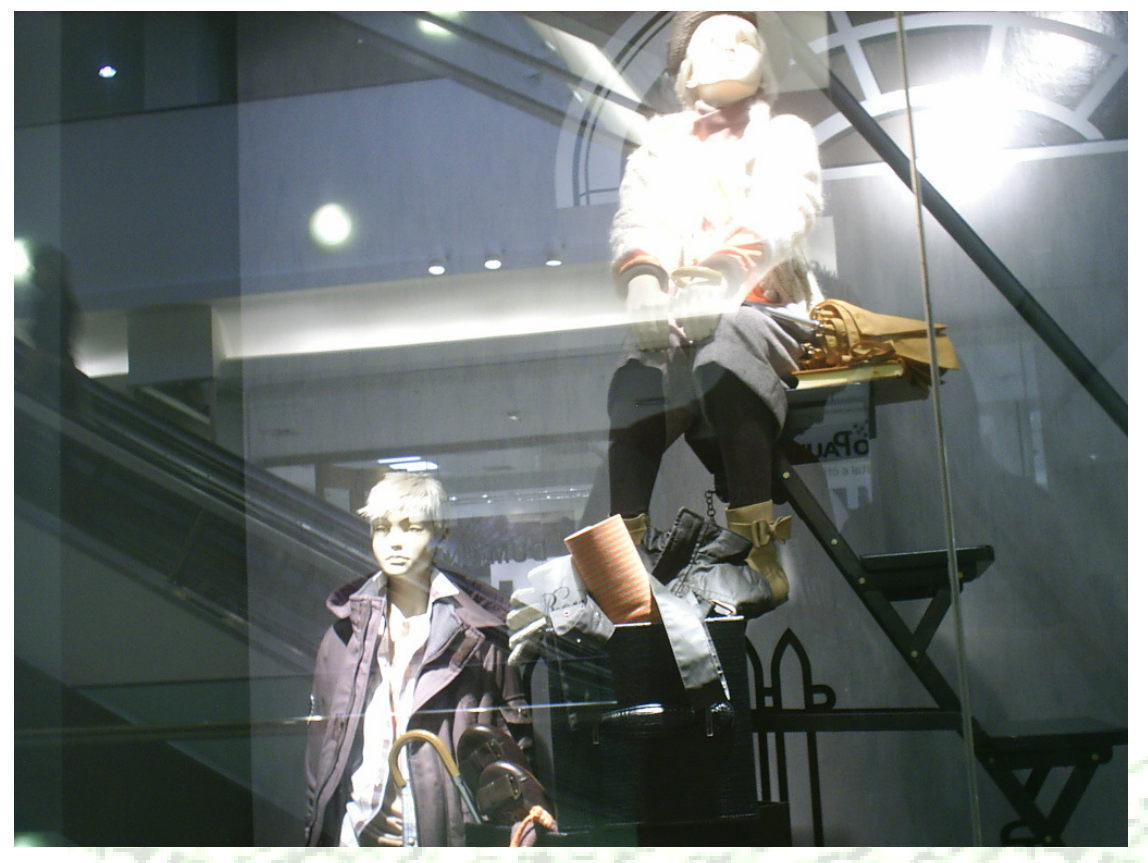

Vitrines de lojas de brinquedo em Shopping de luxo na cidade de São Paulo

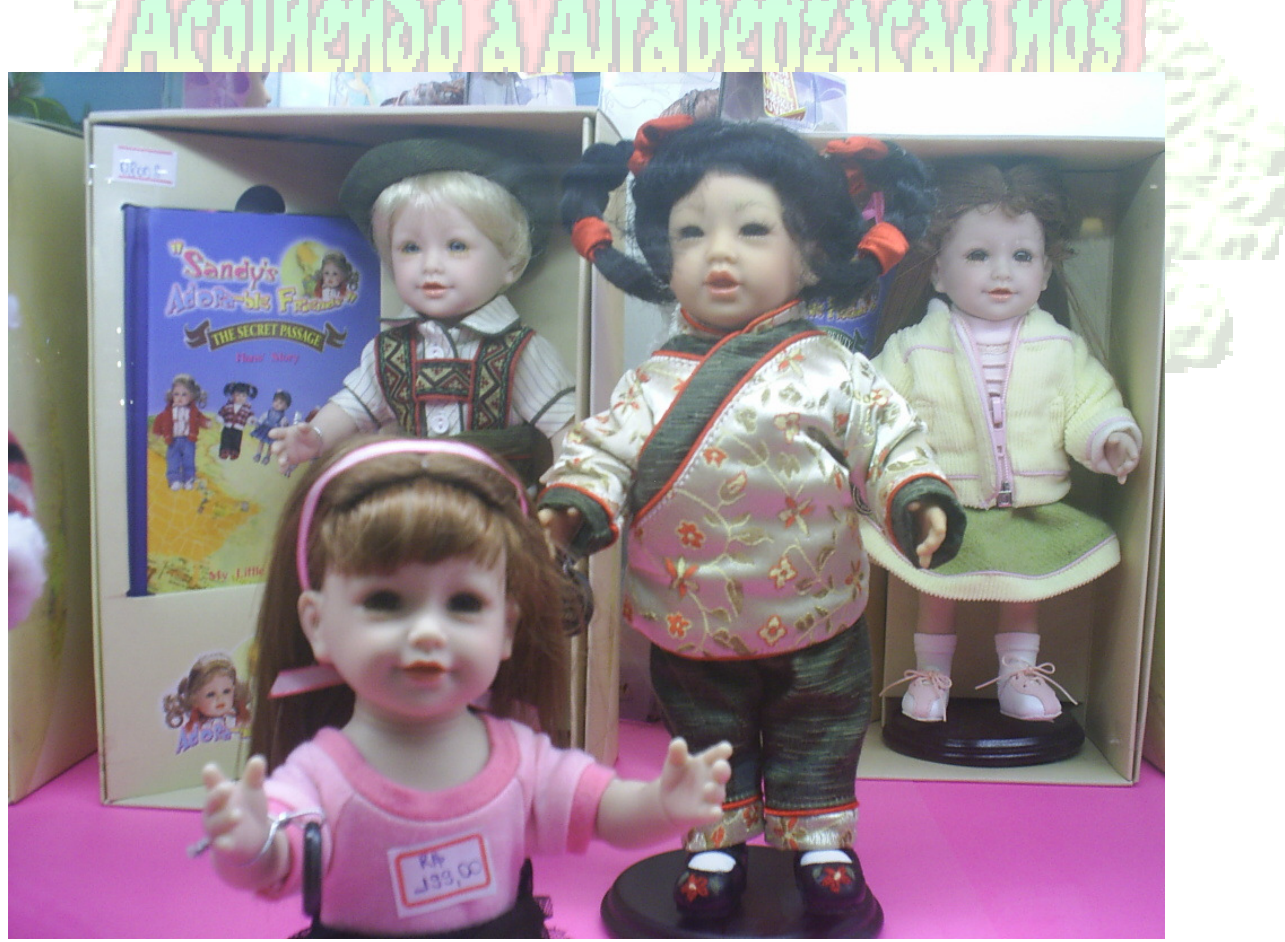



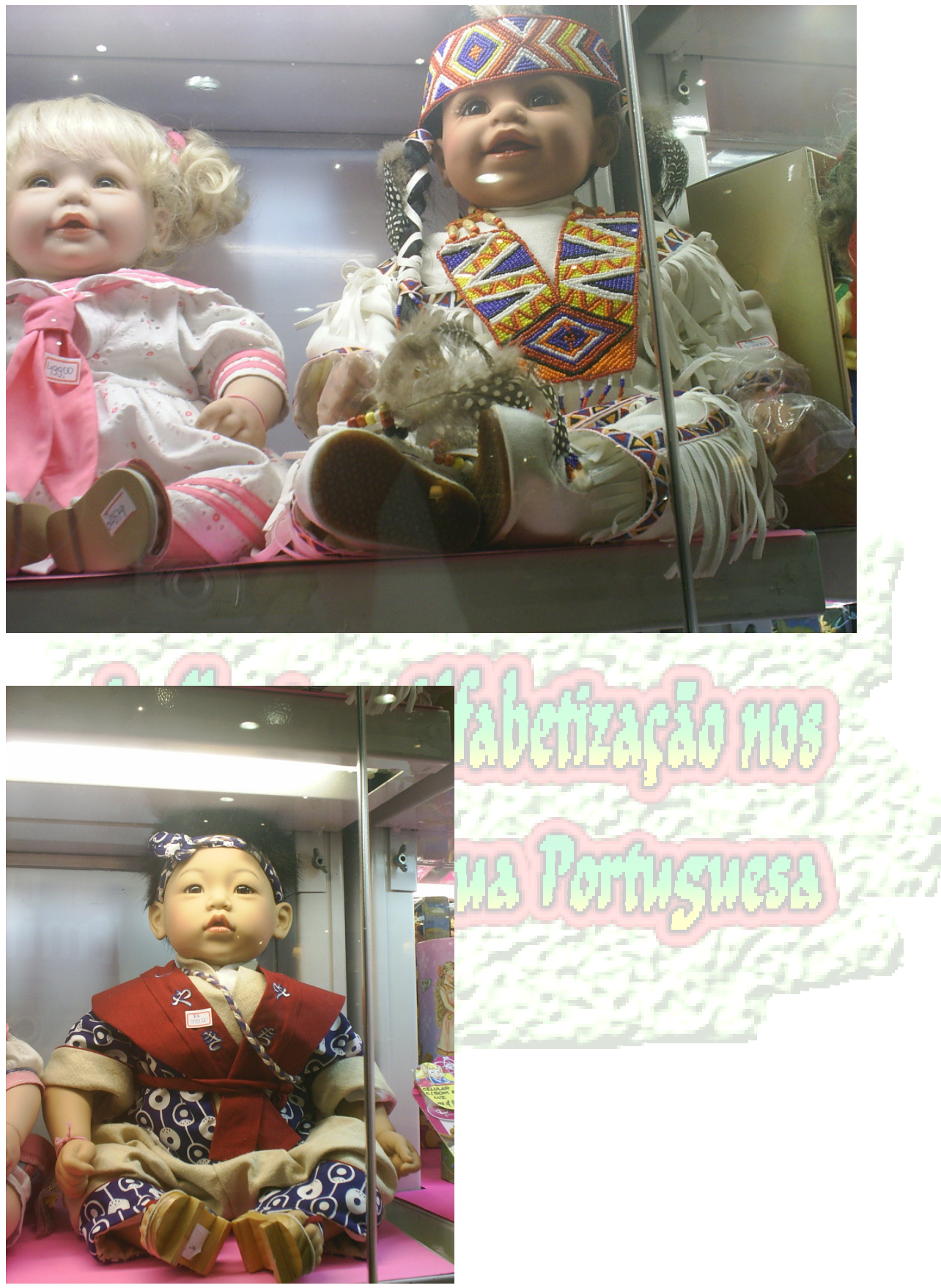


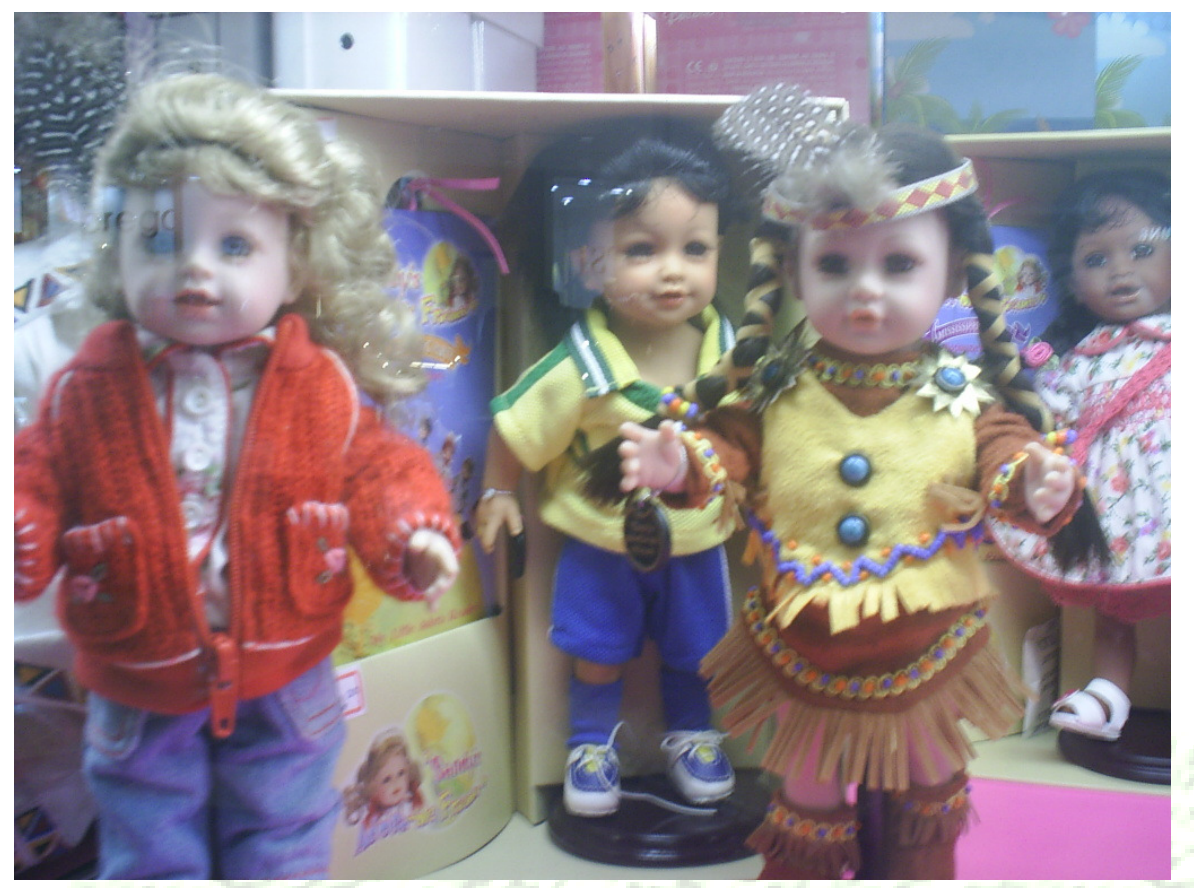

Bonecas Barbie negras - as únicas que havia eram essas... de biquíni, moradoras da praia! Nenhuma médica, aeromoça ou professora!

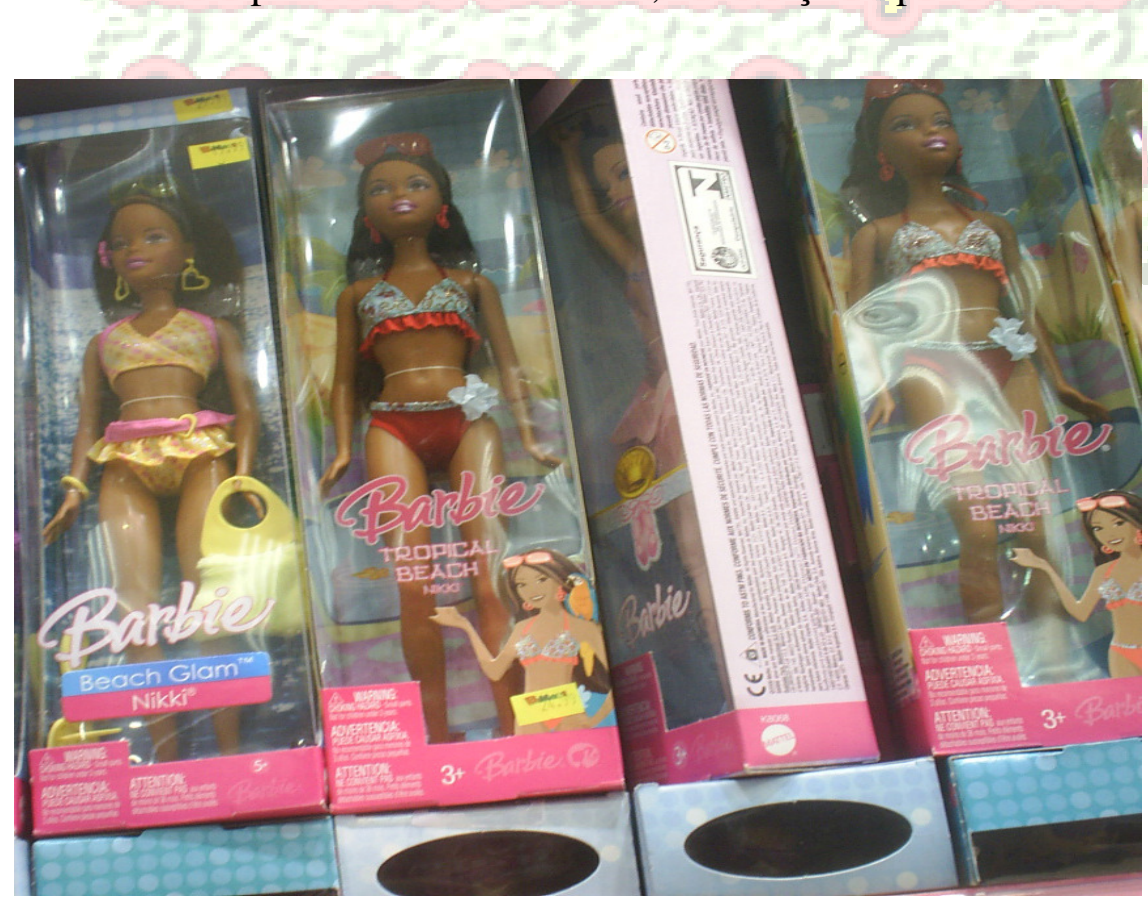


Foto de uma casa em condomínio fechado em SP (Parque dos Príncipes).

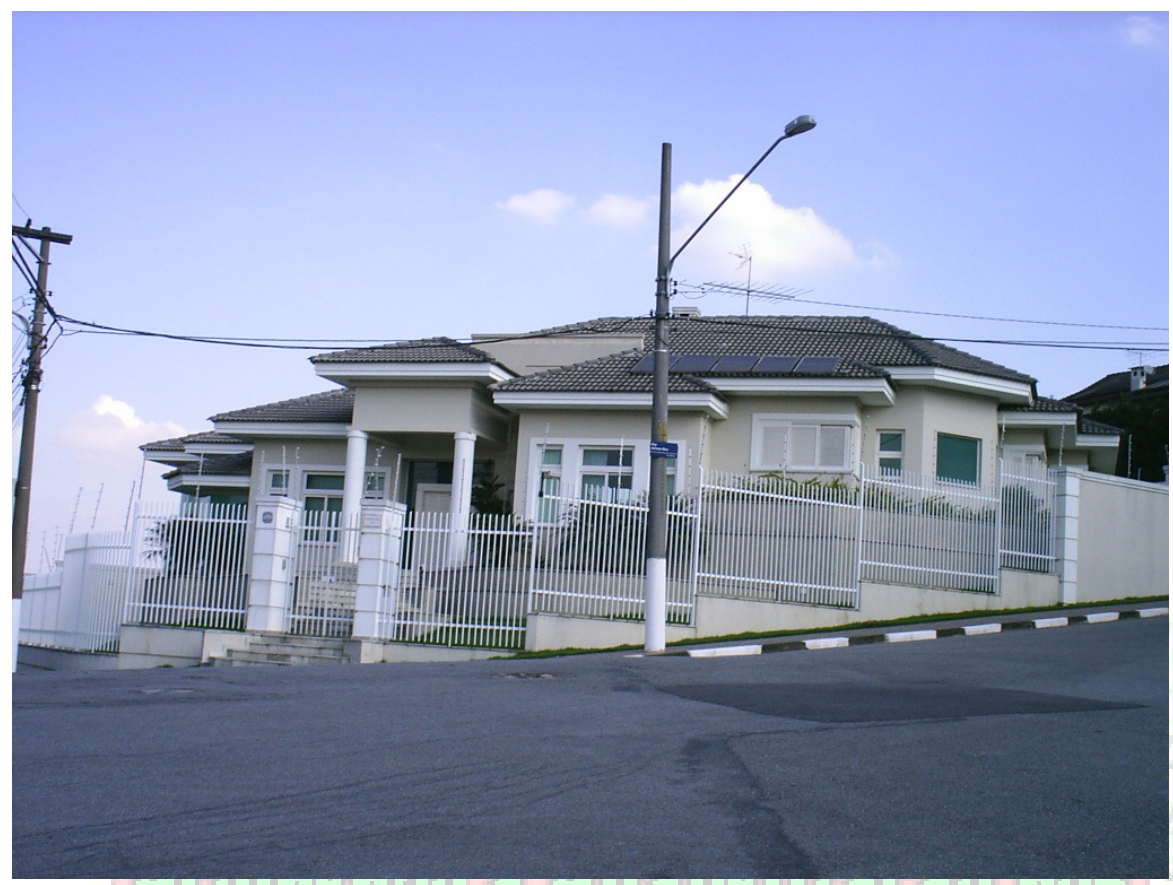

E outra casa de luxo do mesmo condomínio. Quem serão os moradores dessas casas enormes? Provavelmente, ricos brancos e doutores!

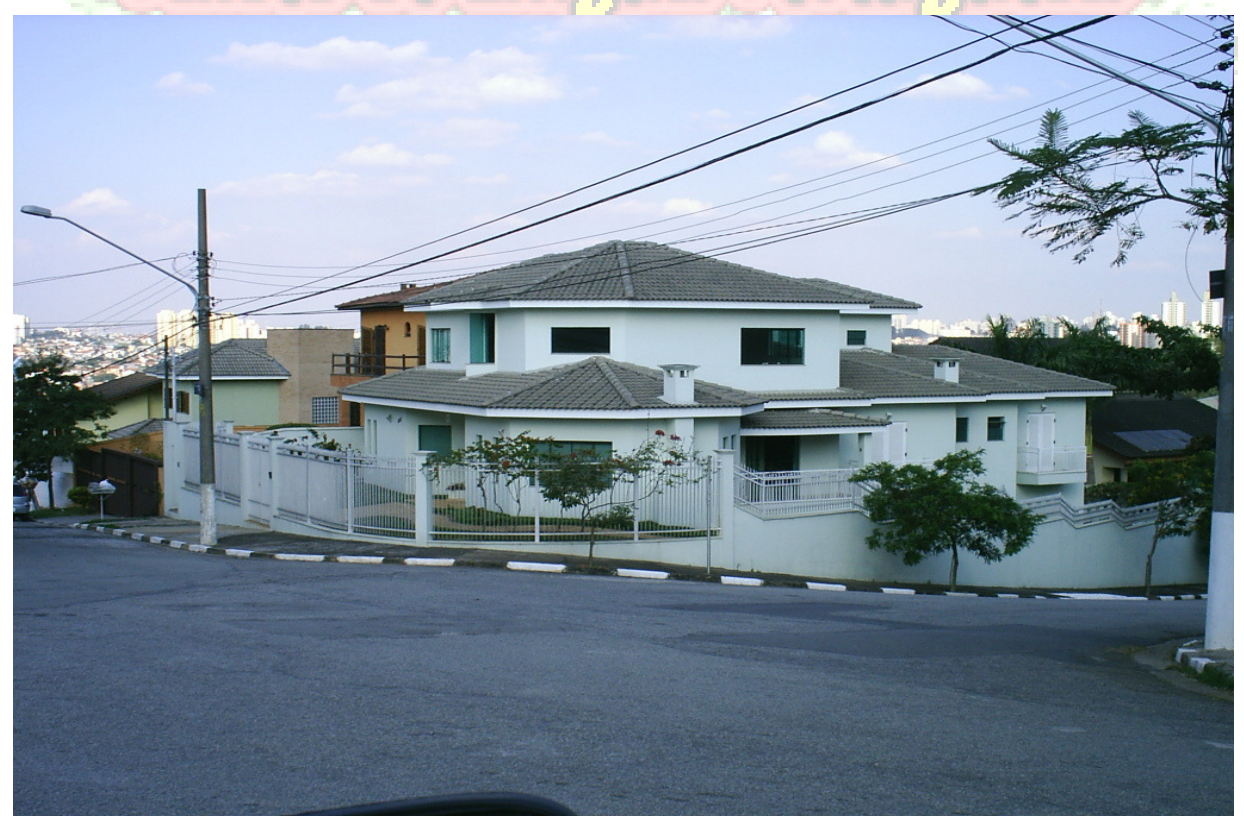


Colégio Albert Sabin dentro do Parque dos Príncipes - as "facilidades" para os filhos dos ricos.

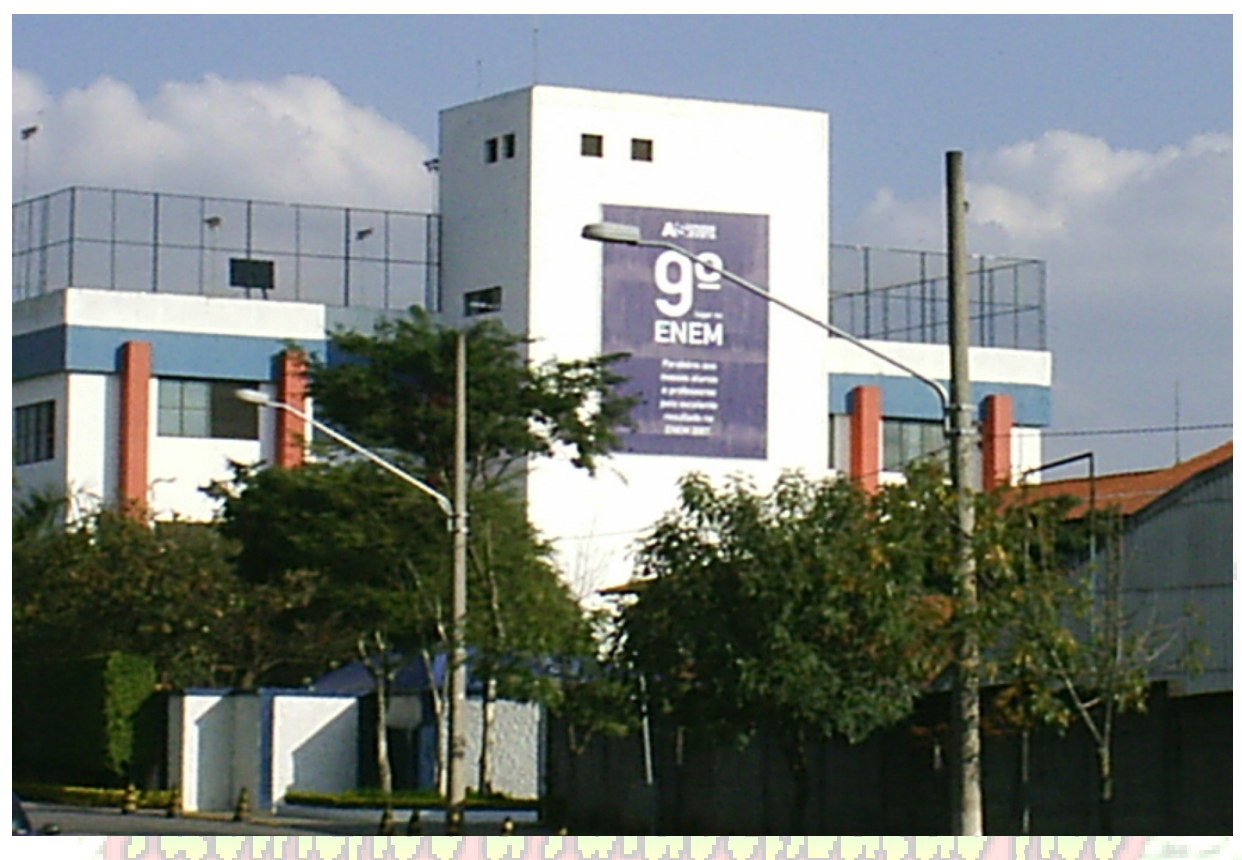

E a escola de Inglês CNA - mais um dos "luxos" dos moradores desse condomínio.

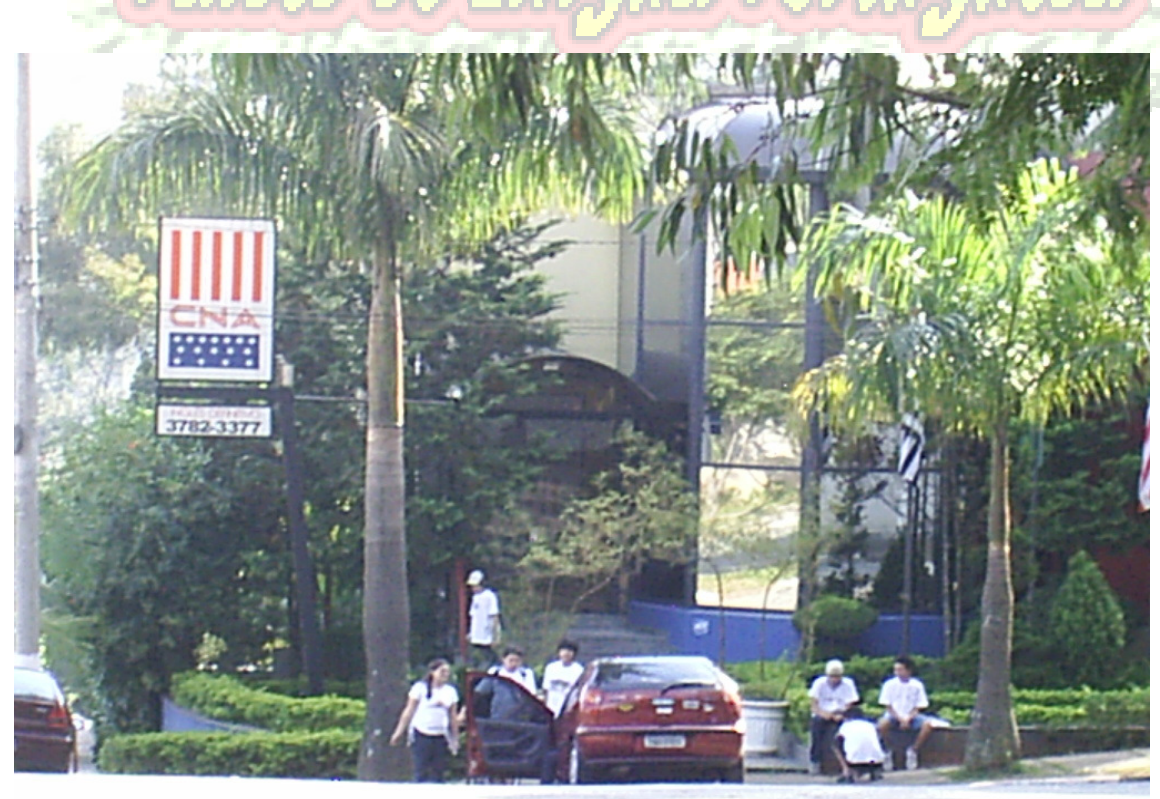


Mas como o Brasil é um país de imensos contrastes sociais... esta favela fica bem atrás do condomínio Parque dos Príncipes.

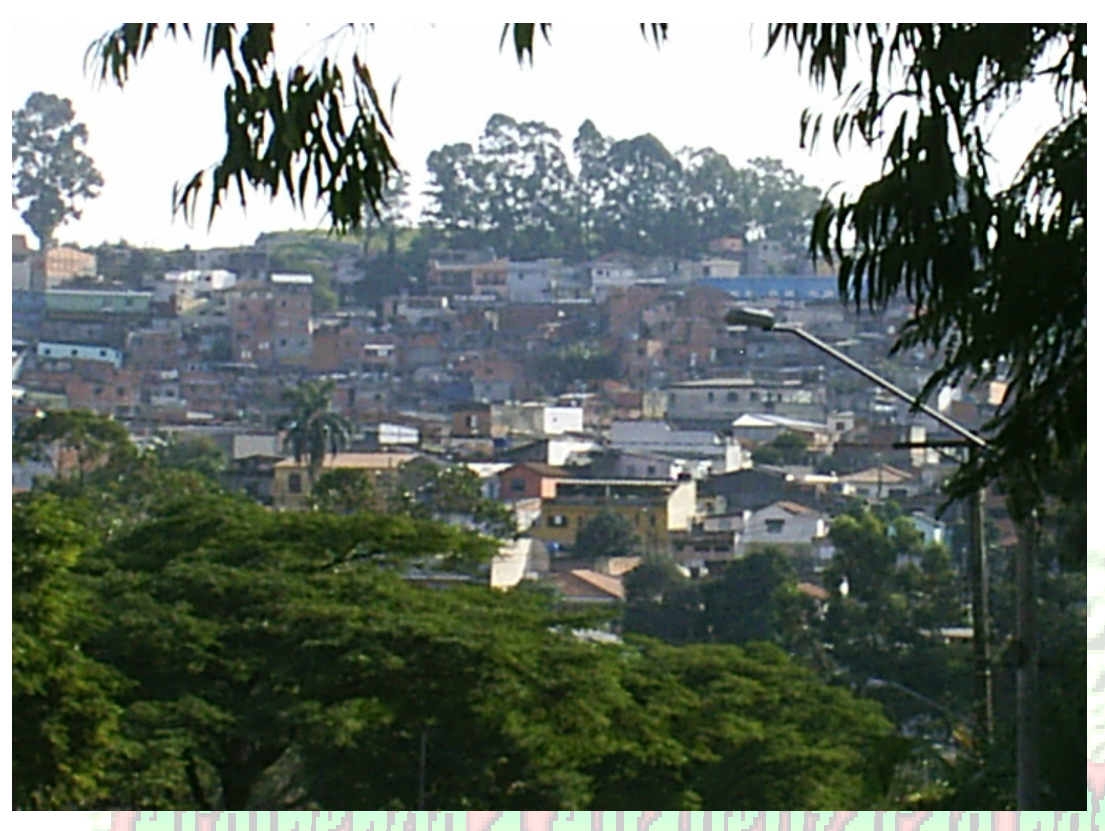

Entrada para a favela - mureta dividindo fisicamente esses dois "mundos" tão diferentes!

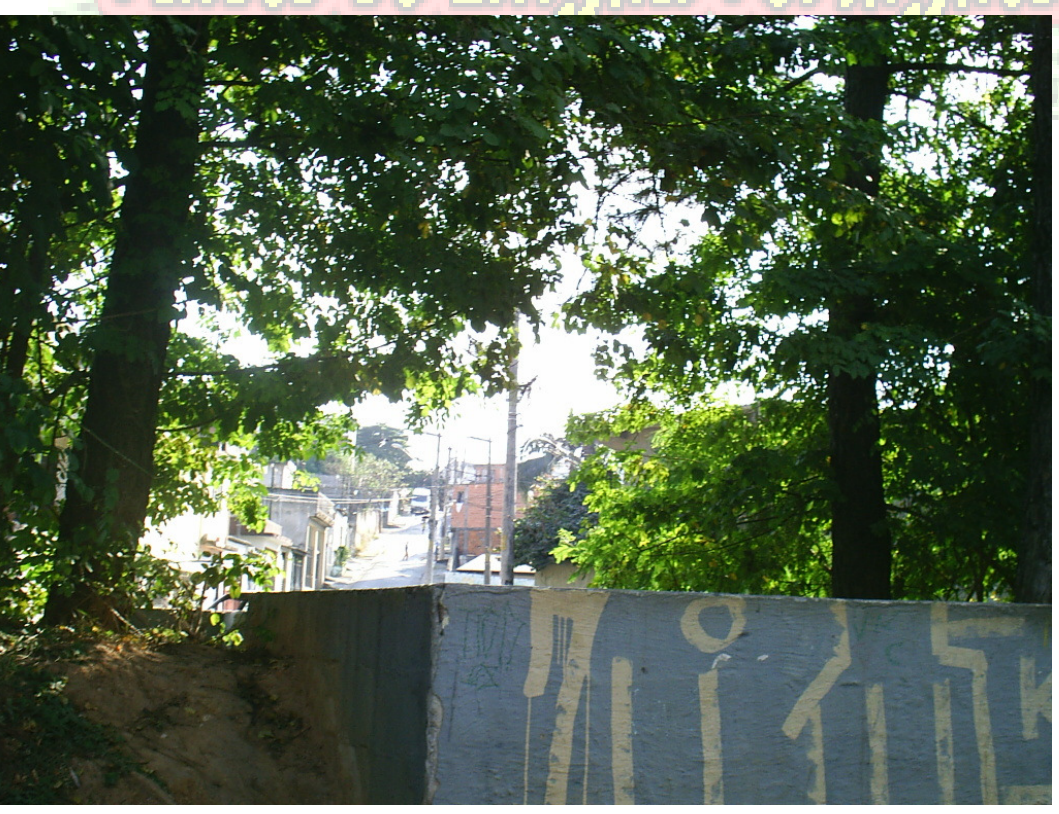




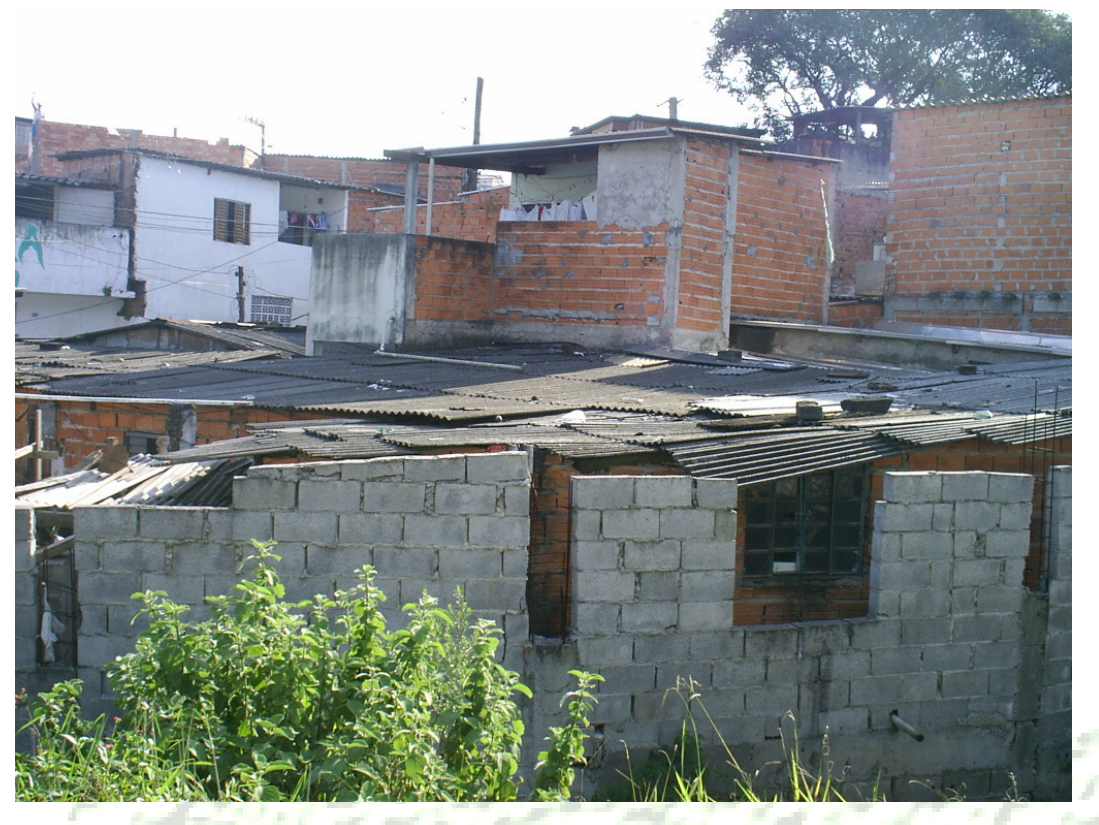

Outra foto da favela... que enorme diferença casas que estão separadas apenas por alguns metros!

E os moradores dessas casas, quem serão? Os pobres, negros. É claro!

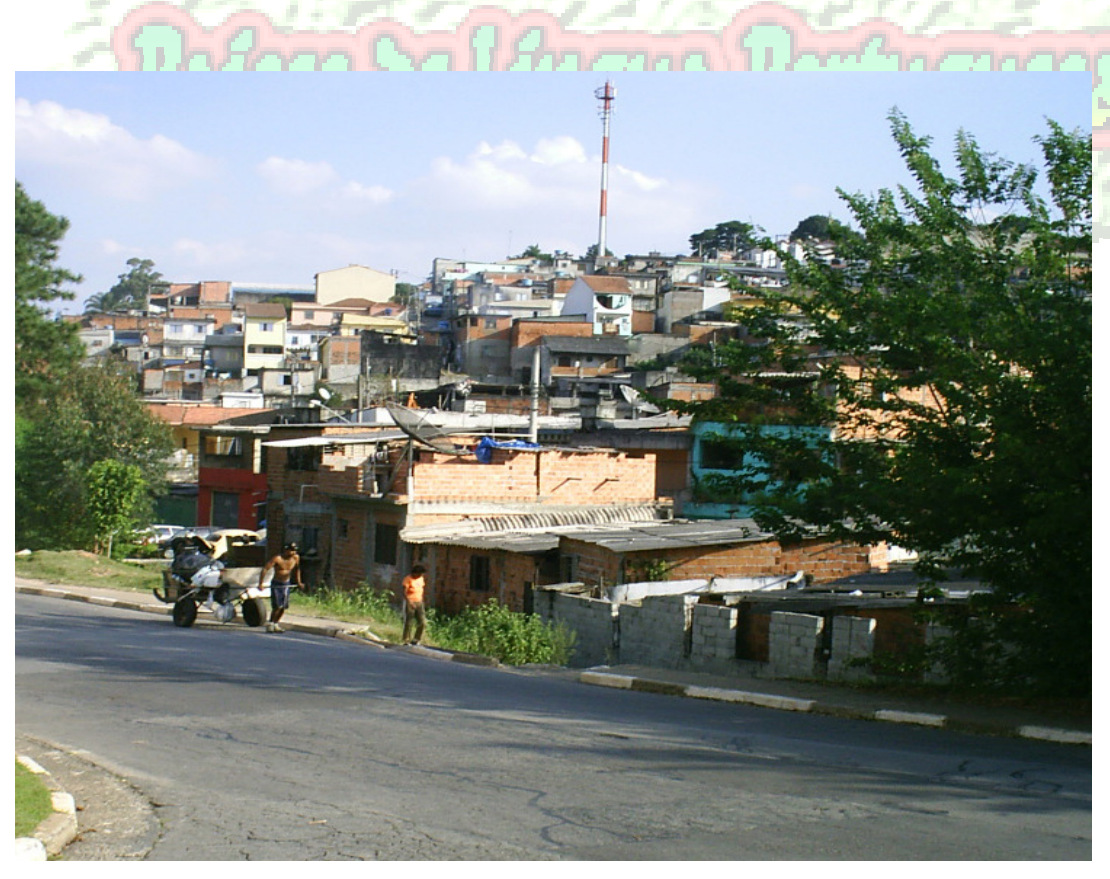


E esta é a quadra de uma EMEF bem ao lado da favela, há poucos metros de distância do Sabin.

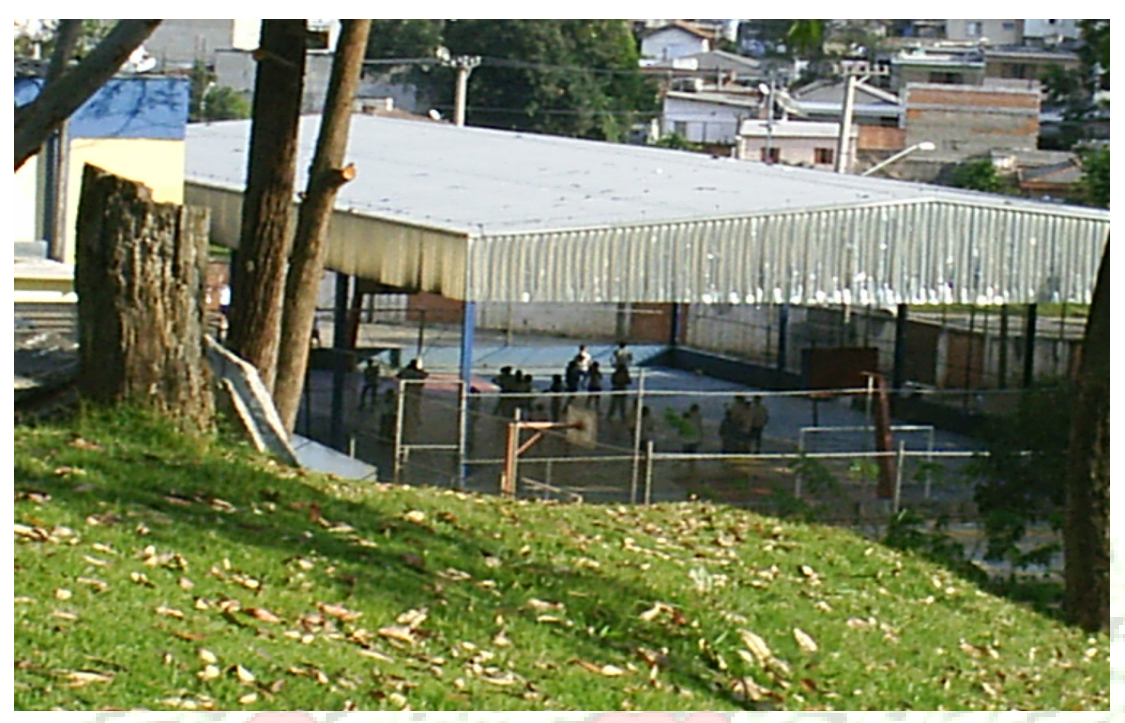

E para finalizar - Foto de uma favela bem próxima da Universidade de São Paulo, a maior e melhor da América Latina, do Hospital Universitário, para nos lembrar sempre que no Brasil mundos tão diferentes convivem lado a lado.

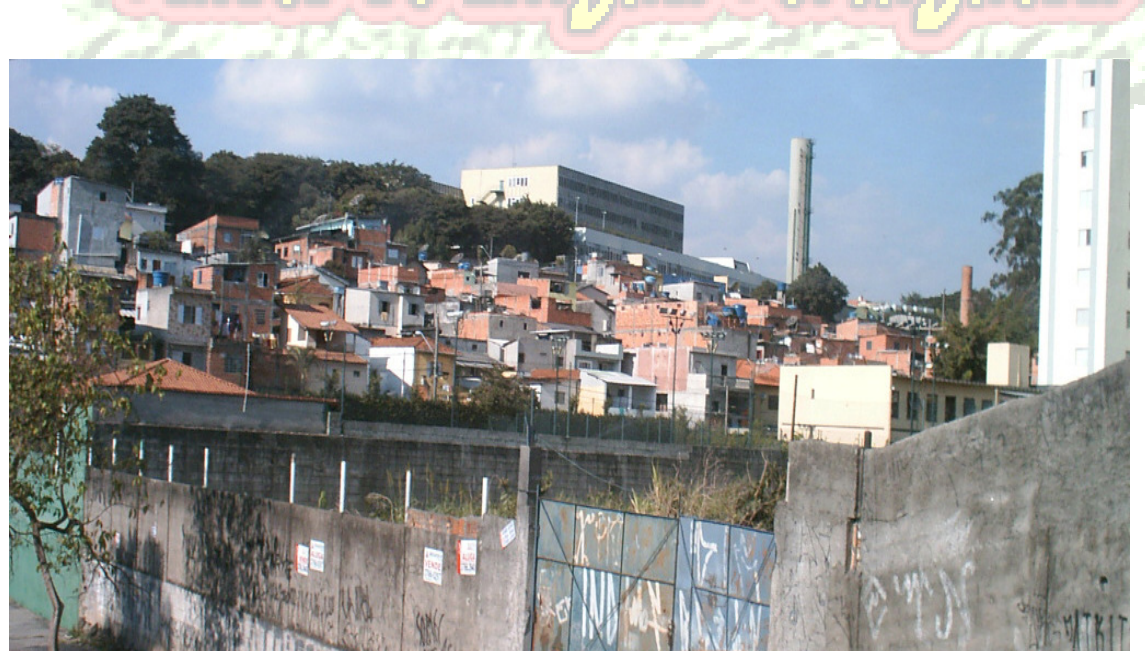




\section{FOTOS: BLOCO 5}

Créditos: Jacqueline Simões, Paulo Genovese, Vânia Daré e Viviane

\section{Castro}
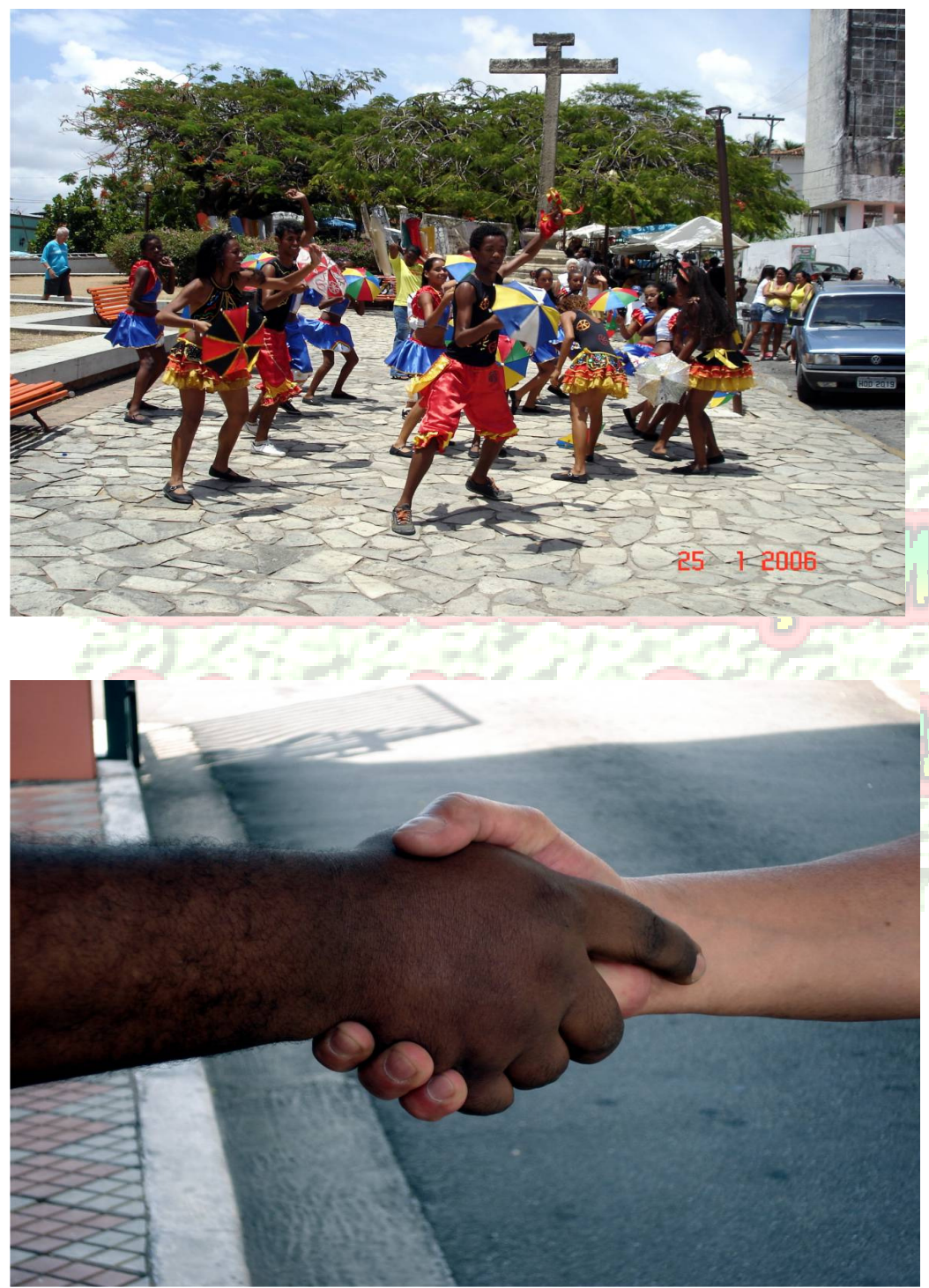


\section{FOTOS- BLOCO 6}

Créditos: Adriana Santos Rodrigues da Silva, Ana Beatriz de Medeiros Pereira, Aryadne de Moraes Fernandes da Silva, Maria Cláudia Ligori Figueiredo e Thaís Ginícolo Cabral

Inicialmente, podemos notar fotos que mostram a desigualdade social e miséria em que vive parte da população.
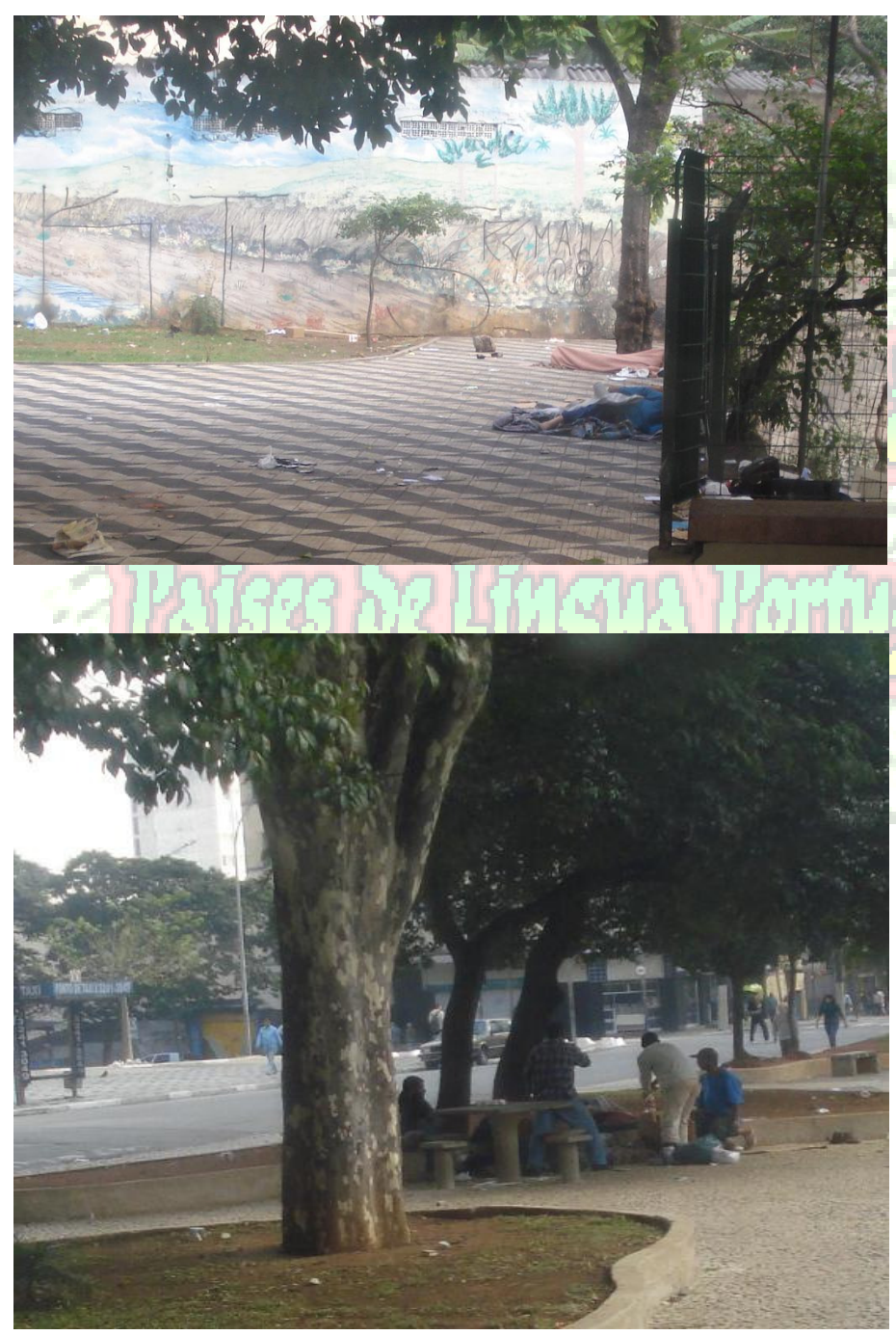

Fotos tiradas moradores de rua, em praças no centro de São Paulo. 


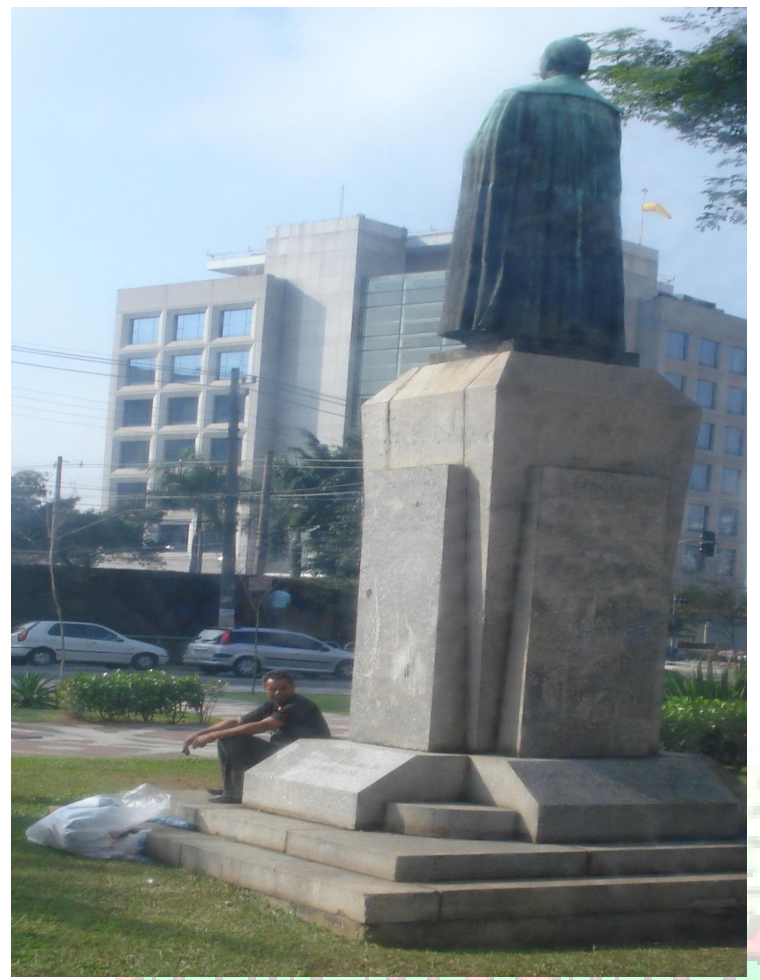

Foto tirada de praça em São Paulo, demonstrando o contraste entre classes sociais presente em nossa sociedade.
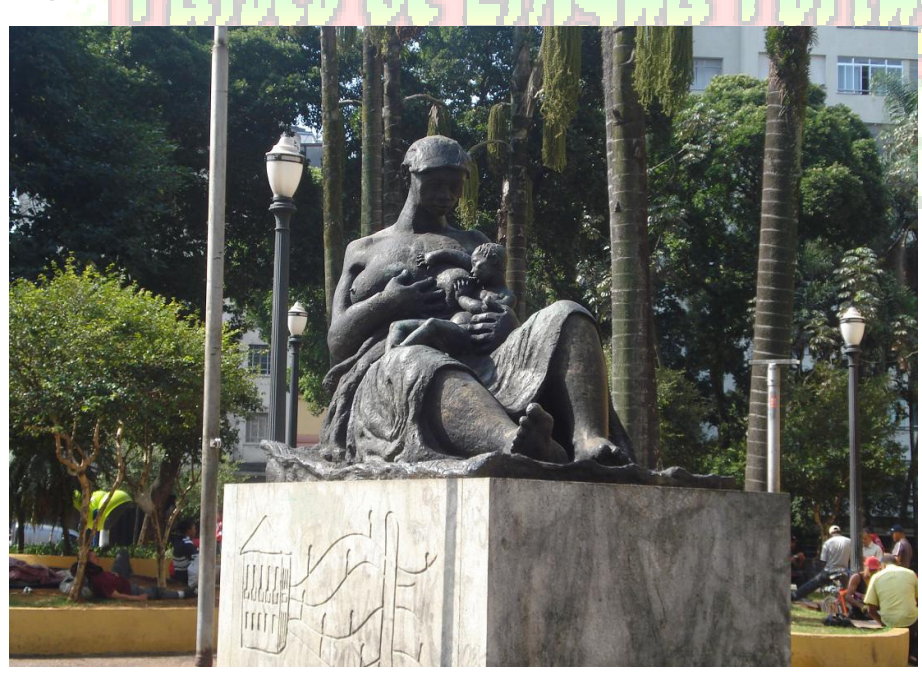

Foto tirada da Praça Paissandu, no centro de São Paulo, o monumento denominado "Mãe Preta" mostra a raiz africana em nossa sociedade. 


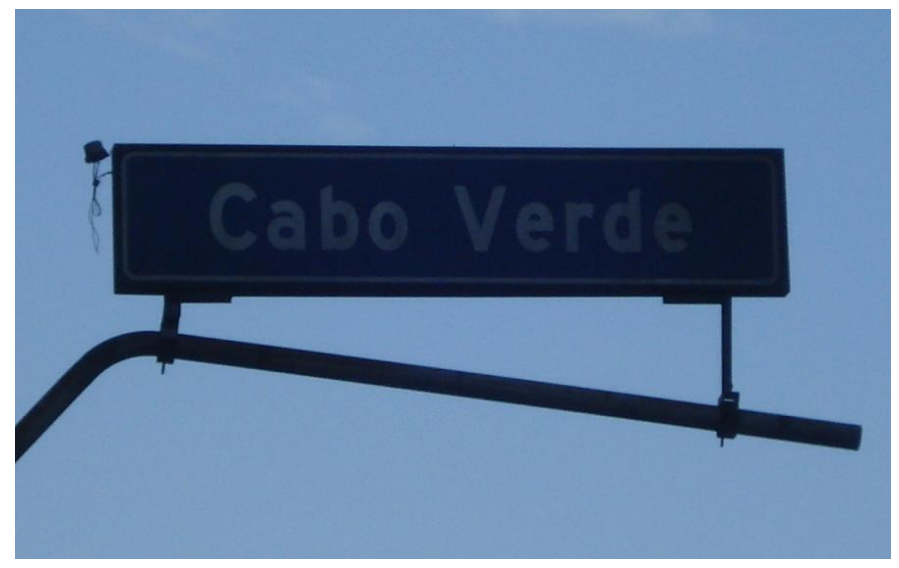

Foto tirada de placa de rua em São Paulo, raízes africanas.

A seguir, uma sequência de fotos com nome de Bairros, Ruas e Avenidas da Cidade de São Paulo, com origem indígena.


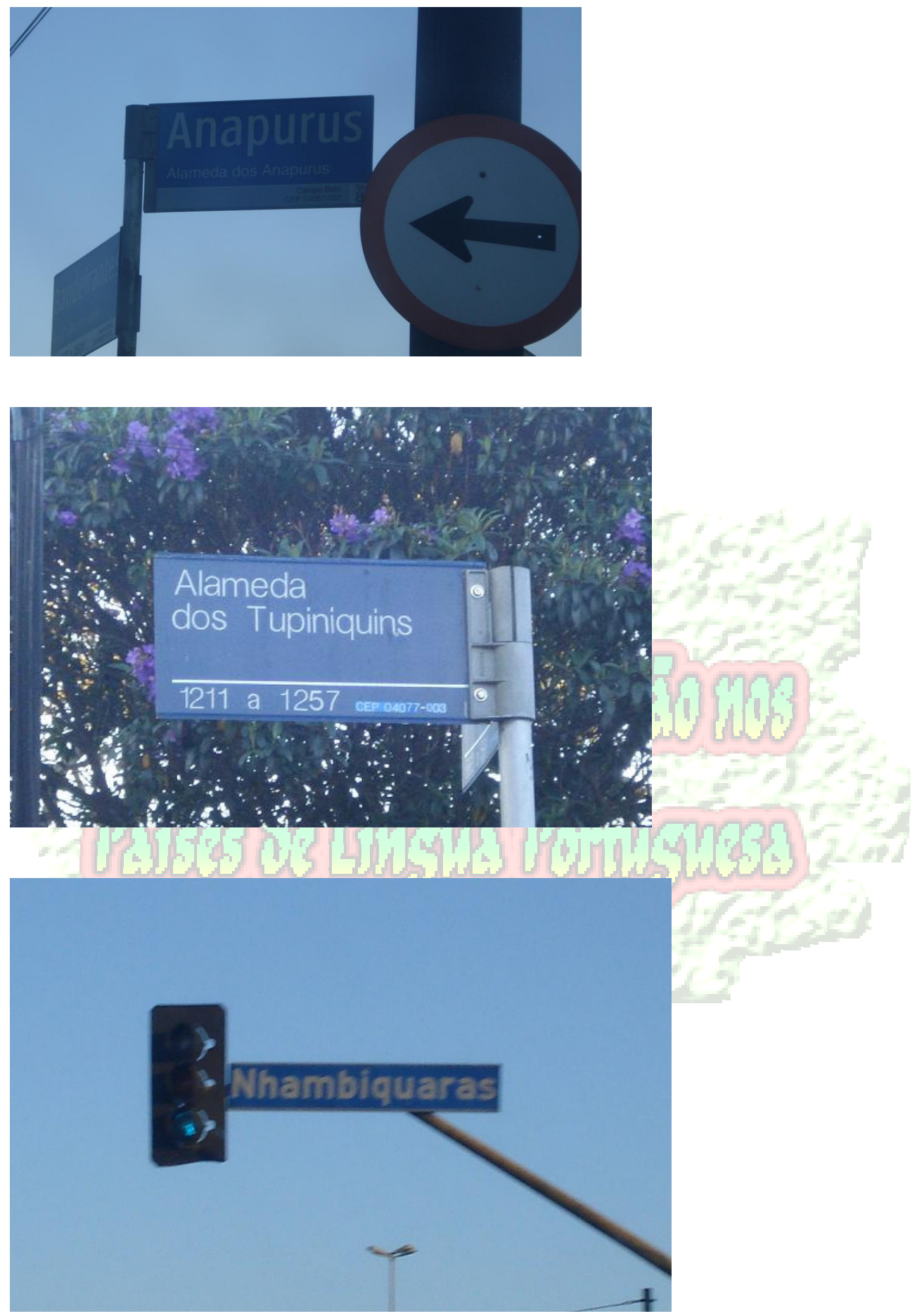

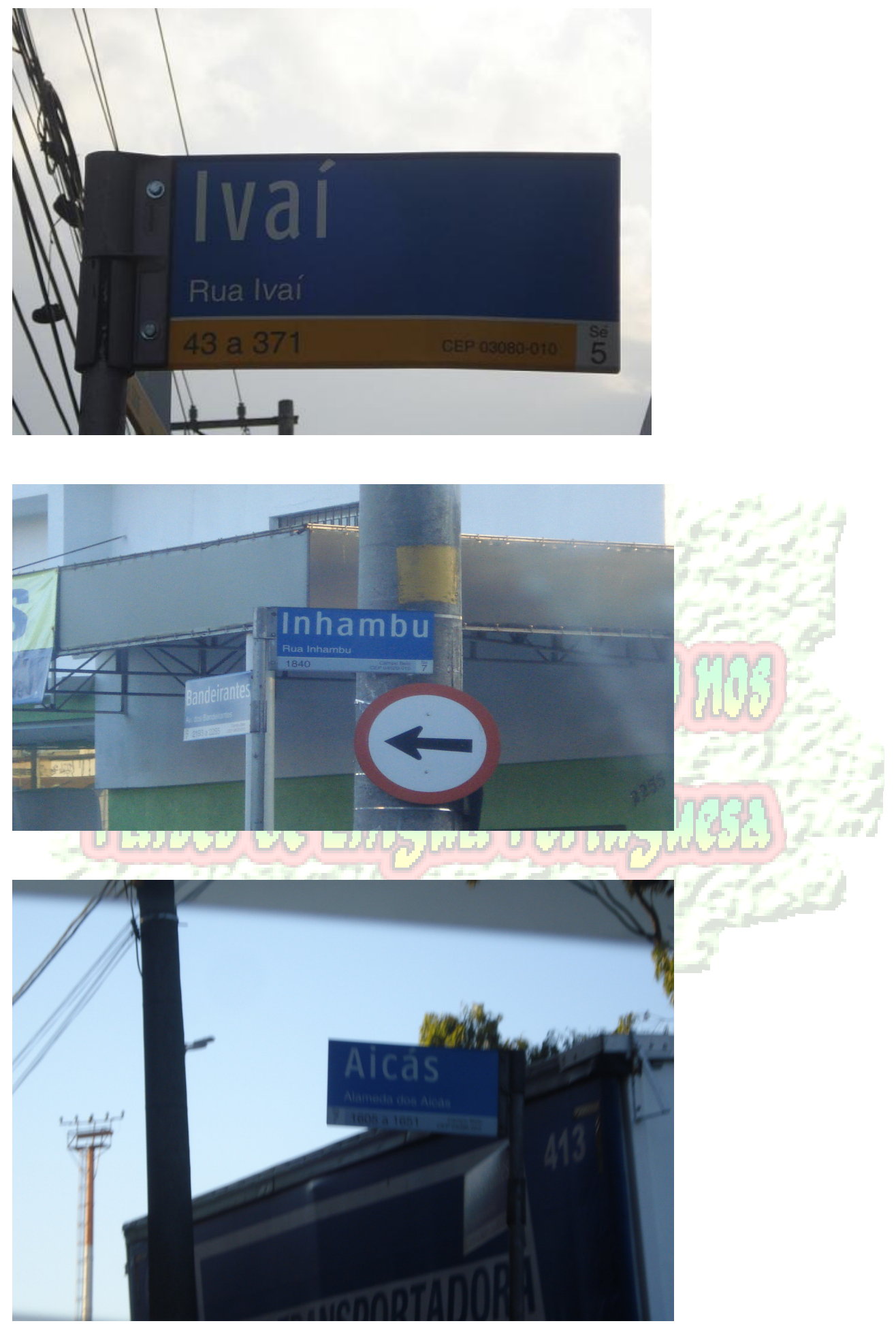


\section{FOTOS- BLOCO 7}

Créditos: Débora Thais Sales dos Santos
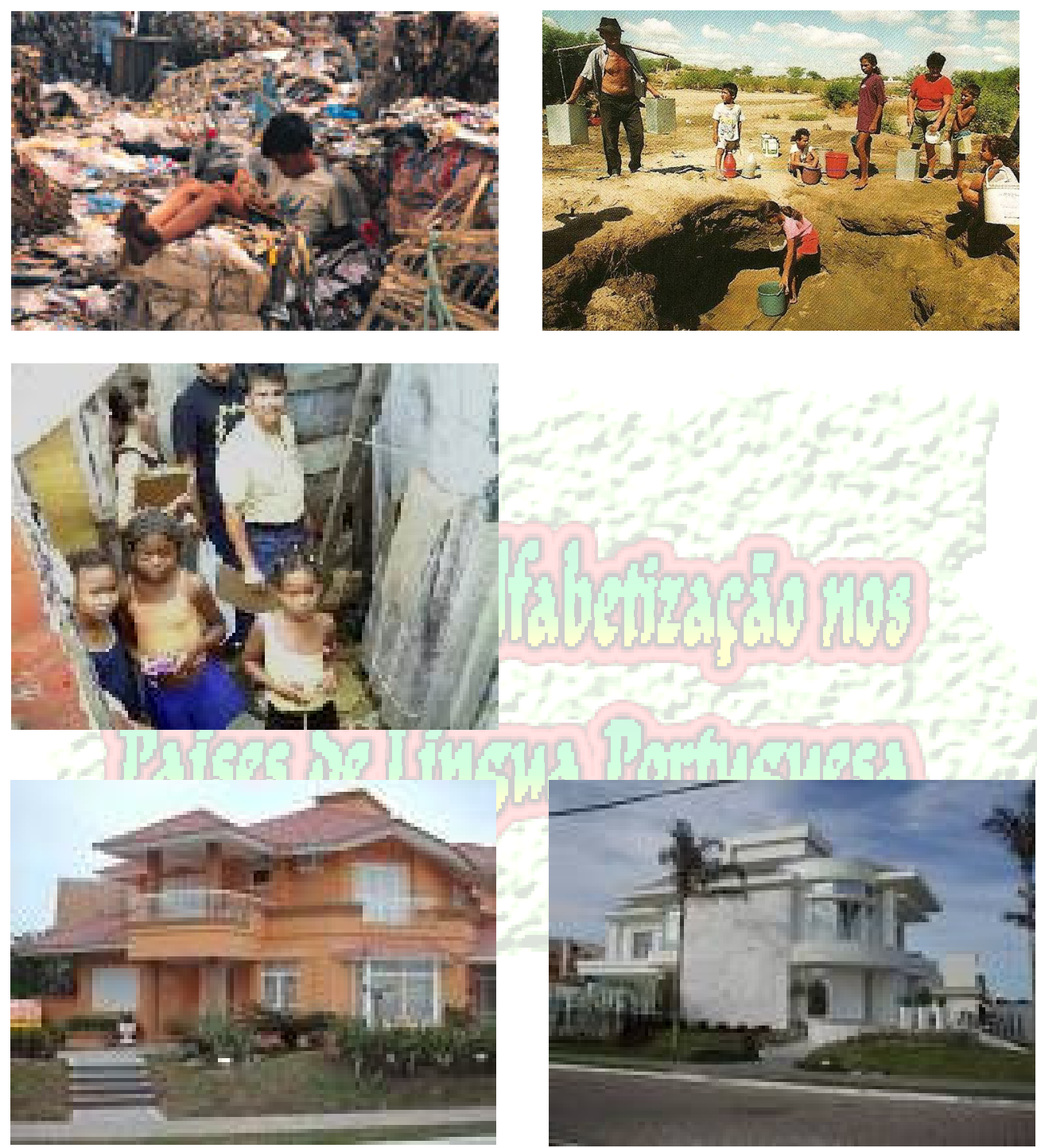
Predominância de bonecas, fantoches, bonecos confeccionados pelas crianças e personagens dos livros de cor branca em escola particular de São Paulo:
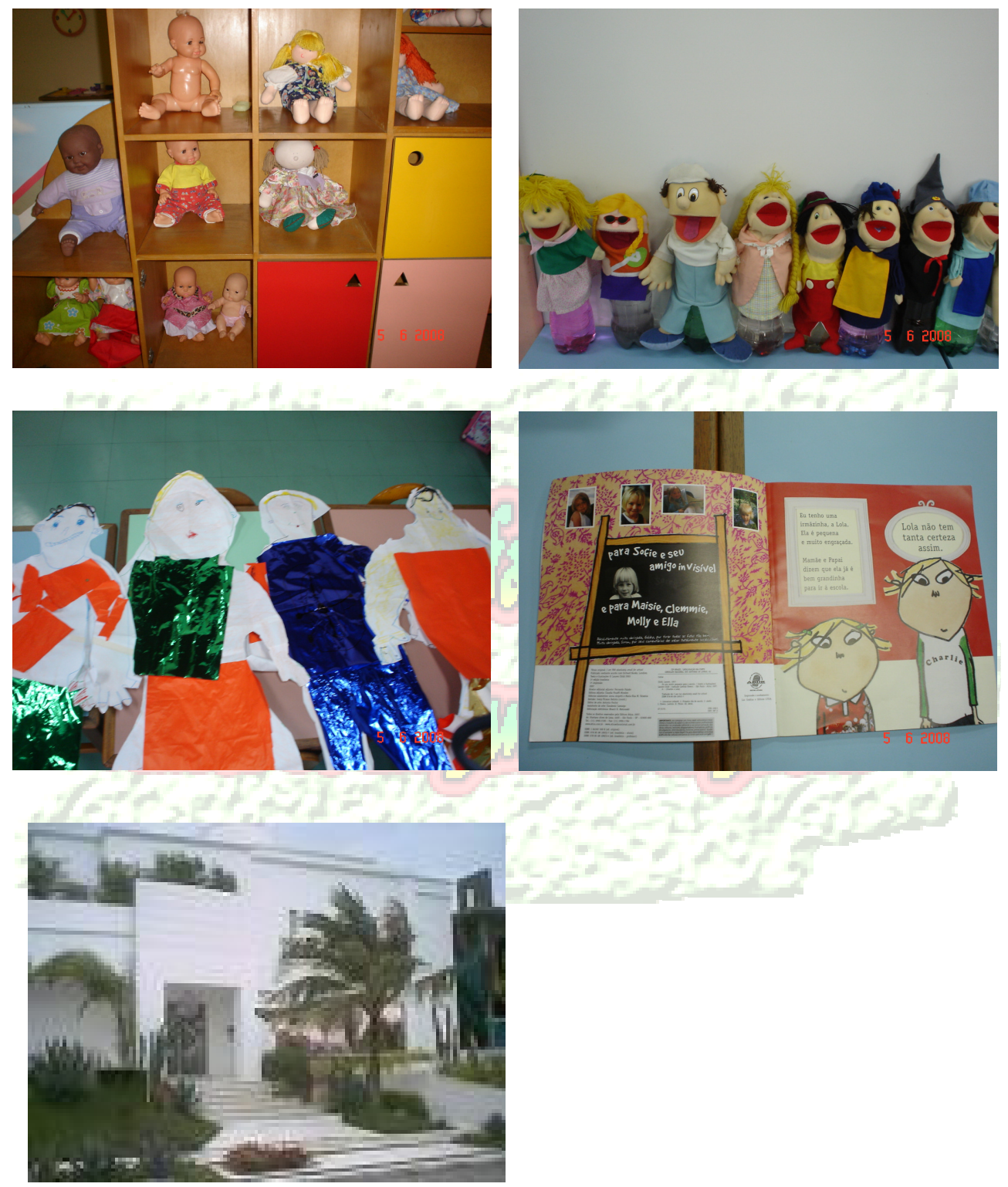


\section{FOTOS- BLOCO 8}

Créditos: Anita Cohn e Júlia Cravo

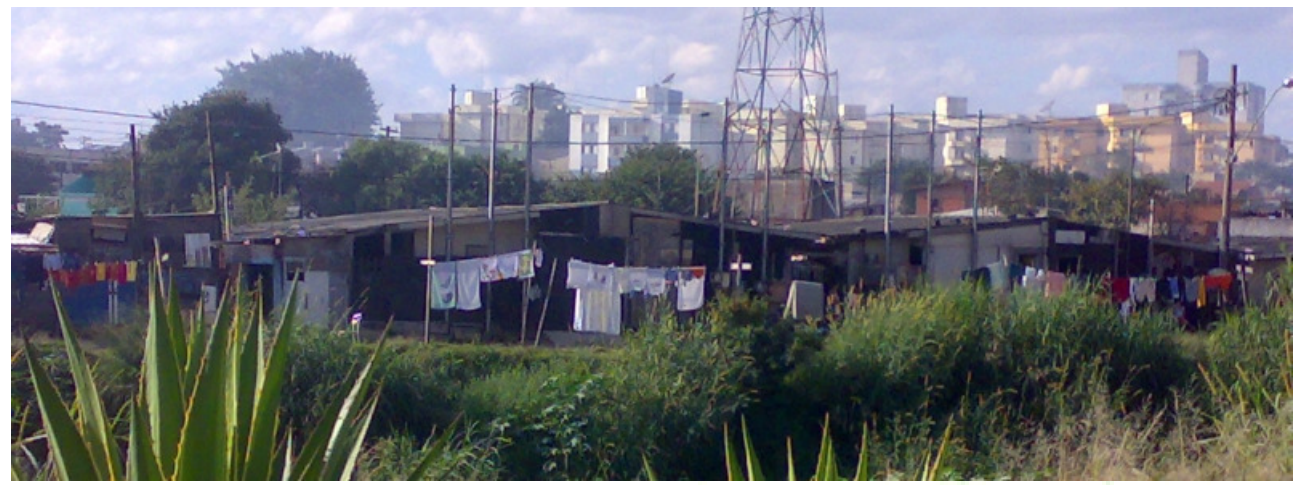

Fig. 1

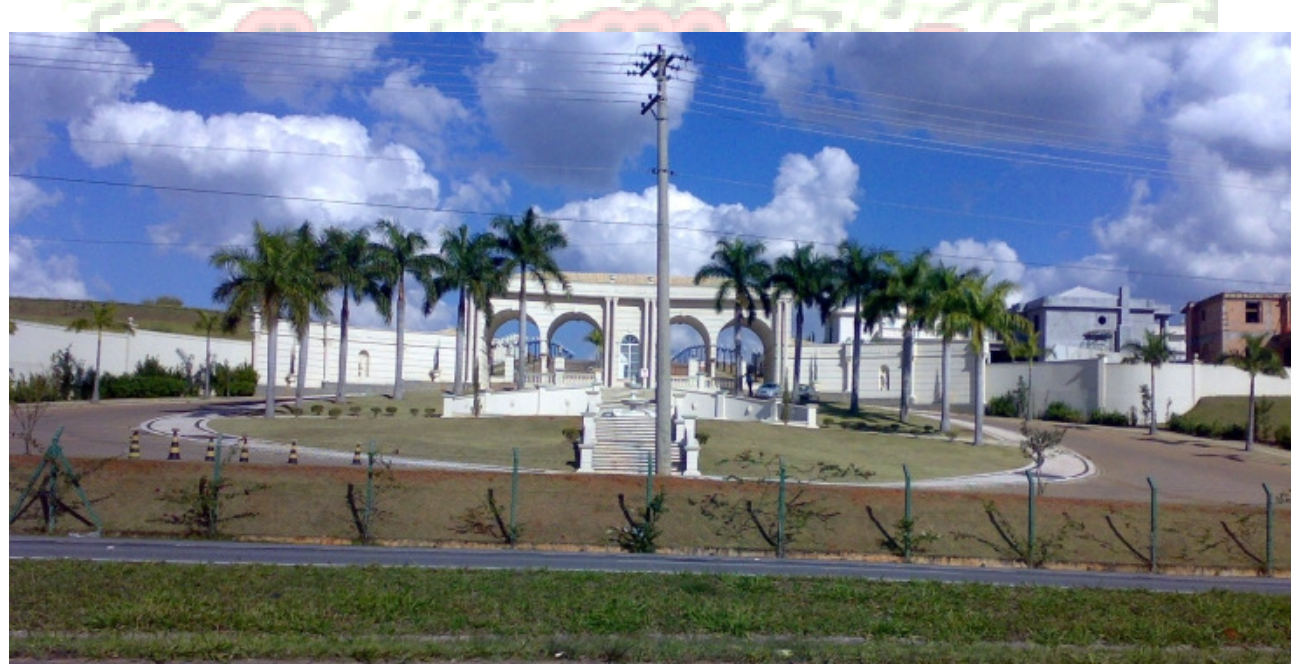

Fig. 2

Figuras 1 e 2: favela e condomínio de luxo, respectivamente, localizados não muito distantes na cidade de Jundiaí-SP 


\section{FOTOS- BLOCO 9}

Créditos: Milena Macedo, Fernanda Abrusio, Isabel Nascimento e Monica Souza
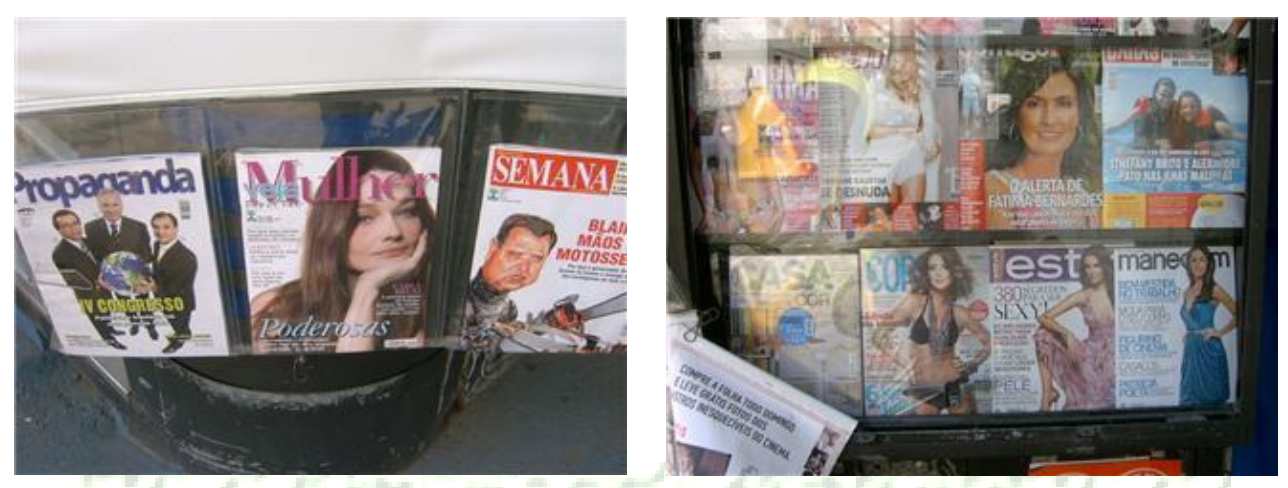

As fotos 1 e 2 foram tiradas em uma banca. Nelas aparecem várias capas de revistas famosas, mas em nenhuma aparece pessoa negra.

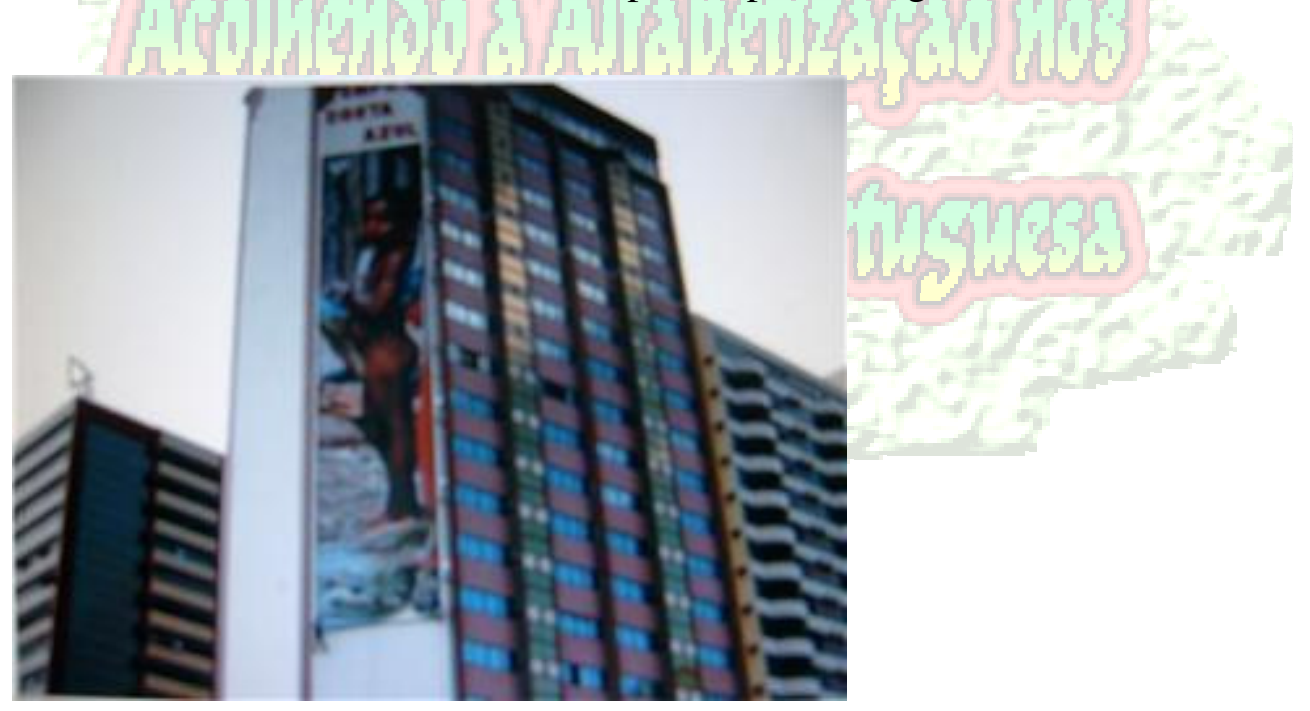

Foto encontrada em uma reportagem sobre a valorização da cultura e povo afro-descendentes realizada no Nordeste. Foram espalhadas pelas ruas fotos de pessoas negras desconhecidas. 


\title{
BLOCO 10: ISIS MEGUMI INAFUKU
}

\author{
Natália Dresser Zago
}

\section{O universo dos brinquedos é branco}

As fotos a seguir foram tiradas em uma loja de brinquedos (Hi Happy) e em uma loja de departamentos (Americanas), ambas nos shoppings da cidade de Santo André.

Pudemos observar que a maioria das bonecas é branca, mas não somente isso, a maioria tem cabelos louros.

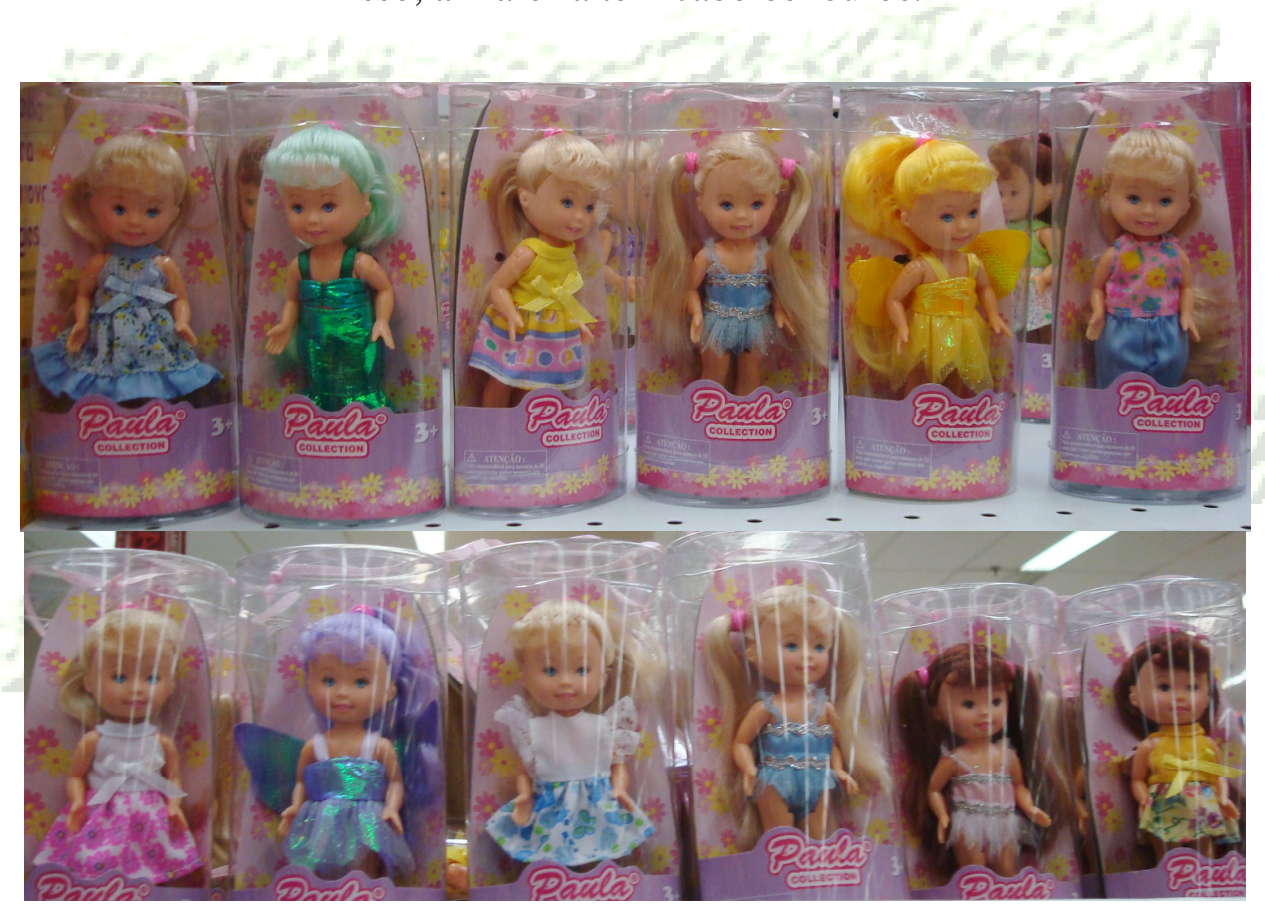




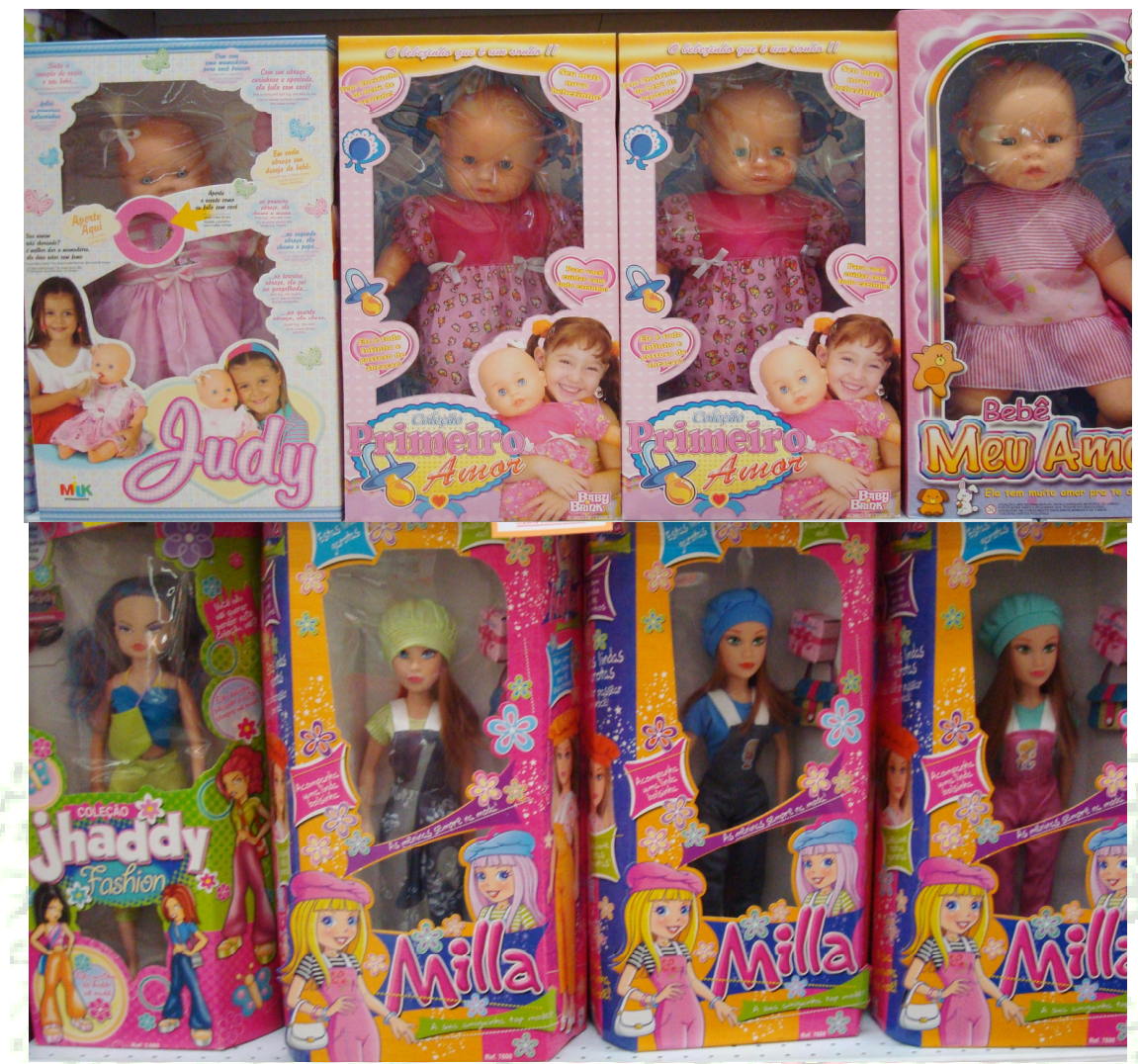

Encontramos sim bonecas negras, mas geralmente era apenas uma boneca negra, cercada de muitas outras brancas. Havia várias bonecas brancas de um mesmo modelo, diferindo nas roupas e na cor do cabelo, mas apenas uma boneca da cor negra. 

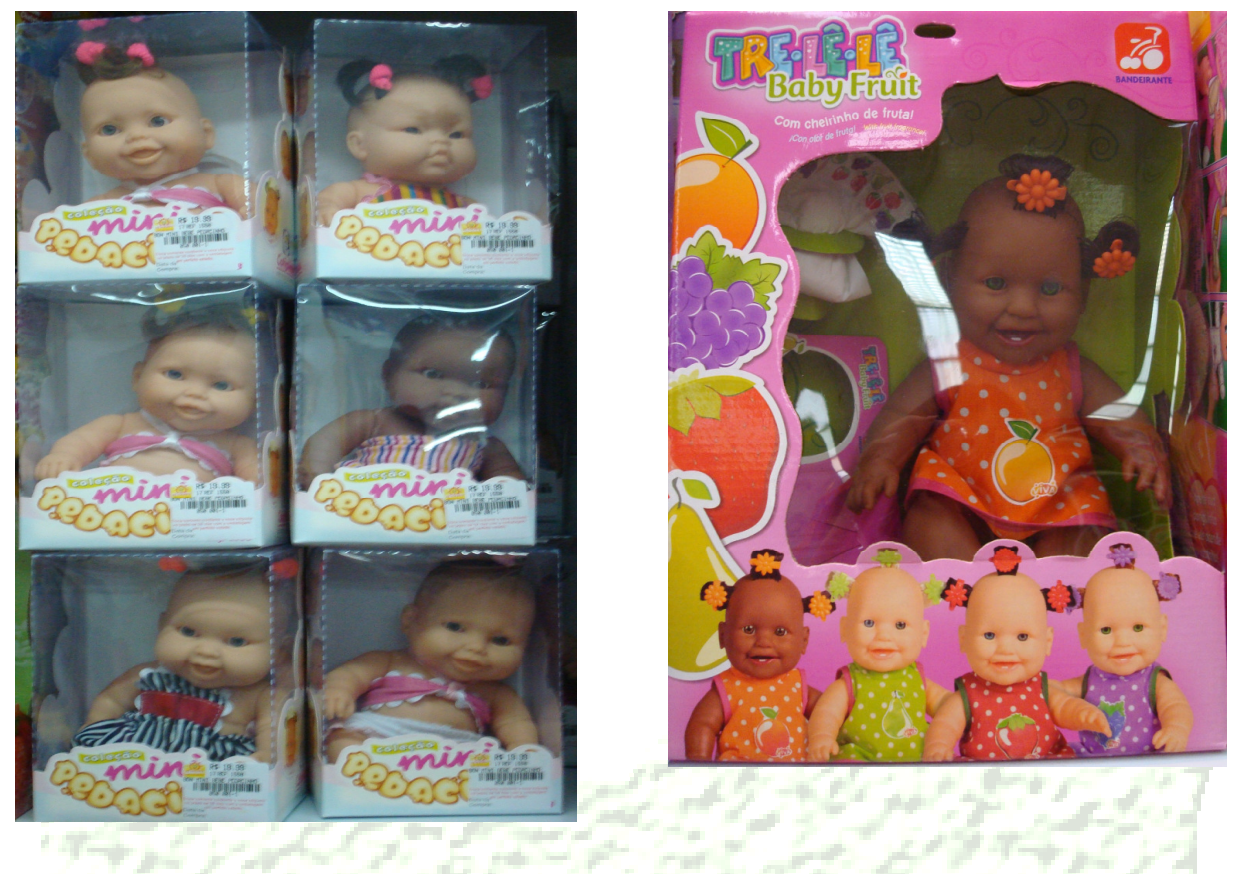

Quando observamos as bonecas de tamanho "real", notamos que não há nenhuma negra.

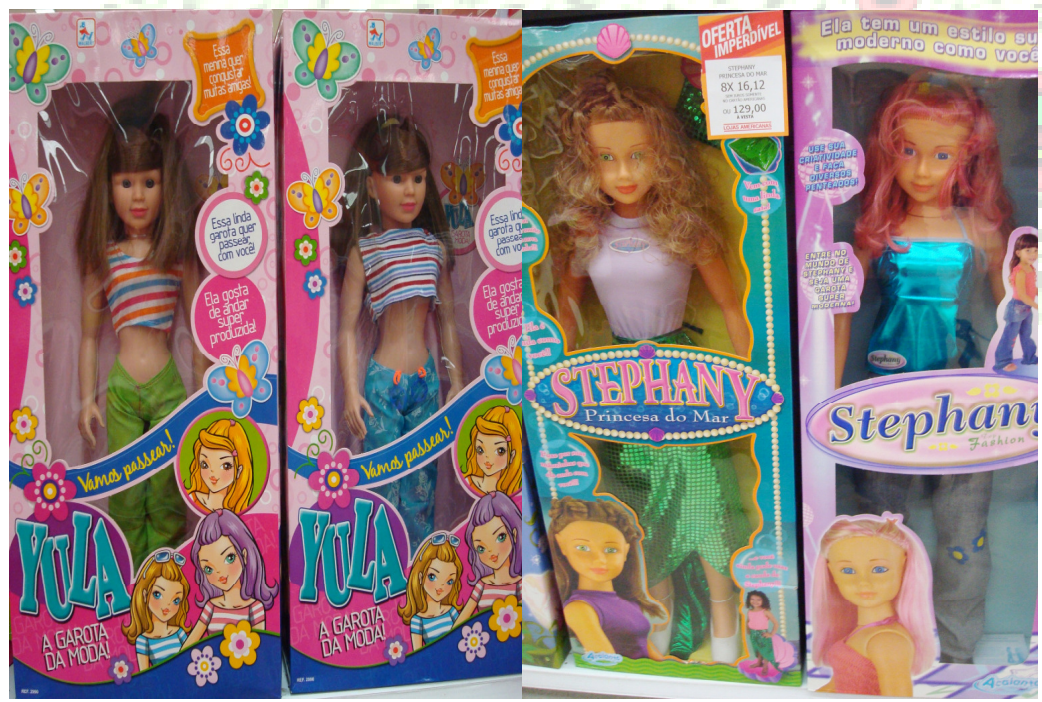

E estas são as fotos mais intrigantes: 


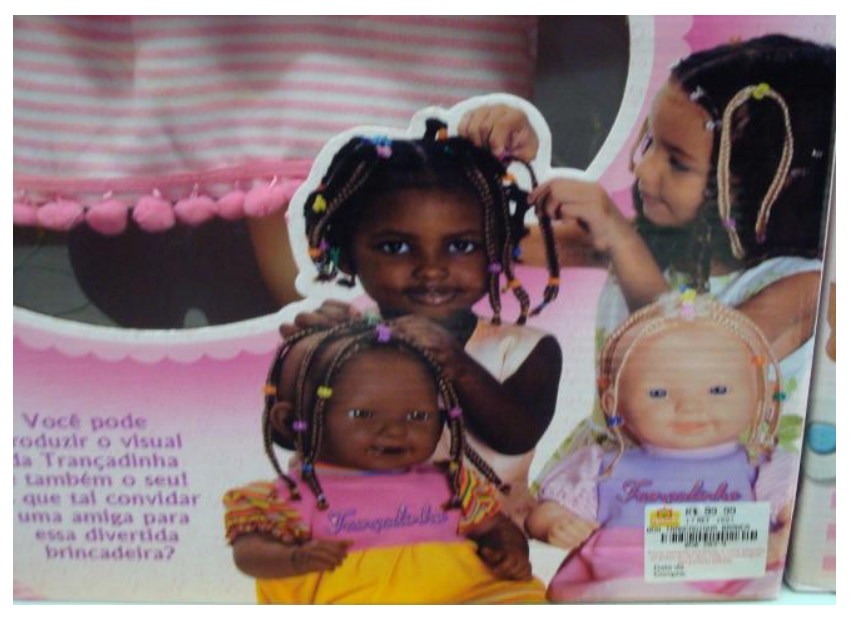

A única foto em que uma criança branca interage com uma negra, mas mesmo assim ainda mostra o que já havíamos observado, cada criança com a boneca da "sua raça".

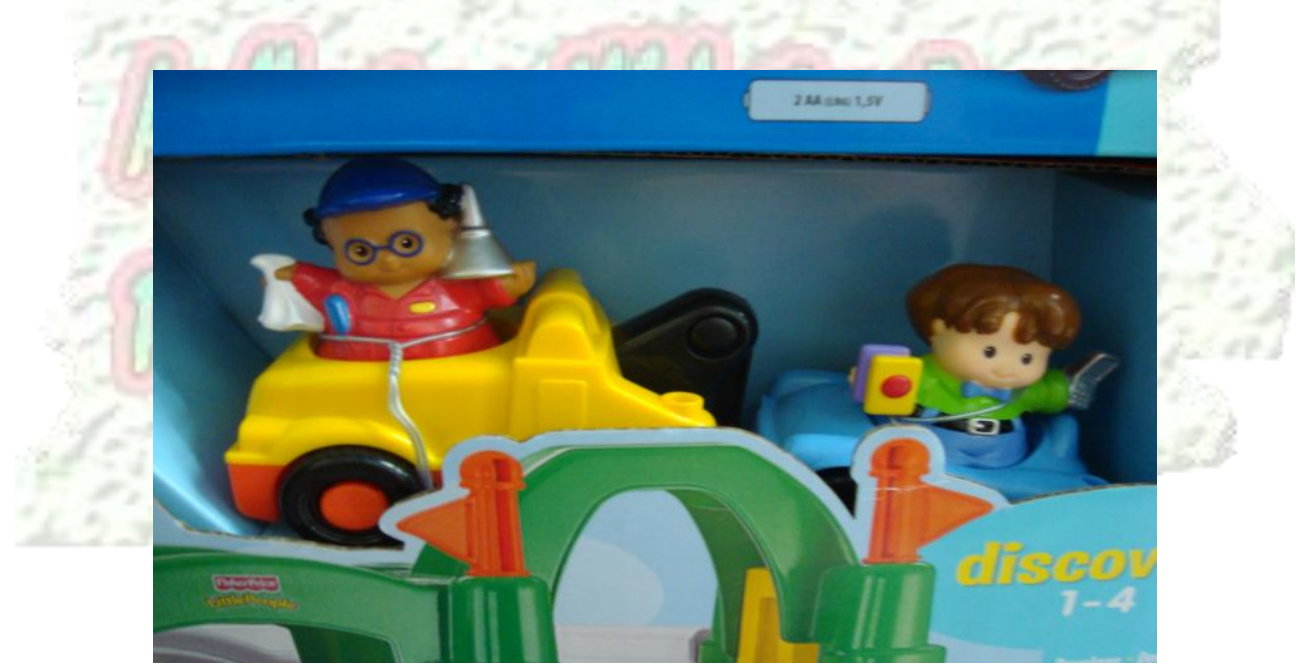

Esse brinquedo mostra um boneco negro como mecânico, segurando um funil e um pedaço de pano, e um boneco branco como dono do carro a ser consertado, com um celular na mão e roupa social.

Podemos notar que o brinquedo é recomendado para crianças entre um e quatro anos, assim sendo, logo na primeira infância, elas são inseridas numa visão de mundo preconceituosa. 


\section{BLOCO 12}

\section{Nathalia Fernandes Soares}

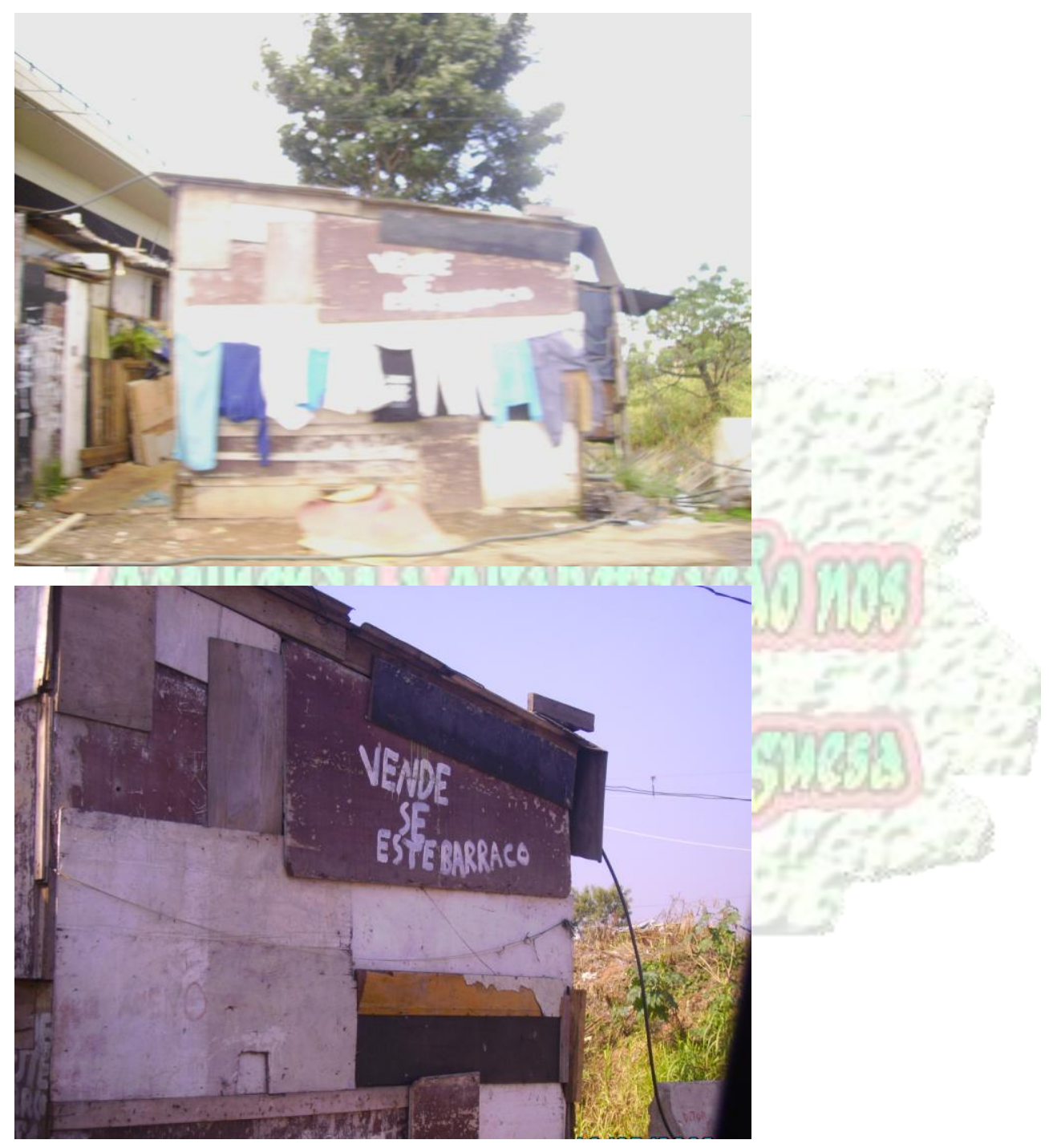

Foto de moradia a venda na Marginal Tietê, São Paulo, SP. 

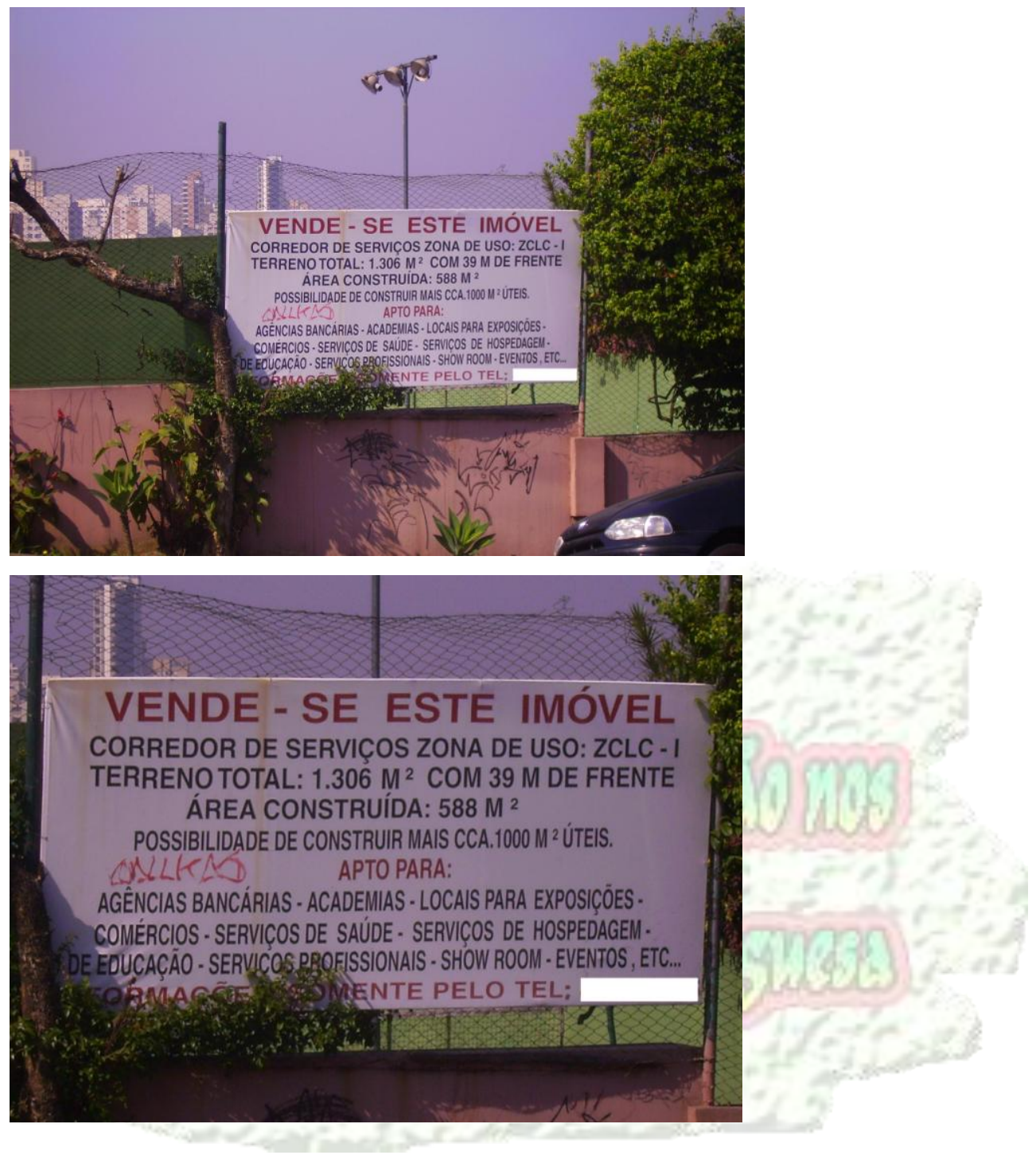

Foto de imóvel a venda na Zona Oeste de São Paulo, SP.

Através dessas imagens procurei retratar a diferença de condição econômica existente na nossa sociedade, a qual também faz parte da realidade de outros países pertencentes ao mundo lusófono. As duas primerias fotos referem-se a uma moradia localizada na Marginal Tietê, Zona Leste da cidade de São Paulo, em uma pequena favela que foi crescendo ao lado de um hipermercado famoso e a frente de prédios do projeto "Cingapura", o qual atendeu moradores 
que residiam em algumas favelas da cidade de São Paulo. As duas últimas fotos são de um imóvel localizado na Zona Oeste de São Paulo, em uma rua com casas luxuosas e uma visão privilegiada dos arredores.

Fica claro, através do anúncio de venda, as diferentes realidades, condições e perspectivas que cada proprietário possui, diferença esta bastante conhecida entre os sujeitos do Mundo Globalizado.

\section{Bloco 13:}

Élita Paula do Nascimento Santos e Thalia M. Basílio

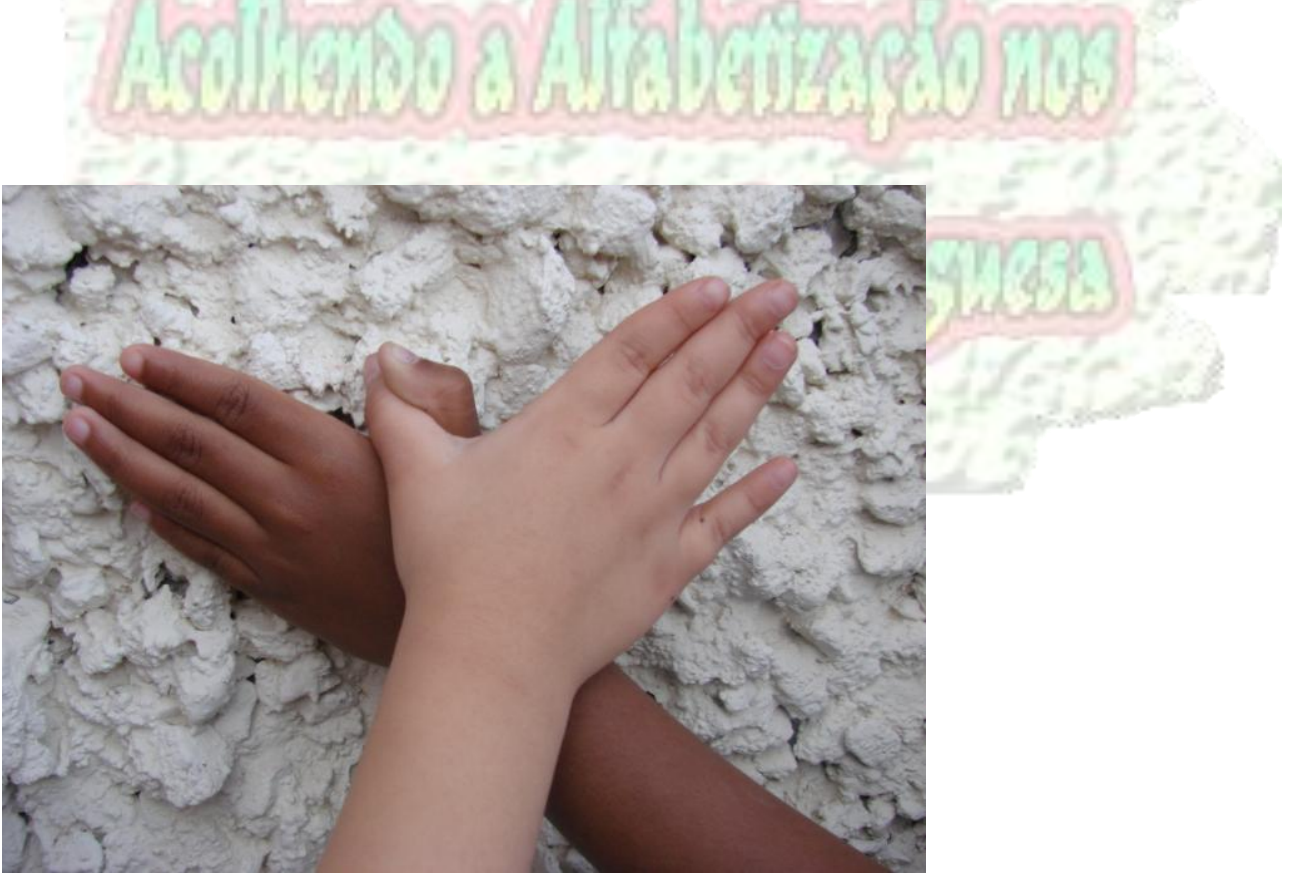




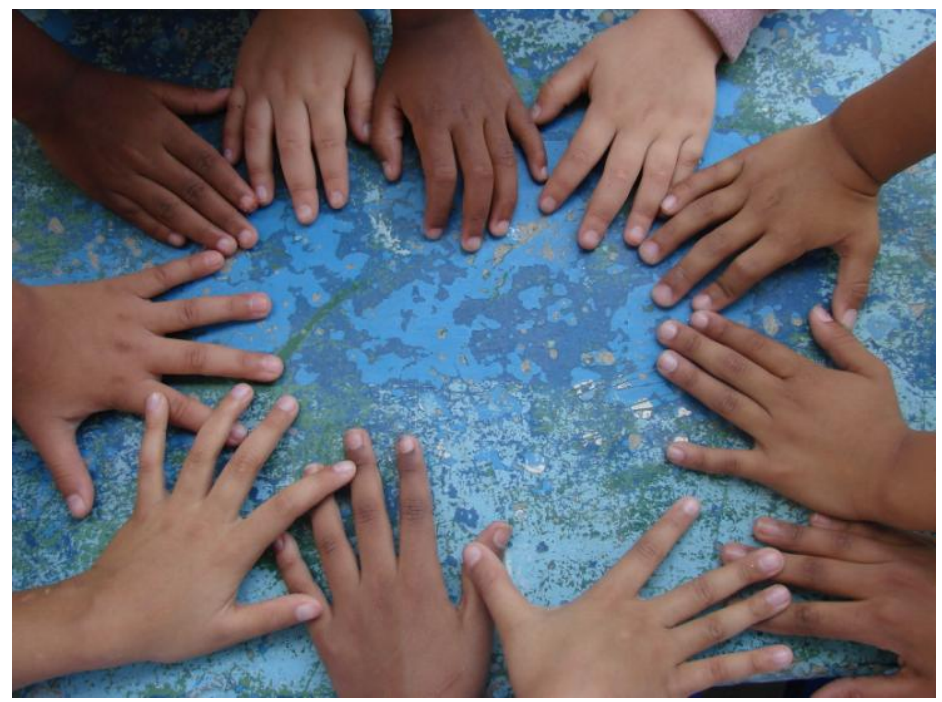

\section{C: Fotos acerca do uso da Língua Portuguesa na cidade de São Paulo.}

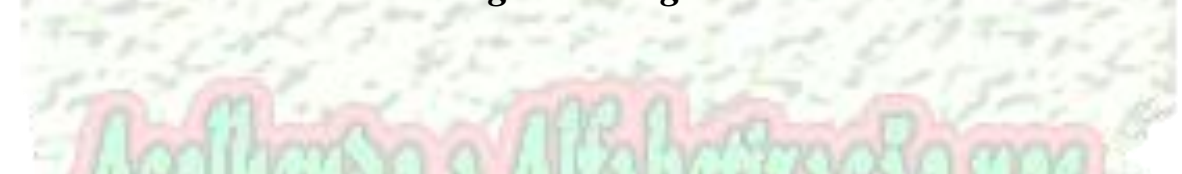

FOTOS- BLOCO 1

Créditos: Carolline Ribeiro Lacerda, Manoela Ribeiro Paixão e Mirna Collazingari Barbosa

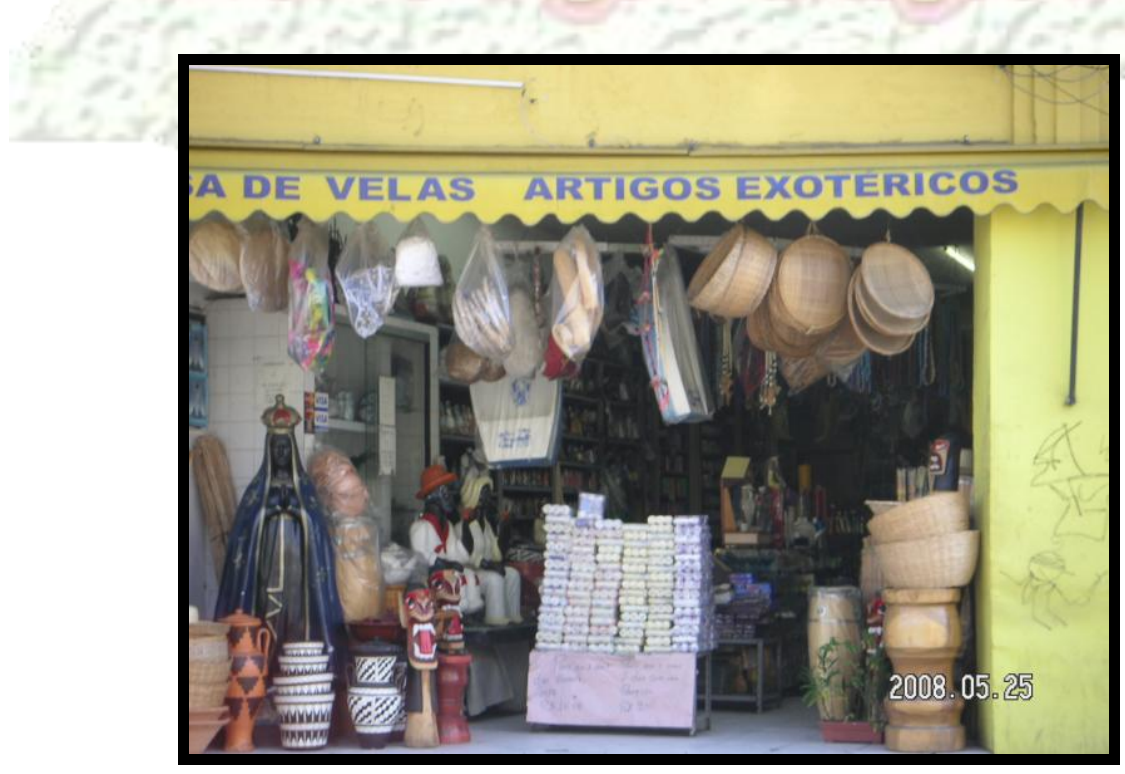




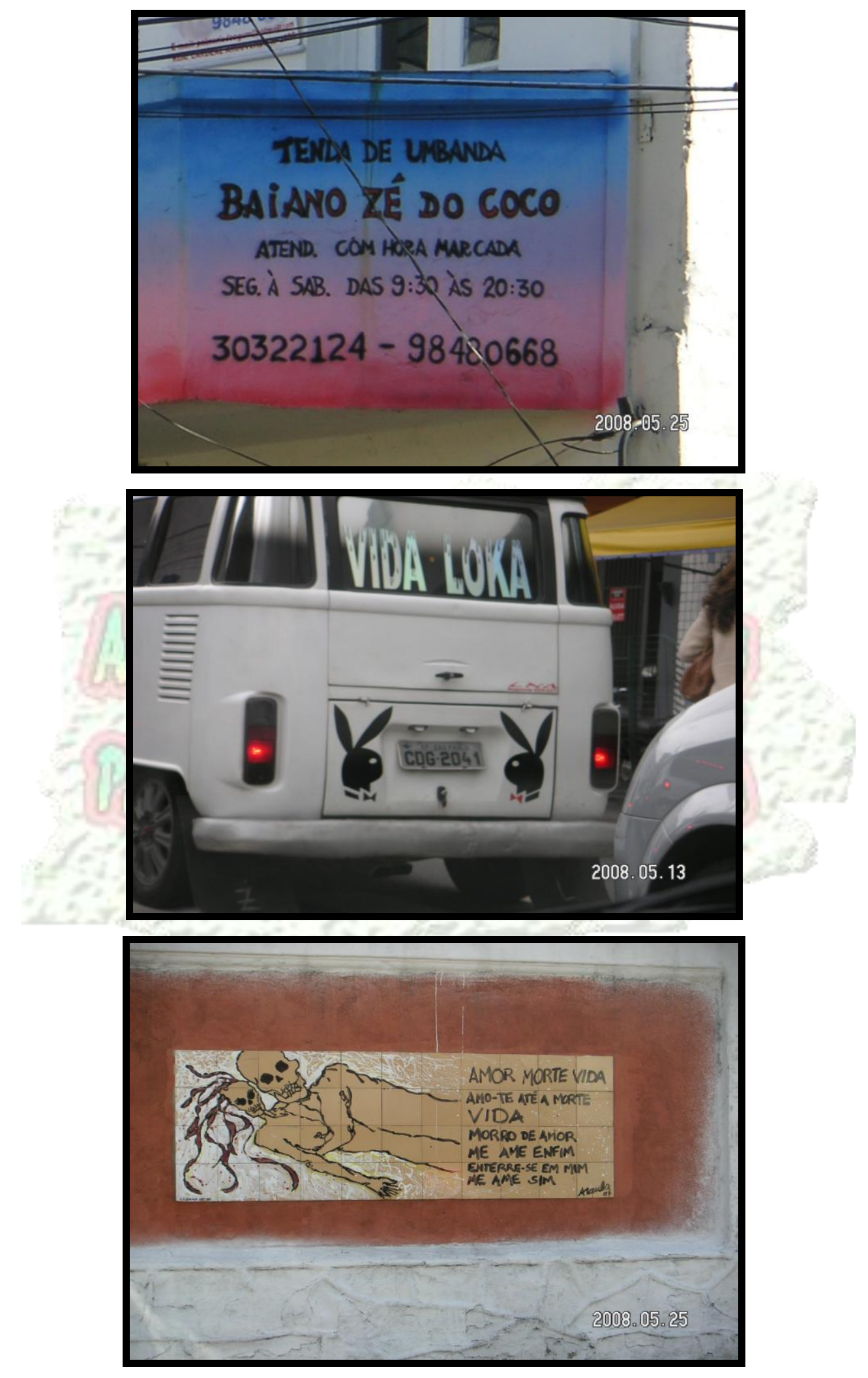



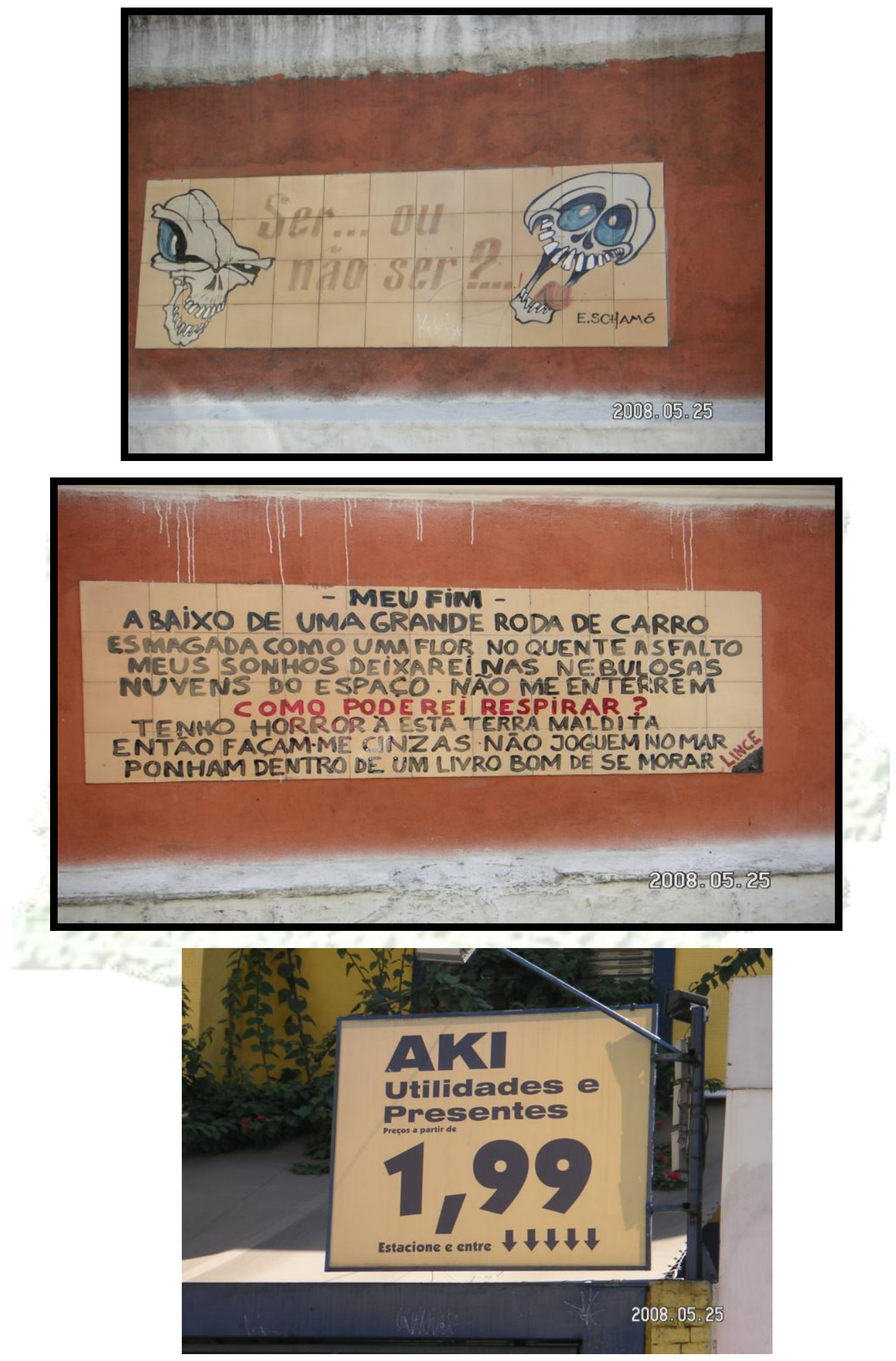


\section{FOTOS- BLOCO 2}

Créditos: Alessandra Silva Pinto
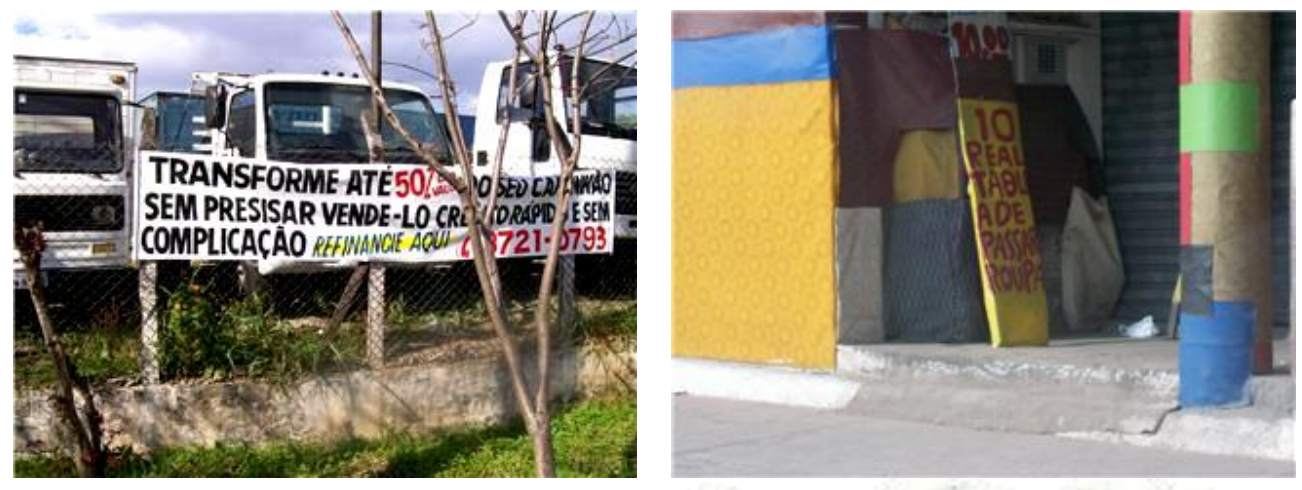

FOTOS- BLOCO 3

Créditos:Viviana Cukier

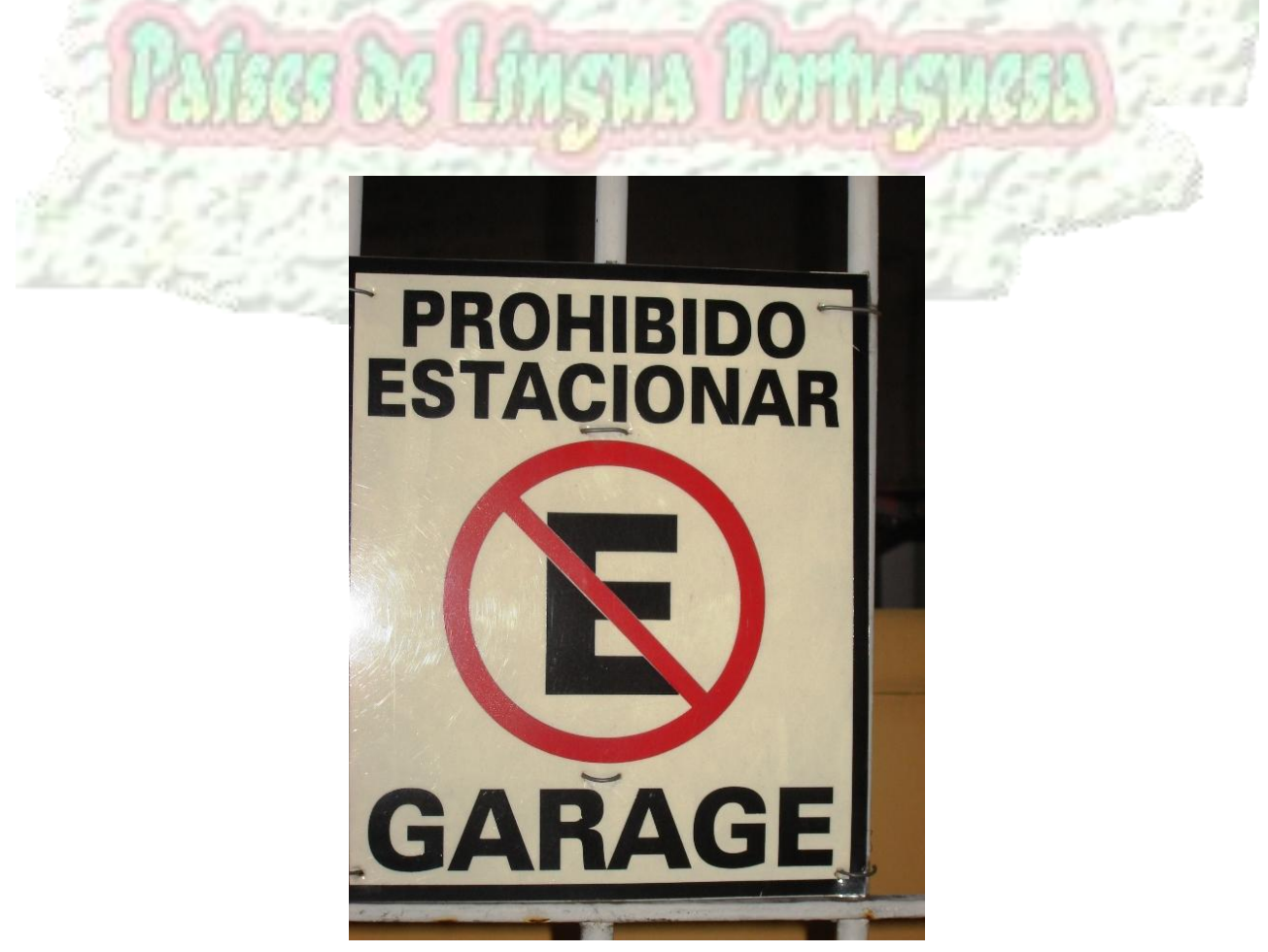




\section{FOTOS- BLOCO 4}

Créditos: Fernanda Inácio da Rosa

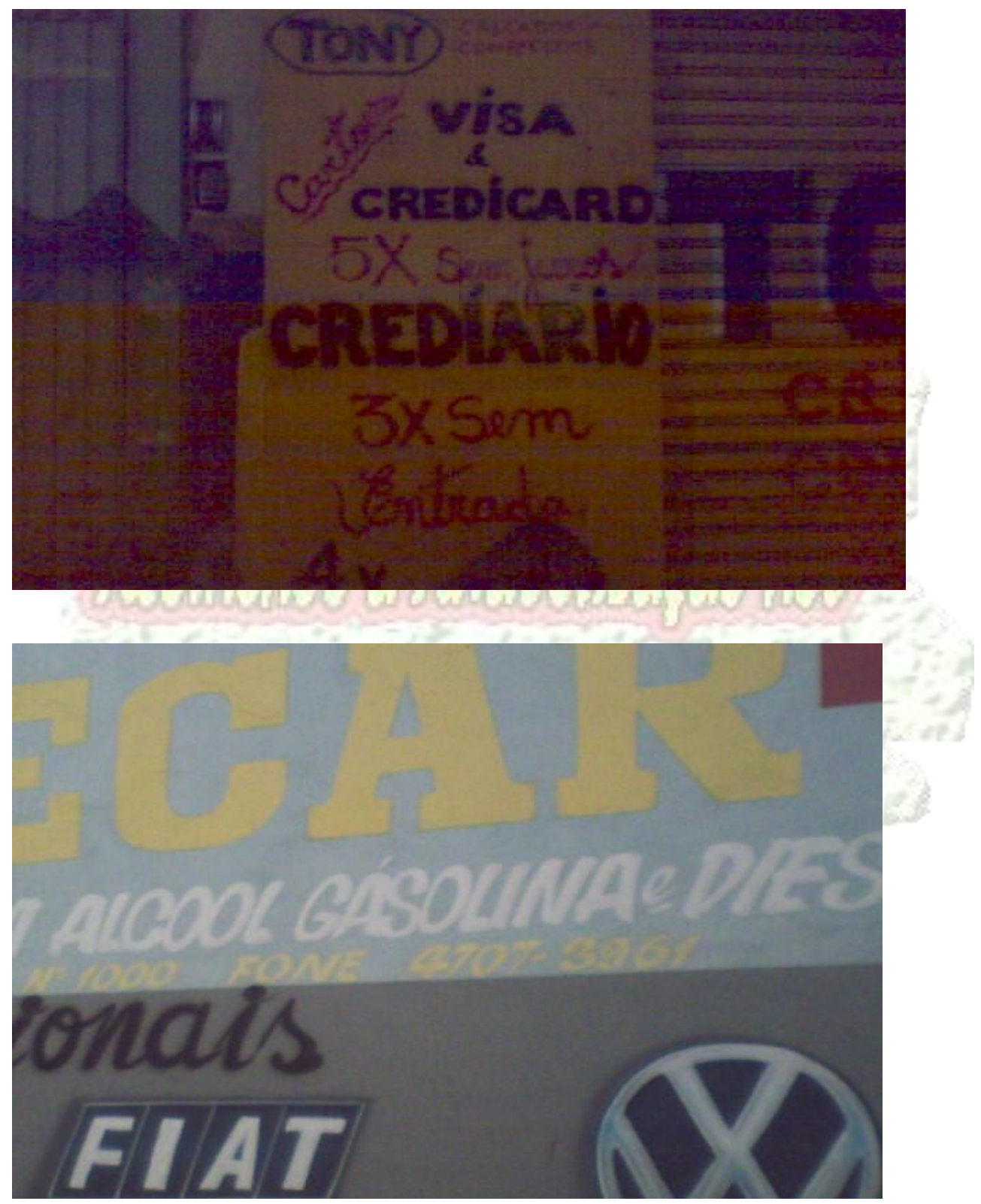



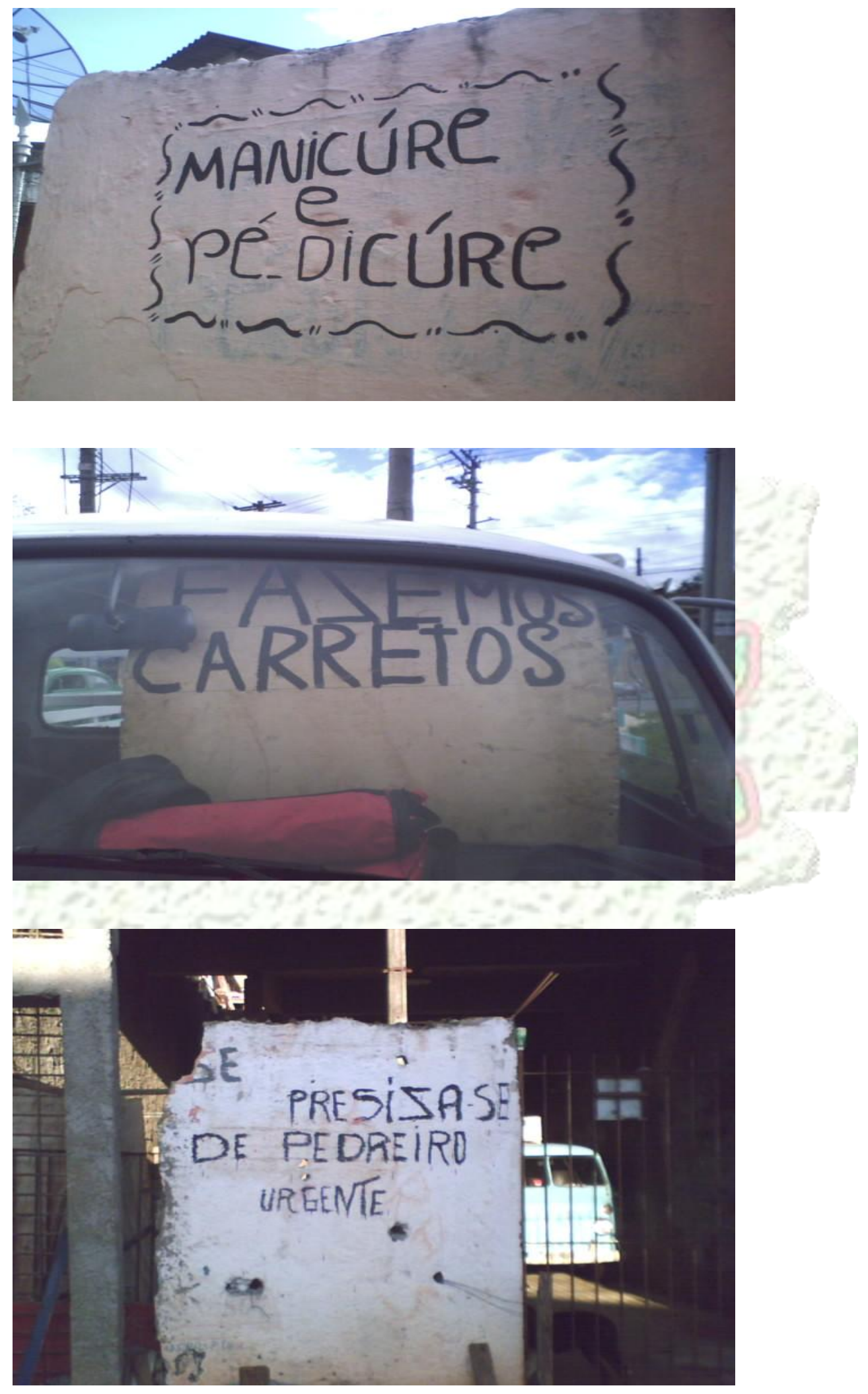

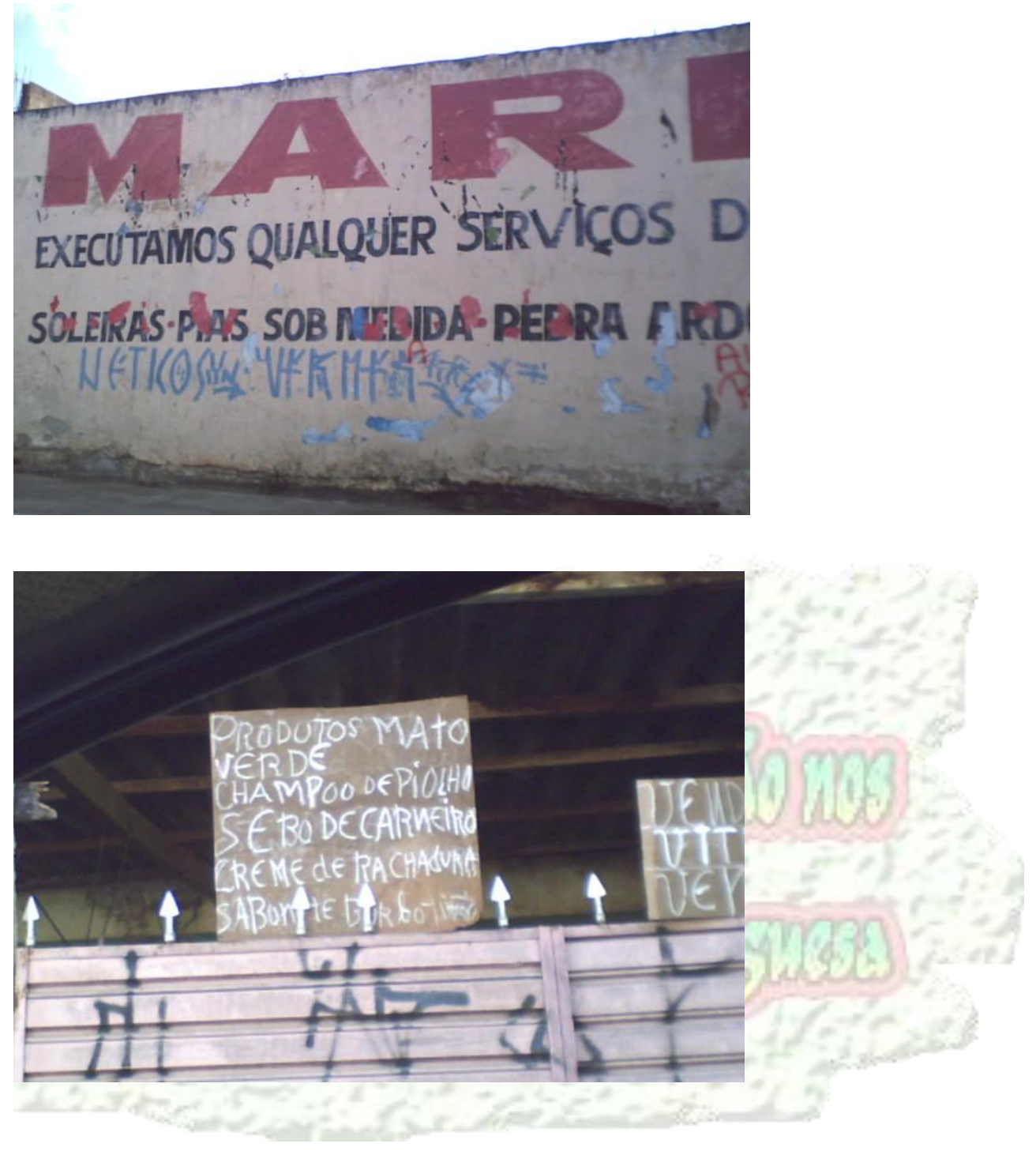


\section{FOTOS- BLOCO 5}

Créditos: Fernanda Carreira Mendes

Cláudia Lúcia Bernardes
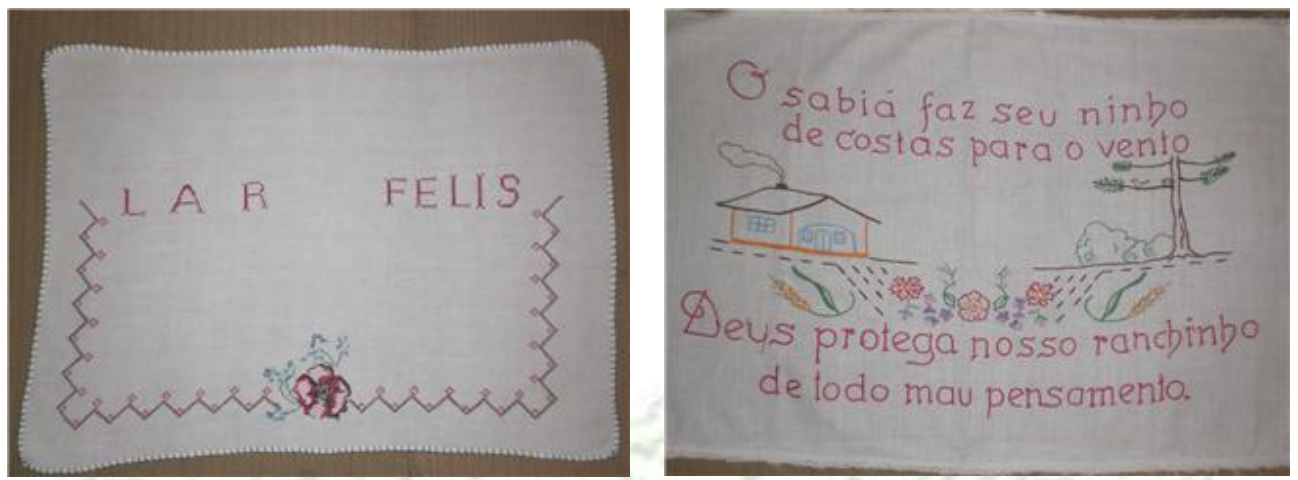

\section{BLOCO 6}

Créditos: Jacqueline Simões, Paulo Genovese, Vânia Daré e Viviane

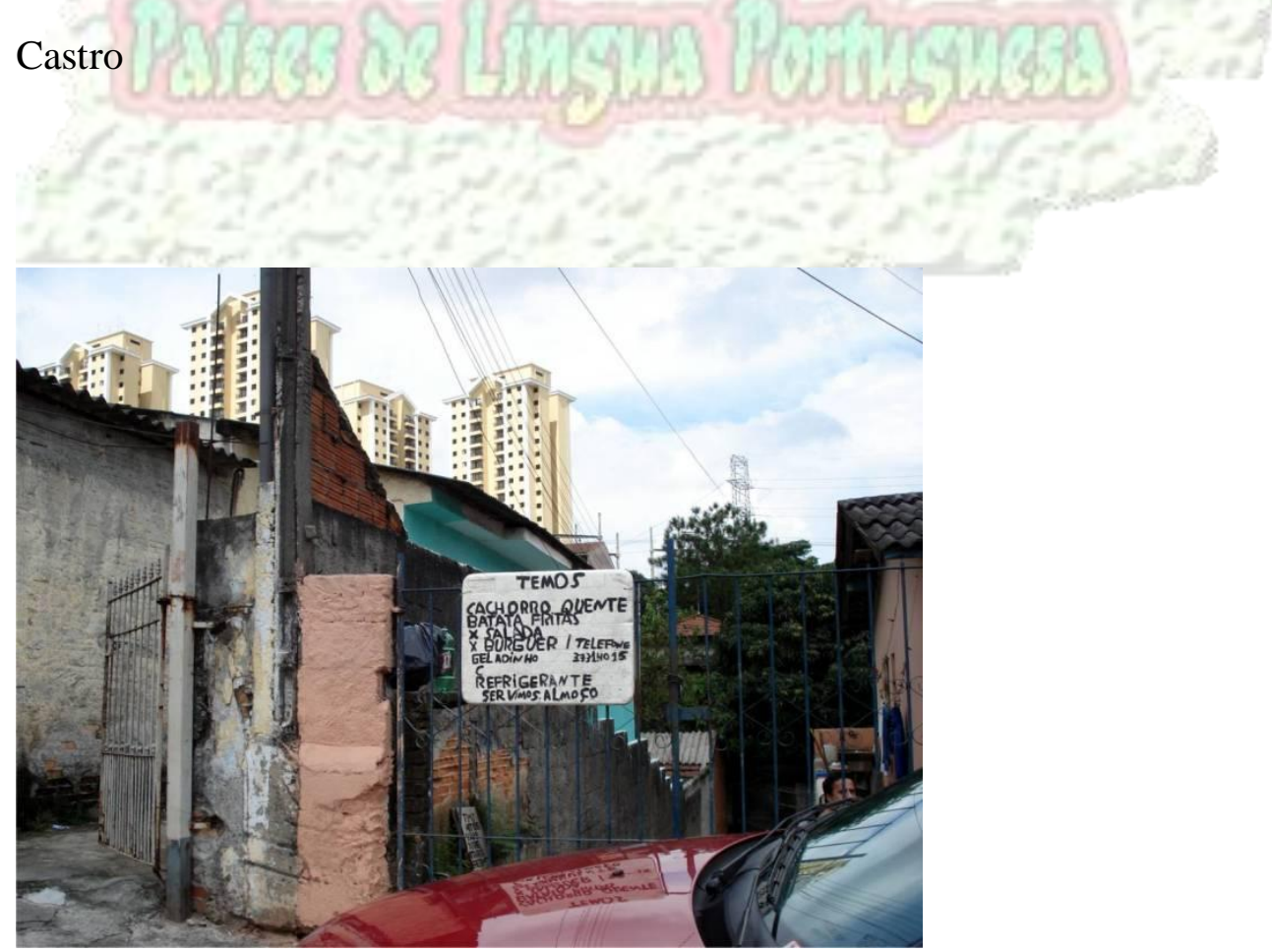



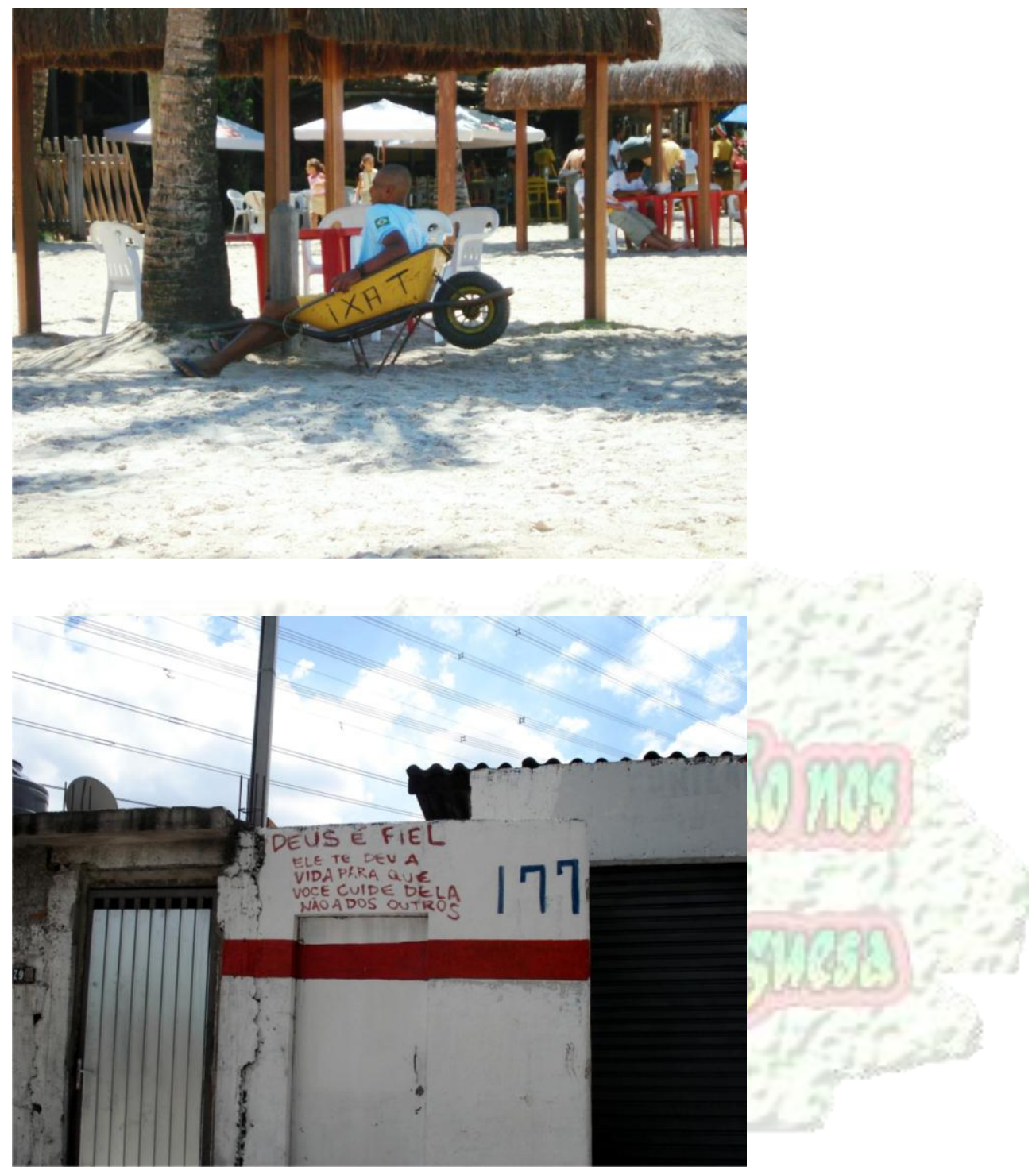


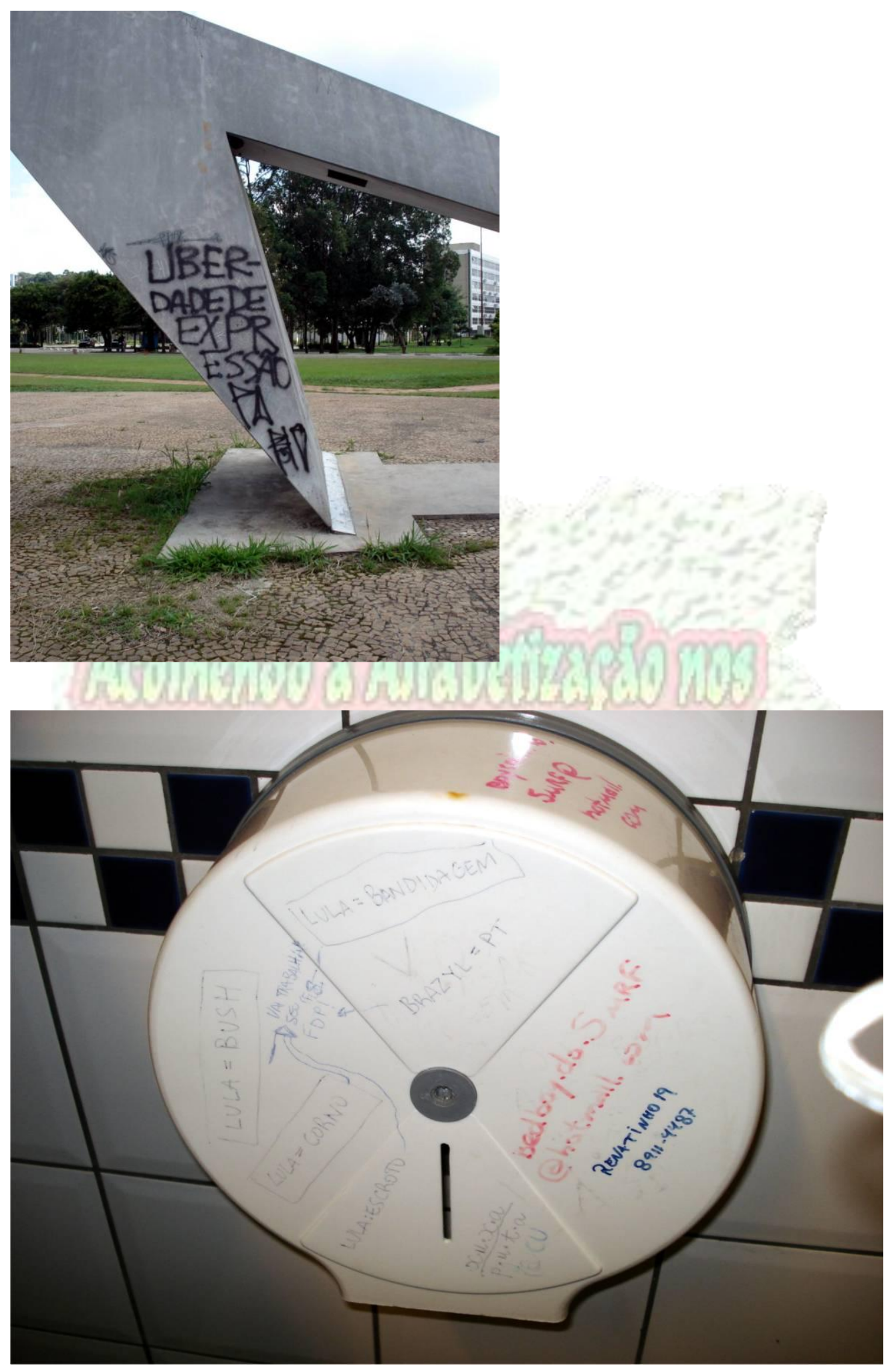




\section{FOTOS- BLOCO 7}

Créditos: Reinaldo Amaro Laudino
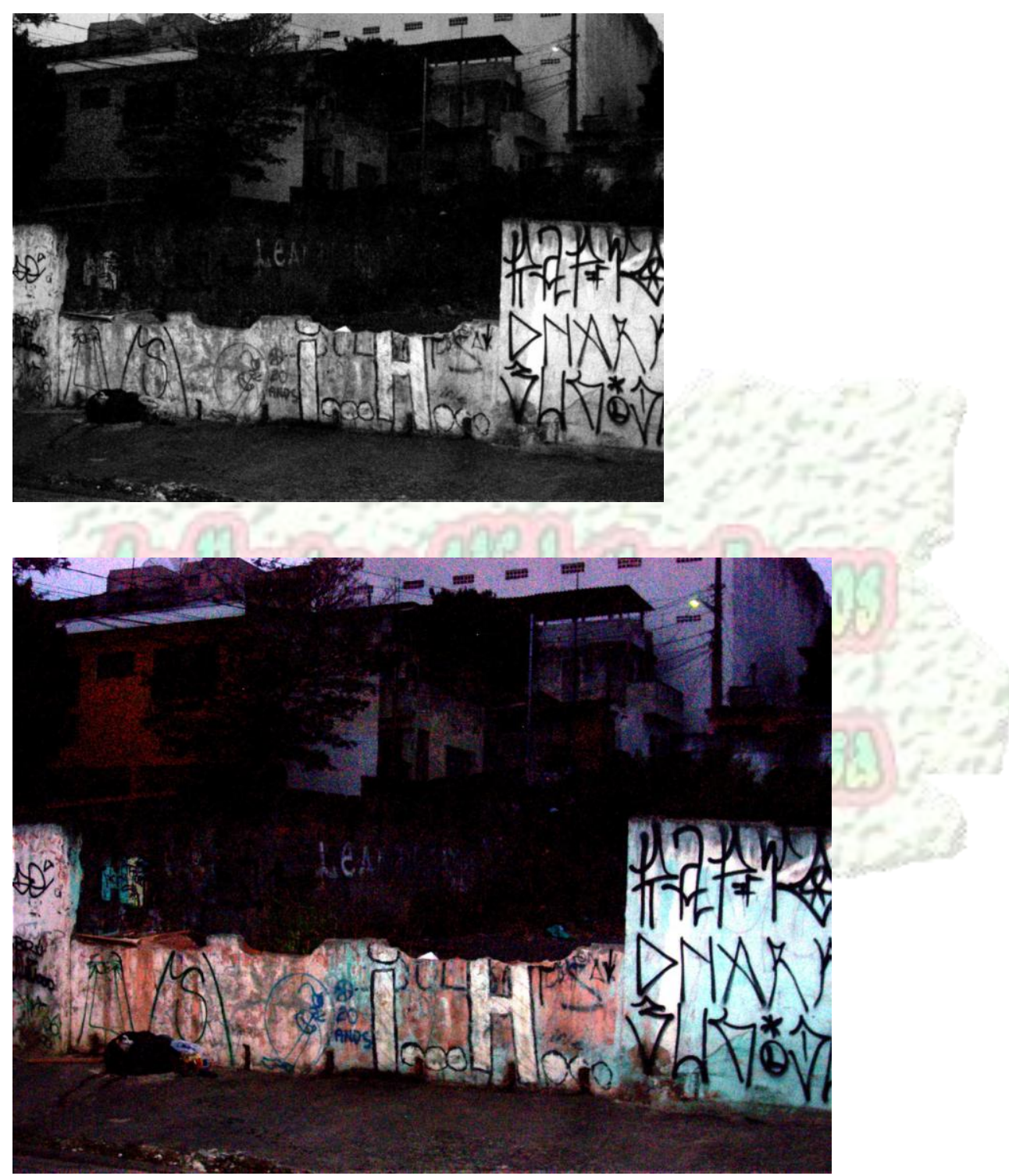

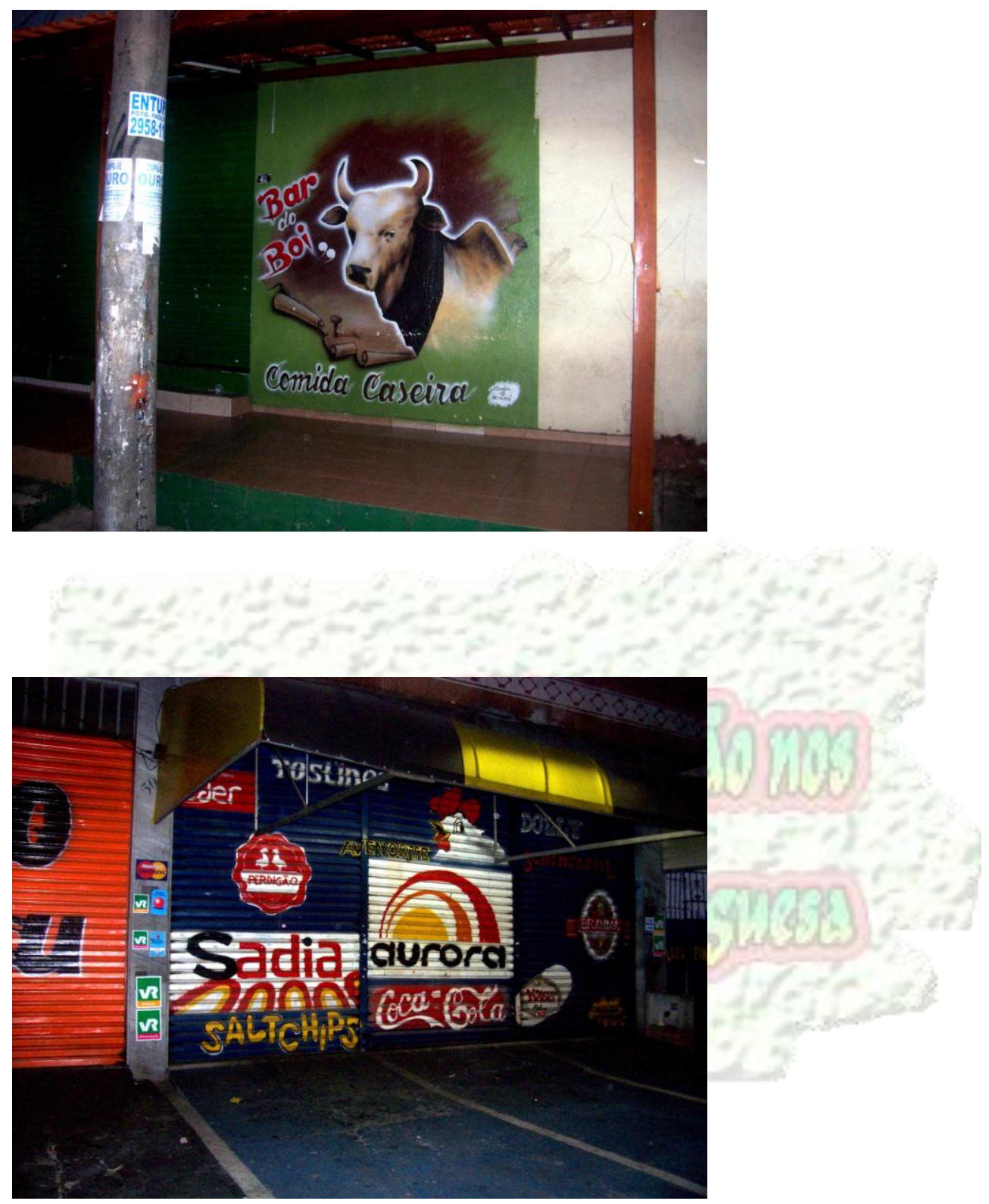

\section{FOTOS- BLOCO 8}

Créditos: Adriana Santos Rodrigues da Silva, Ana Beatriz de Medeiros

Pereira, Aryadne de Moraes Fernandes da Silva, Maria Cláudia Ligori Figueiredo e Thaís Ginícolo Cabral 


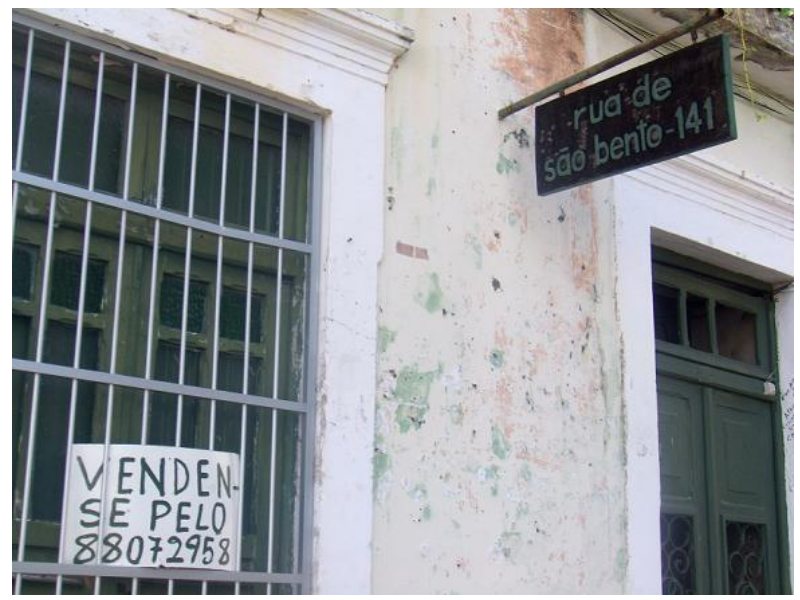

Foto contendo erro ortográfico, tirada em Recife/2008

FOTOS- BLOCO 9

Créditos: Débora Thais Sales dos Santos

Placas com erros ortográficos na cidade de São Paulo:

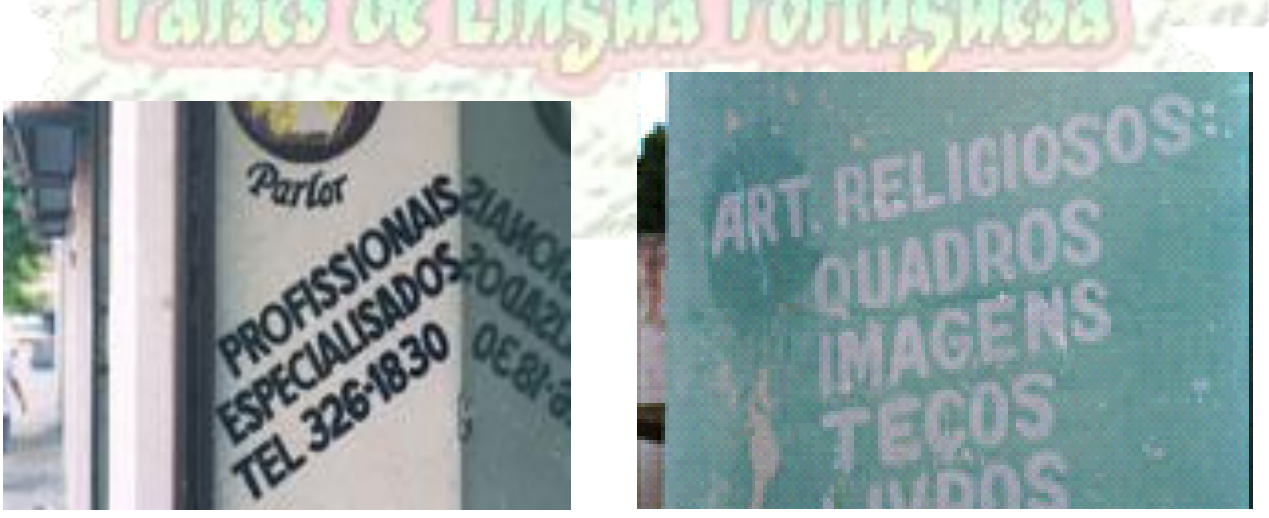



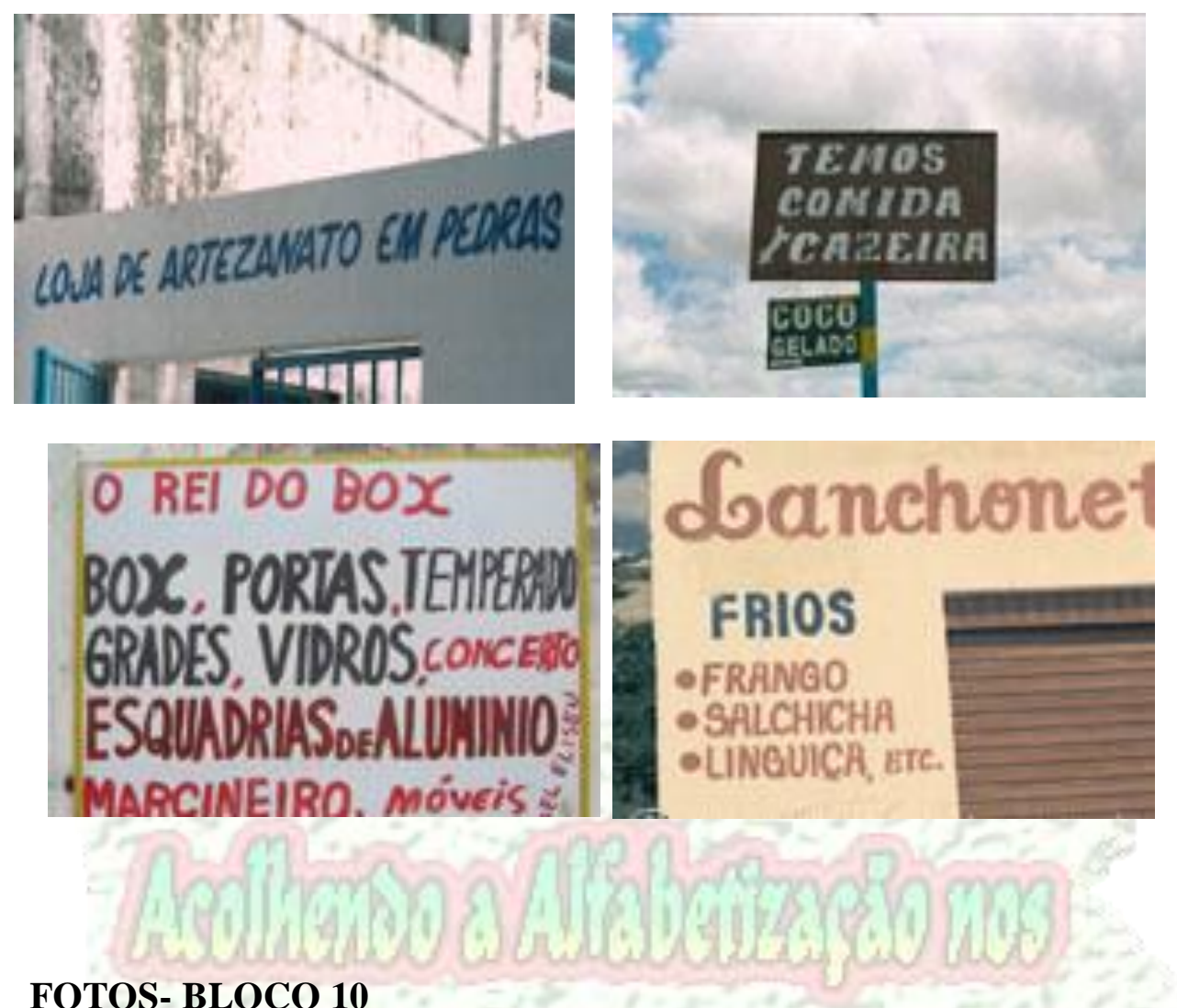

FOTOS- BLOCO 10

Créditos: Renata Paschoalotto da Silva

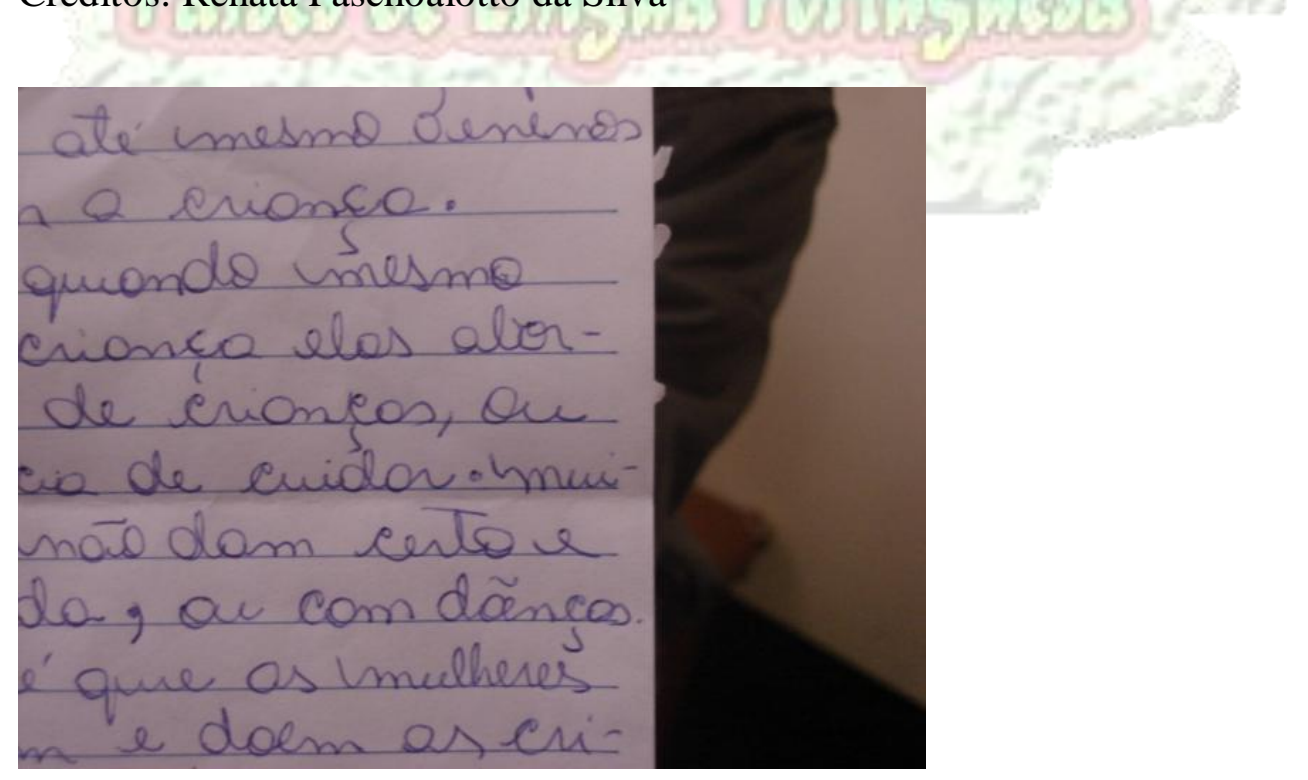

Redação sobre o tema aborto: Repare na escrita da palavra "doenças". 


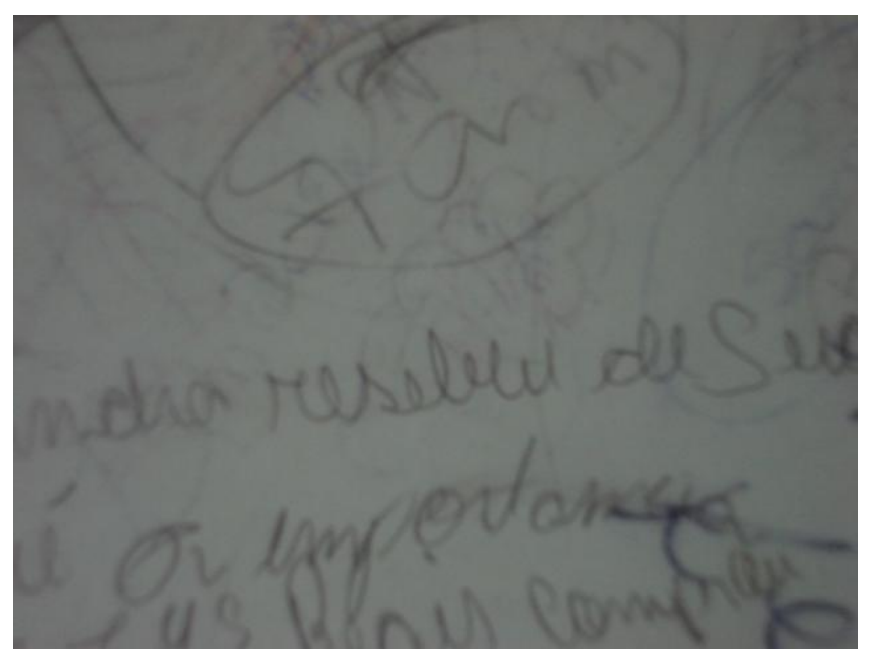

Escritos em carteira: "Recebeu" com "s".

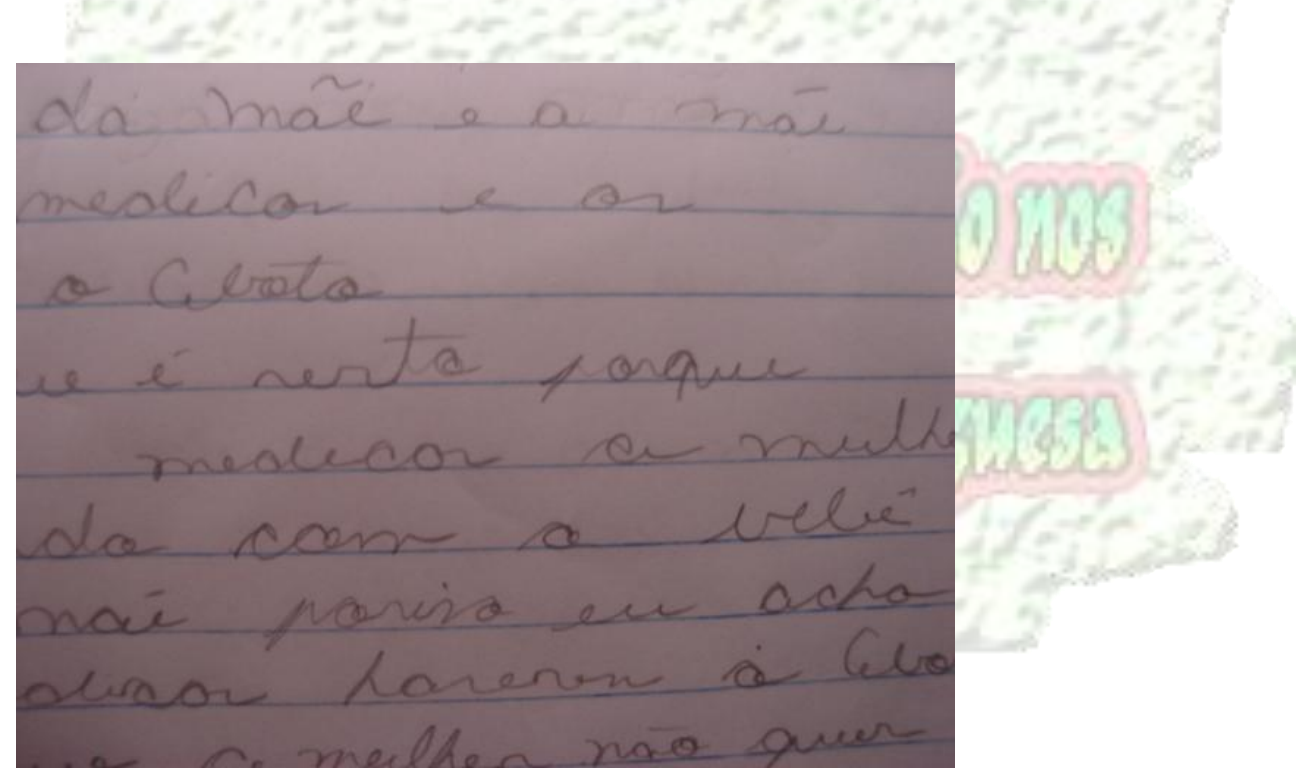

Redação sobre o tema aborto: o jovem escreveu "poriso" = por isso / "aboto" = aborto. 


\section{FOTOS- BLOCO 11}

Créditos: Marina Dias

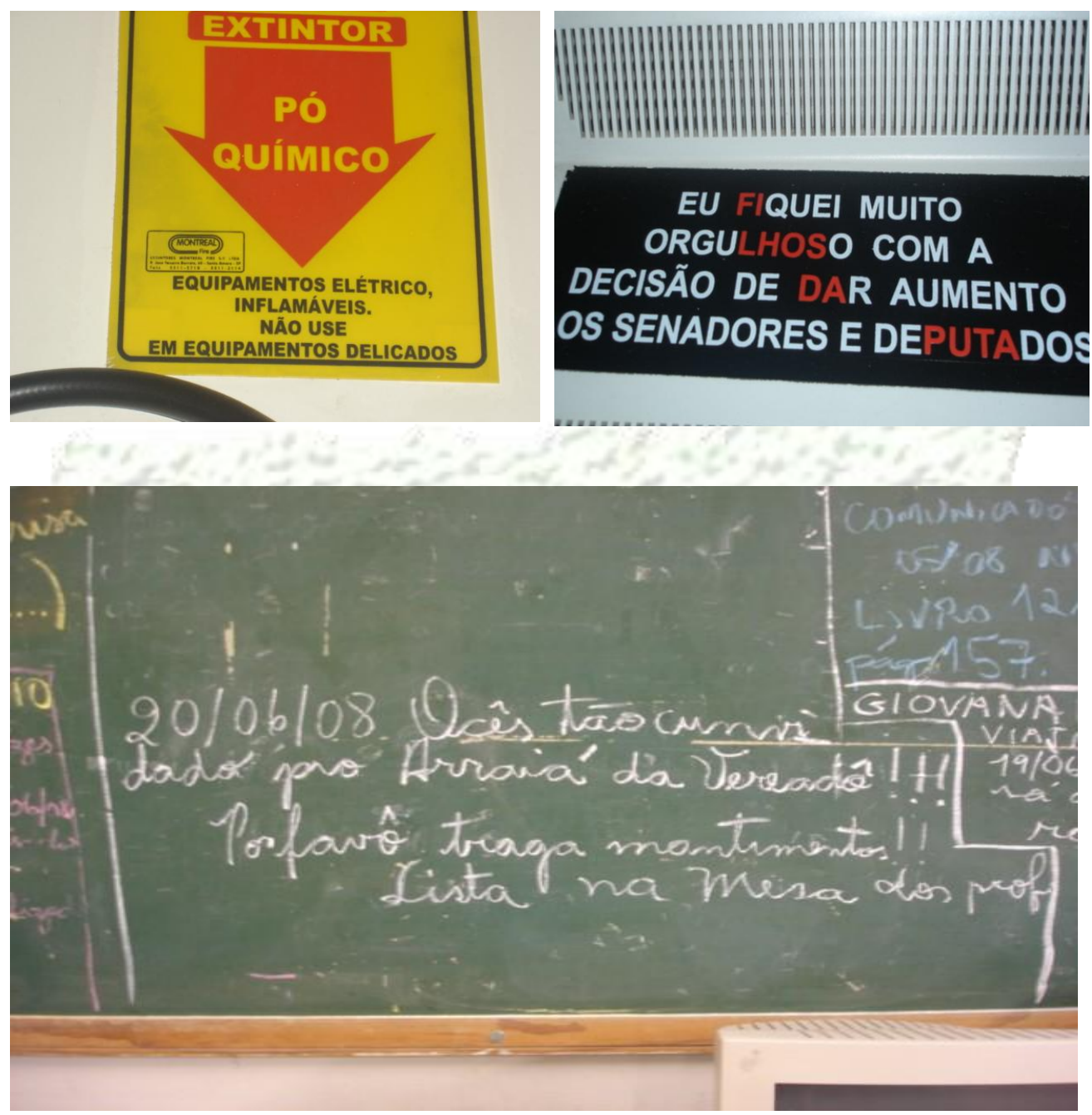

Parte II: Depoimentos dos participantes dos "espaços de criação" 


\section{Autora}

\section{Nilce da Silva}

Faculdade de Educação da Universidade de São Paulo

Contato: nilce_da_silva@hotmail.com ou nilce@usp.br

\section{Como citar este depoimento:}

SILVA, Nilce. Transposição didática e social: depoimentos e fotografias. Revista ACOALFAplp: Acolhendo a Alfabetização nos Países de Língua portuguesa, São Paulo, ano 3, n. 6, 2009. Disponível em: <http://www.acoalfaplp.net>. Publicado em: março 2009.

Recebido em setembro de 2008 / Aprovado em outubro de 2008

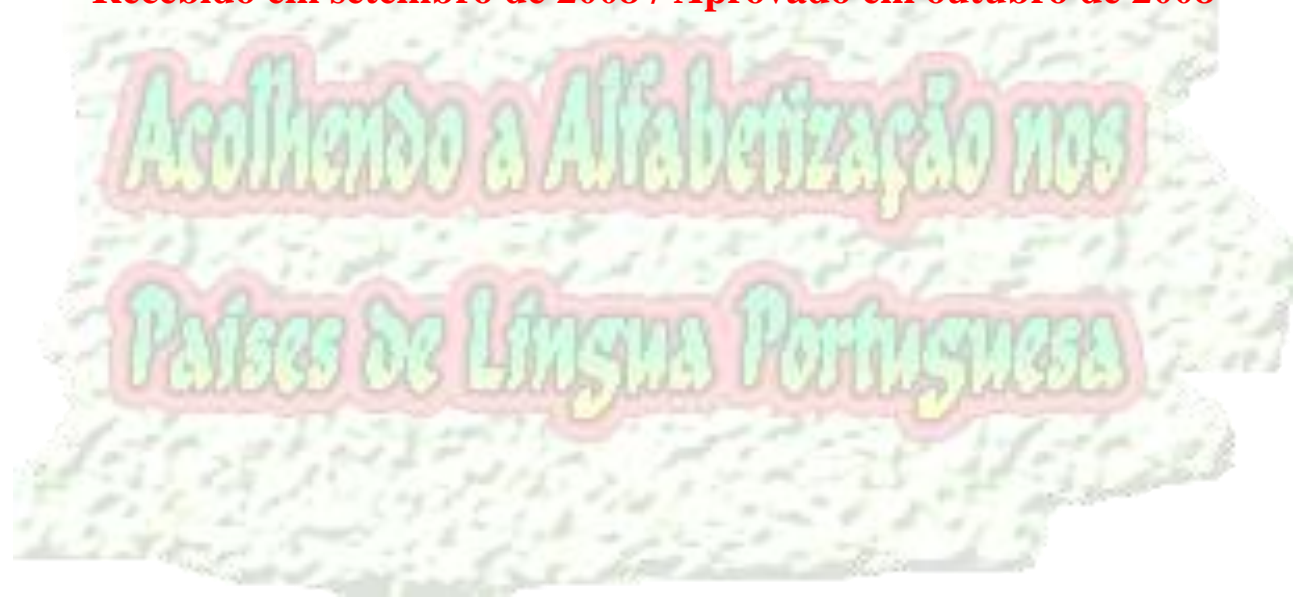

Sede da Edição: Faculdade de Educação da Universidade de São Paulo - Av da Universidade, 308 - Bloco A, sala 111 - São Paulo - SP 